\title{
Working
}

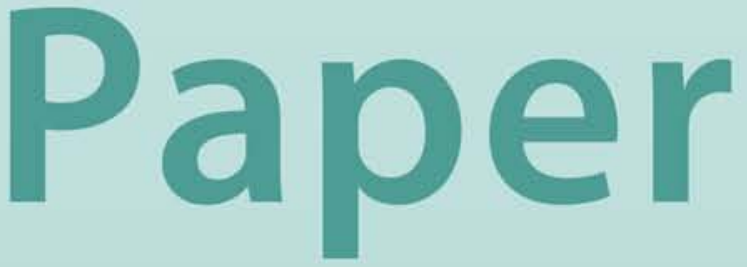




\section{On Target? The International Experience with Achieving Inflation Targets}

Scott Roger and Mark Stone 


\title{
IMF Working Paper
}

Monetary and Financial Systems Department

\section{On Target? The International Experience with Achieving Inflation Targets}

\author{
Prepared by Scott Roger and Mark Stone ${ }^{1}$ \\ Authorized for distribution by Peter Stella and Arne Petersen
}

August 2005

\begin{abstract}

\section{This Working Paper should not be reported as representing the views of the IMF.} The views expressed in this Working Paper are those of the author(s) and do not necessarily represent those of the IMF or IMF policy. Working Papers describe research in progress by the author(s) and are published to elicit comments and to further debate.
\end{abstract}

This paper examines the international experience with full-fledged inflation targeting monetary regimes. Stylized facts are brought together from a review of the institutional elements of inflation targeting frameworks, a comparison of actual and targeted inflation outcomes, and case studies of large inflation target misses. Inflation targets are missed about 40 percent of the time and often by substantial amounts and for prolonged periods, yet no country has dropped inflation targeting. The resilience of the inflation targeting regime is attributable to the flexibility of the framework, its high standards of transparency and accountability, and the lack of realistic alternatives.

JEL Classification Numbers: E52, E58, E61

Keywords: Inflation targeting, monetary policy

Author(s) E-Mail Address: sroger@imf.org; mstone@imf.org

\footnotetext{
1 This paper has benefited greatly from the comments and suggestions of many colleagues in the IMF and from central bank officials, to whom we are most grateful. Outstanding research assistance was provided by Sandra Marcelino. Errors and omissions remain the responsibility of the authors.
} 


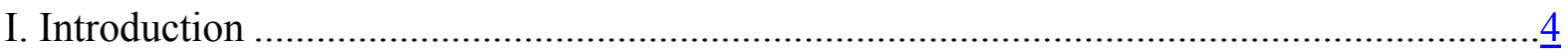

II. A Brief History of Full-Fledged Inflation Targeting ................................................

III. The Inflation Targeting Policy Framework …...................................................... 6

A. Inflation Target Parameters......................................................................

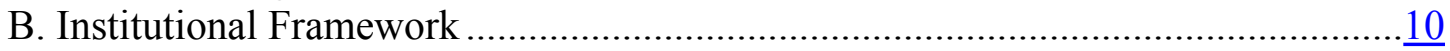

IV. Inflation Performance Under Inflation Targeting .............................................. 18

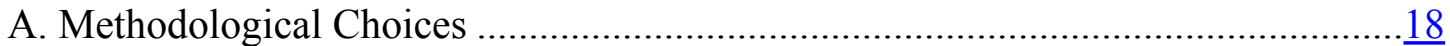

B. Aggregate Inflation Performance ................................................................ $\frac{19}{21}$

C. Inflation Performance Under Stable Inflation Targeting Versus Disinflation ......... 21

D. Inflation Performance In Industrial Countries Versus Emerging Market Economies

V. Selected Episodes of Large Misses of Inflation Targets .............................................29

VI. Stylized Facts of the Experience with Inflation Targeting ........................................

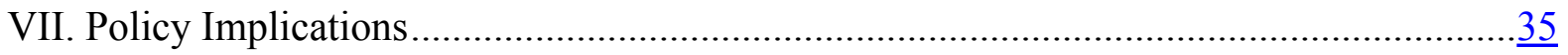

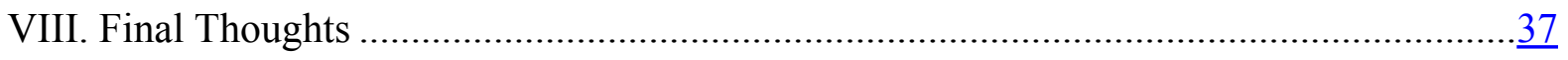

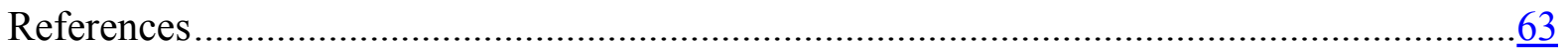

Tables

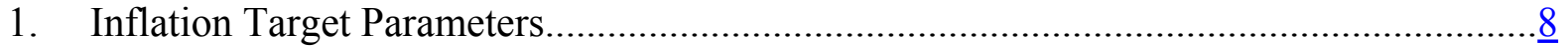

2. Monetary Policy Decision Making ........................................................................... $\frac{11}{11}$

3. Formal Procedures for Target Range Misses and Government Overrides ..................... $\underline{13}$

4. Monetary Policy Transparency Assessments Across Monetary Regimes ......................15

5. Transparency of Inflation Reports …................................................................ $\frac{16}{20}$

6. Inflation Outcomes Relative to Target or Center of Target Ranges .............................20

7. Inflation Outcomes Relative to Edges of Target Ranges........................................... $\frac{22}{23}$

8. Inflation Targeting Countries in Stable Inflation Stage .............................................23

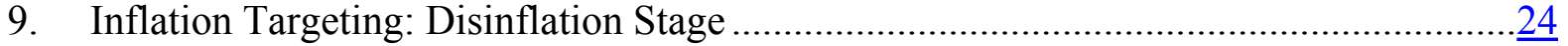

10. Deviation of Inflation from Target Ranges Groups of Countries ................................27

11. Evolution of Inflation Performances in Disinflation and Stable Target Stages...............29

12. Inflation Target Misses and Shocks ...................................................................... $\underline{30}$

Figures

1. Distribution of Inflation Outcomes Relative to Target ............................................25

2. Evolution of Inflation Outcomes ...................................................................... $\underline{28}$ 
Appendices

I. Detailed Tables on Inflation Outcomes ……….........................................................

II. Case Studies of Large Misses of Inflation Target Ranges............................................... 43

Appendix Tables

13. Disinflation Stage: Target Inflation Outcomes Relative to Center of Target Range .........39

14. Disinflation Stage: Deviations of Target Inflation from Target Range ………................ 40

15. Stable Inflation Target Stage: Target Inflation Outcomes Relative to Target

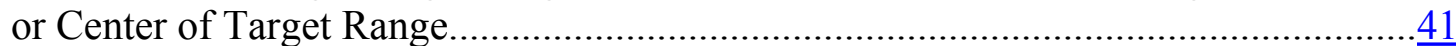

16. Stable Inflation Target Stage: Deviations of Target Inflation from Target Range ...........42

17. Brazil: Key Macroeconomic Indicators, 2001-2003 ……………..............................43

18. Czech Republic: Key Macroeconomic Indicators, 1999-2001 …………………......... 46

19. Iceland: Key Macroeconomic Indicators, 2000-2002 ….............................................

20. Israel: Key Macroeconomic Indicators, 1997-2003 ..................................................49

21. Poland: Key Macroeconomic Indicators, 1999-2003 …………………………….....

22. South Africa: Key Macroeconomic Indicators, 2001-2003 ……..................................55 


\section{INTRODUCTION}

Full-fledged inflation targeting is gaining popularity as a monetary regime. Inflation targeting is founded on a clear commitment to a quantitative inflation target as the primary objective of monetary policy, buttressed by a high degree of transparency and accountability in the formulation and implementation of policy. ${ }^{2}$

This paper analyzes the inflation experience of inflation targeting countries to develop stylized facts of their inflation performance and the implications for design of targeting frameworks. There does not yet appear to be a compendium of the now considerable experience with inflation targeting that can be used to guide the policies of practicing and prospective inflation targeters. Such guidance is especially important because an increasing number of developing and emerging market economies are considering adopting inflation targeting frameworks and these countries tend to face larger shocks and have more vulnerable economies.

The experiences of inflation targeting countries are examined here from three angles. First, the institutional framework is summarized with an emphasis on how frameworks have evolved. Second, inflation performances are compared with inflation targets in some detail. Third, case studies of the episodes of the largest misses of inflation targets are examined. The results from these approaches are then brought together in the form of stylized facts.

The evidence shows that inflation outcomes often deviate from targets by substantial margins and for prolonged periods. Countries targeting stable inflation miss the range about 30 percent of the time, while countries in the process of disinflation miss their target ranges nearly 60 percent of the time. Emerging market countries take longer to disinflate but have as good an inflation performance under stable inflation targeting as the industrial countries. The largest misses often reflect the direct and indirect impact of exchange rate shocks.

No country has dropped inflation targeting in response to misses, regardless of whether the misses are large, prolonged, or frequent. The resilience of inflation targeting appears to reflect the flexibility of the framework in handling shocks, high standards of transparency and accountability, as well as the lack of alternative monetary regimes.

Over the past 15 years, the transparency and accountability of inflation targeting frameworks have evolved. In most respects, the transparency aspects of the inflation targeting framework have tended to converge across countries. In particular, central banks now convey more information regarding their inflation forecasts and the reasons for and responses to misses of the target. The accountability aspects of the inflation-targeting framework are more countryspecific and less formal than the transparency aspects.

\footnotetext{
${ }^{2}$ Bernanke and others (1999), Mishkin and Schmidt-Hebbel (2001), and Truman (2003) provide broad reviews of full-fledged inflation targeting.
} 
The stylized facts have some significant policy implications. Inflation targeting central banks should not be surprised if they miss their target range around one-third of the time. Still, they should react to deviations of inflation from the center of the range well before inflation actually leaves it. The inflation target range should also take into account the country's economic characteristics, especially its vulnerability to exchange rate shocks. Finally, the experience of other inflation targeting countries provides a good guide for transparency modalities.

The paper is structured as follows. The next section examines the evolving monetary frameworks of inflation targeting countries, and Section III presents the details of the inflation targeting frameworks. Section IV analyses in detail the inflation performance under inflation targeting for 22 countries. Section V discusses the case studies of episodes of large deviations of inflation from the target range. The implications of the results of the three previous sections are integrated in Section VI, the policy implications are discussed in Section VII and Section VIII has some final thoughts. Detailed tables and case studies are in two appendices.

\section{A BRIEF HiSTORY OF FULL-FLEDGED INFLATION TARGETING}

This section provides a brief history of full-fledged inflation targeting to help motivate the subsequent analysis and put the results into perspective. Countries that practice full-fledged inflation targeting institutionalize a clear commitment to a quantitative inflation target. As detailed in the next section, the institutionalization of this commitment is in the form of communication vehicles that make the operations and intentions of policy transparent, and in many cases in formal means of holding the central bank accountable to meeting the target. ${ }^{3}$

The number of full-fledged inflation targeting countries now stands at 20. New Zealand pioneered inflation targeting in 1989 and today seven industrial countries employ this regime (Finland and Spain adopted the euro in 1999). Emerging market countries began to practice full-fledged inflation targeting in 1997 (Israel, which now is an industrial country and the Czech Republic) and thirteen use this regime currently. ${ }^{4}$ The per capita GDP of emerging

\footnotetext{
${ }^{3}$ There is broad agreement on which countries practice full-fledged inflation targeting (Truman, 2003; Bernanke and others, 1999; Schaechter and others, 2000; and Mishkin and Schmidt-Hebbel, 2001). Switzerland is a borderline case; it is not included here because the Swiss National Bank has gone to some lengths to say that it does not explicitly target inflation (SNB website).

${ }^{4}$ Masson and others (1997) cast a negative light on the adoption of inflation targeting by emerging market countries owing to institutional shortfalls. Mishkin (2000 and 2004a) is more positive but stressed the importance of developing supporting fiscal, financial, and monetary institutions. Schaechter and others (2000) documented the growing popularity of inflation targeting for emerging market countries and reported differences between emerging market countries and their advanced country and non-inflation targeting counterparts. Fraga and others (2003) concluded that emerging market countries face a more acute set of output and inflation volatility tradeoffs stemming from more pronounced external shocks, lower credibility, and lower levels of development of institutions. Transition countries are covered by Jonas and Mishkin (2003), who note
} 
market inflation targeting adopters has declined from US\$11,400 in 1997 (Czech Republic and Israel) to US\$1,500 in 2002 (Peru and the Philippines). In addition, a number of emerging market countries (e.g., Turkey, Romania, and Botswana) are moving toward full-fledged inflation targeting.

Full-fledged inflation targeting is set apart from other regimes by the inflation target nominal anchor and by the clarity of the commitment to this anchor. Exchange rate anchor regimes are clearly different. But full-fledged inflation targeting is also different from two other inflation-based regimes. First, there is what has been termed a "just do it" (Mishkin, 2000) or "implicit price stability anchor" (IPSA) regime (Carare and Stone, 2005), for example, the United States, the European Central Bank (ECB), and Switzerland. These countries have qualitatively less transparency and accountability but are able nevertheless to maintain low and stable inflation. The second regime is inflation targeting "lite," which is practiced by developing countries that also have an inflation objective but are unable, as opposed to unwilling, to maintain low and stable inflation (Stone, 2003).

Full-fledged inflation targeting is gaining popularity as a monetary regime. During the last decade and a half the share of large and developed countries with an exchange rate peg decreased from one-half to one-quarter of the total at the same time as the share of full-fledged inflation targeters rose from almost nil to one-quarter (Stone and Bhundia, 2004). ${ }^{5}$ To date, no country that has adopted full-fledged inflation targeting has subsequently been forced to abandon it.

Full-fledged inflation targeting also seems to be associated with improved overall economic performance. Corbo and others (2001), de Simone (2002) and $\mathrm{Hu}$ (2003) found that inflation targeting does not seem to entail much cost in terms of output volatility, while $\mathrm{Wu}$ (2004) concludes that inflation targeting results in lower and more stable inflation. In contrast, Ball and Sheridan (2003) conclude that inflation targeting has a limited independent effect on the inflation performance. Of course, it is essentially impossible to construct a counterfactual for countries that adopt inflation targeting, and this paper makes no attempt to do so.

\section{The Inflation Targeting Policy Framework}

The key elements of the inflation targeting framework are the governance structure, the specification of the inflation target, and the arrangements for policy transparency and accountability. These elements of the framework provide the central bank with the authority and incentives to pursue the inflation target. A central concern in the basic design of the

that these countries have missed inflation targets often by a large margin but have nevertheless progressed well with disinflation.

${ }^{5}$ The larger and more developed countries are those with GDP in 2000 exceeding US\$4 billion and/or per capita GDP greater than US\$720. 
framework is to minimize the time consistency problem by ensuring that good inflation performance is always the uppermost consideration in monetary policy formulation. At the same time, however, the framework must allow for the fact that the central bank's control over inflation is far from precise, for a wide range of reasons.

\section{A. Inflation Target Parameters ${ }^{6}$}

The numerical inflation target serves as the nominal anchor and makes possible a high degree of monetary policy accountability. Inflation target parameters vary across countries and to some degree across time, in the numerical specification of the inflation target, the time horizon over which the target is meant to be achieved, and the definition of the inflation measure being targeted.

\section{Numerical targets}

Most inflation targeting countries have adopted point targets within symmetric ranges for inflation outcomes (Table 1). Three countries have a point target, Australia has a "thick point" target one percentage point wide, and some others set a target range without specifying a point target. Some countries define a target range but do not specify a mid-point of the range as the official target. In a few cases, particularly during disinflation phases, countries have specified upper but not lower bounds to target inflation.

The levels and range widths for inflation targets are very similar across countries. With few exceptions, medium-term target levels for 12-month inflation rates are between 1 and 3 percent, and ranges are usually close to 2 percentage points wide (i.e., the target rate plus or minus 1 percentage point).

\section{Inflation target horizon}

The inflation target horizon is the period over which the central bank holds itself accountable for meeting its target. For the target to be meaningful, a basic requirement is that the horizon take into account the lags between policy actions and their effects on inflation outcomes. A policy horizon that is not as long as the lags associated with monetary policy transmission means that inflation over that horizon is largely beyond central bank control and, therefore, too short a horizon for meaningful targeting of inflation. Beyond the minimum meaningful policy horizon, a longer horizon can give the central bank more flexibility for taking other policy objectives into account without subordinating the inflation objective. Basically, a longer horizon allows the central bank more space to vary the pace of planned adjustment of inflation toward the central part of the target range.

\footnotetext{
${ }^{6}$ Detailed discussions of inflation target parameters can be found in Haldane (1995), Schaechter et al. (2000), and Castelnuovo and others (2003).
} 
Table 1. Inflation Target Parameters

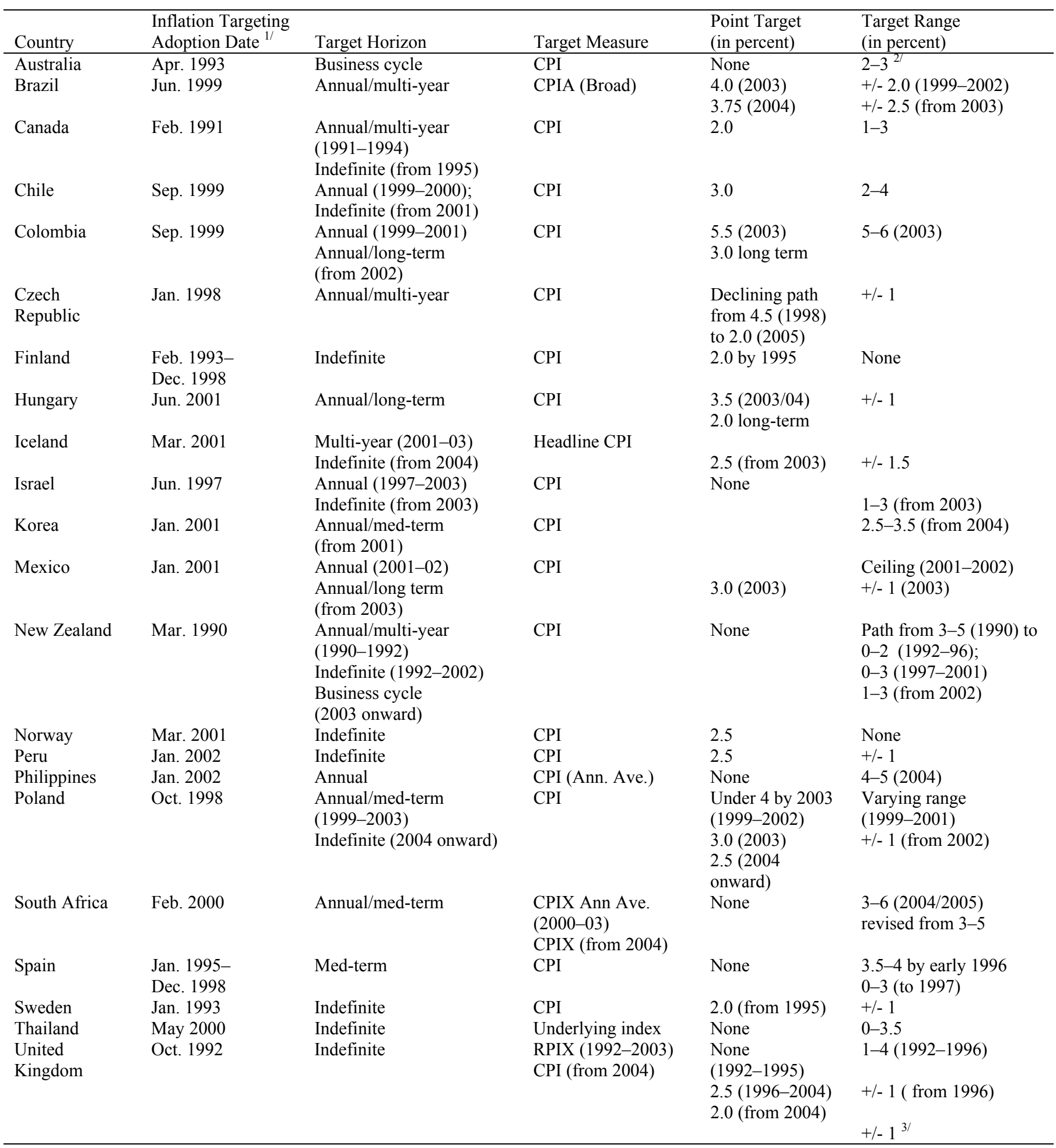

1/ Date of effective adoption of full-fledged inflation targeting. The dating of the adoption of full-fledged inflation targeting is mainly from Schaechter and others (2000), Mishkin and Schmidt-Hebbel (2001), and Truman (2003).

2/ Australia describes its target as a "thick point."

3 / Officially, there is not a range, but deviations of more than 1 percent from target requires an official explanation. 
Disinflating countries usually have finite, annual inflation target horizons (Table 1). At the advent of inflation targeting, disinflators usually indicate: (i) a long-term inflation objective, usually in numerical form, but sometimes only referring to typical inflation rates in a group of other countries, and (ii) a transition period - usually around three years or more-over which they aim to bring inflation down to the long-term target range. Annual targets are set at least one year into the future, and more commonly two years. In some cases, an entire path of annual targets through to achievement of the long-term objective is specified. Annual targets are usually defined in terms of the inflation rate over the 12 months to the end of calendar years. In a few cases, average annual inflation rates are used.

Target horizons tend to lengthen when inflation stabilizes. When inflation has been brought down into a range consistent with the long-term inflation objective, the annual inflation targets are replaced by a time-invariant or stable inflation target extending indefinitely into the future and which can be thought of as a long-run target. Even with the adoption of stable inflation targets, central banks still need to set their own effective planning horizons for policy. These horizons tend to lengthen as stable inflation is attained. Canada, Korea, New Zealand, and Sweden have explicitly extended their inflation target policy horizons since adopting full-fledged inflation targeting and other countries may well have done so less explicitly. Most inflation targeters appear to practice "flexible" inflation targeting, which requires a policy horizon long enough to capture the impact of monetary policy on inflation through movements in activity and output gaps.

\section{Inflation Target Index}

The target measure of inflation is based on the Consumers Price Index (CPI) in all inflation targeting countries (Table 1). Most countries define the target in terms of the official "headline" inflation rate. In some countries, however, the target measure has been defined to exclude interest costs. ${ }^{7}$ In a few others - Korea, Norway, and Thailand - the inflation target is been defined as a measure "core" or "underlying" inflation excluding the impact of various kinds of distortions, while other countries, e.g., Australia, Czech Republic, and New Zealand have moved away from specifying targets for core inflation. ${ }^{8}$

Core inflation measures continue to play key roles in policy formulation and accountability even if the target is defined in terms of headline inflation. Virtually all inflation targeters have developed and monitor various measures of core inflation. These measures are used in inflation forecasting and forward-looking policy formulation, as well as in ex post analysis of inflation developments both within the central banks and in the public accountability for inflation outcomes provided in their inflation reports.

\footnotetext{
${ }^{7}$ South Africa, Australia and New Zealand also excluded interest cost components of the CPI until CPIs were redefined to exclude these items. The United Kingdom also excluded interest costs (RPIX) until 2004 when the inflation target was switched to the CPI which does not include mortgage interest.

${ }^{8}$ See Roger (1998) for an overview of core inflation.
} 


\section{B. Institutional Framework}

The institutional framework for inflation targeting is designed to allow the public to monitor the forward-looking commitment of the central bank to the target. Central banks are usually designated by the government to operate an inflation targeting regime (goal dependence), but at the same time they have leeway in the implementation of monetary policy in support of the target (instrument independence) (Debelle and Fischer, 1994). The central bank policy decision makers are held accountable for implementing monetary policy in a manner consistent with achieving the target. Transparency of the intentions and operations of monetary policy is required for accountability to work.

\section{Governance structure}

Most inflation targeting central bank laws have price stability as the primary or sole de jure objective of monetary policy (Tuladhar, 2004). Only two countries have inflation targeting specified as the nominal anchor in the law. Some inflation targeting central banks, especially those with relatively old central bank laws, have objectives such as currency or monetary stability. No inflation targeting central banks have explicit objectives for the exchange rate, output growth, or financial stability.

The inflation target range is usually announced either by the government, or jointly by the government and the central bank (Tuladhar, 2004). The credibility of the inflation target may be enhanced by the government setting the target alone or with the central bank because this is perceived as strengthening the government's commitment to achieving the inflation objective, including through supportive fiscal policy measures. In contrast, some inflation targeting central banks can independently decide to adopt an inflation targeting regime and choose the target range.

Independence of the operation of monetary policy (instrument independence) is guaranteed in the legal frameworks of all inflation targeters (Schaechter and others, 2000). All emerging market countries established instrument independence in their central bank legislation prior to adopting an inflation targeting framework, while some of the industrial countries made changes after adopting inflation targeting.

\section{Monetary policy decision making}

In almost all inflation targeting countries, monetary policy decisions are made by a committee (MPC) within the central bank (Table 2). MPCs are the institutionalization of instrument independence. They reduce the dependence of decision making on a single personality and increase the scope for information-based decision making. In most cases, the committee is the same as the executive board or the board of governors. Most committees include a mix of central bank insiders and outsiders. 
Table 2. Monetary Policy Decision Making

\begin{tabular}{|c|c|c|c|c|c|c|}
\hline \multirow[b]{2}{*}{ Country } & \multirow{2}{*}{$\begin{array}{l}\text { Starting Date for } \\
\text { Inflation Targeting }\end{array}$} & \multirow{2}{*}{$\begin{array}{c}\text { Decision-Making } \\
\text { Body }\end{array}$} & \multicolumn{2}{|c|}{ Number of Members } & \multirow{2}{*}{$\begin{array}{l}\text { Frequency of } \\
\text { Meetings }\end{array}$} & \multirow{2}{*}{$\begin{array}{c}\text { Public Availability } \\
\text { of Records }\end{array}$} \\
\hline & & & Internal & External & & \\
\hline New Zealand & Mar. 1990 & Governor 1/ & $\ldots$ & 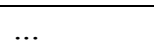 & & $\ldots$ \\
\hline Canada & Feb. 1991 & $\begin{array}{l}\text { Governing } \\
\text { Council }\end{array}$ & 6 & 0 & $\begin{array}{l}8 \text { times per } \\
\text { year }\end{array}$ & No \\
\hline $\begin{array}{l}\text { United } \\
\text { Kingdom }\end{array}$ & Oct. 1992 & $\begin{array}{l}\text { Monetary Policy } \\
\text { Committee } 2 /\end{array}$ & 5 & 4 & monthly & $\begin{array}{c}\text { Yes } \\
2 \text { weeks after }\end{array}$ \\
\hline Sweden & Jan. 1993 & Executive Board & 6 & 0 & $\begin{array}{l}8 \text { times per } \\
\text { year }\end{array}$ & $\begin{array}{c}\text { Yes } \\
2 \text { weeks after }\end{array}$ \\
\hline Australia & Apr. 1993 & $\begin{array}{l}\text { Reserve Bank } \\
\text { Board }\end{array}$ & 3 & 6 & monthly & No \\
\hline Israel & Jun. 1997 & Governor 1/ & $\ldots$ & $\ldots$ & $\ldots$ & $\ldots$ \\
\hline $\begin{array}{l}\text { Czech } \\
\text { Republic }\end{array}$ & Jan. 1998 & Bank Board & 7 & 0 & monthly & $\begin{array}{c}\text { Yes } \\
11 \text { days after }\end{array}$ \\
\hline Poland & Oct. 1998 & $\begin{array}{l}\text { Monetary } \\
\text { Council }\end{array}$ & 1 & 9 & monthly & $\begin{array}{c}\text { Yes } \\
6 \text { weeks after }\end{array}$ \\
\hline Brazil & Jun. 1999 & Executive Board & 8 & 0 & monthly & $\begin{array}{c}\text { Yes } \\
8 \text { days after }\end{array}$ \\
\hline Chile & Sep. 1999 & Executive Board & 2 & 3 & monthly & $\begin{array}{c}\text { Yes } \\
12 \text { weeks after }\end{array}$ \\
\hline Colombia & Sep. 1999 & $\begin{array}{l}\text { Board of } \\
\text { Directors }\end{array}$ & & & monthly & No \\
\hline South Africa & Feb. 2000 & $\begin{array}{l}\text { Monetary Policy } \\
\text { Committee }\end{array}$ & 8 & 0 & $\begin{array}{l}6 \text { times per } \\
\text { year }\end{array}$ & No \\
\hline Thailand & May 2000 & $\begin{array}{l}\text { Monetary Policy } \\
\text { Committee }\end{array}$ & 3 & 4 & 6 weeks & No \\
\hline Korea & Jan. 2001 & $\begin{array}{l}\text { Monetary Policy } \\
\text { Committee }\end{array}$ & 2 & 5 & monthly & $\begin{array}{c}\text { Yes } \\
6 \text { weeks after }\end{array}$ \\
\hline Mexico & Jan. 2001 & $\begin{array}{l}\text { Board of } \\
\text { Governors }\end{array}$ & 5 & 0 & daily & No \\
\hline Iceland & Mar. 2001 & $\begin{array}{l}\text { Board of } \\
\text { Governors }\end{array}$ & 3 & 0 & Does not apply & Does not apply \\
\hline Norway & Mar. 2001 & Executive Board & 2 & $4-6$ & 6 weeks & No \\
\hline Hungary & Jun. 2001 & $\begin{array}{l}\text { Monetary } \\
\text { Council }\end{array}$ & $4-6$ & $1-3$ & monthly & No \\
\hline Peru & Jan. 2002 & $\begin{array}{l}\text { Board of } \\
\text { Directors }\end{array}$ & 1 & 6 & monthly & No \\
\hline Philippines & Jan. 2002 & Monetary Board & 1 & 6 & weekly & $\begin{array}{c}\text { Yes } \\
1 \text { month after }\end{array}$ \\
\hline
\end{tabular}

Sources: Tuladhar (2004), Schmidt-Hebbel and Tapia (2002), and central bank websites.

1/ On advice of Monetary Policy Committee.

2/ Established after operational independence attained in 1997.

\section{Accountability}

Inflation targeting central banks are held accountable for their performance in relation to the targets. The "stakeholders" to whom the central bank is accountable can be viewed as comprising the public, the government, and the national legislative body. Typically, the central bank's performance is assessed on the basis of deviations of actual inflation outcomes 
from the target rate. Performance may also be assessed in a forward-looking manner, with the central bank being required to explain how it is managing policy in order to achieve future inflation outcomes consistent with the targets.

Target ranges play a key role in accountability. Standards of accountability typically vary according to whether inflation is inside or outside of the target range. When inflation is inside the target range, central banks provide a regular accounting for inflation outcomes and prospects in the inflation report-discussed in more detail in the next subsection - and any policy actions needed to keep inflation within the range. When inflation goes outside the target range, or is expected to do so, standards of accountability are usually tougher, with the central bank under much more pressure to explain whether a policy failure has been involved and what it proposes to do to bring inflation back within the range. The target ranges, therefore, act as an important threshold for policy accountability.

Accountability can be either formal or informal when the inflation target range is missed. In eight of the inflation targeting countries accountability arrangements include the requirement the central bank provide formal public explanations for inflation outcomes outside the target range (Table 3 ). In the other countries, accountability arrangements are less formal, but the central banks are still under pressure to explain significant deviations of inflation from the announced targets.

Some countries have used "escape" clauses in accountability arrangements, or set inflation targets in terms of core inflation to overcome some of the deficiencies of using target ranges as accountability thresholds. Escape clauses have been used to spell out in advance circumstances in which it may be appropriate for monetary policy to accommodate inflation disturbances. Typically these involve either adverse supply shocks or significant adjustments in administered or regulated prices. Setting the inflation target in terms of a measure of core inflation does essentially the same thing. These kinds of adjustments to accountability frameworks, however, have not become standard; indeed they have become less common over time. Canada, the Czech Republic, New Zealand, and South Africa seem to have been the only countries that have had escape clauses in their inflation targeting frameworks (Schaechter and others, 2001), and, as noted earlier, only a few countries set their targets in terms of core inflation.

The modes of accountability for inflation targeting central banks seem to be getting less formal. Early on there was talk of giving central bank governors financial incentives to keep inflation within the range but this approach was never used in practice. Nor have governors been fired for missing the range, although of course a bad performance could be taken into consideration when it comes time to renew their terms. All six of the first inflation targeting countries adopted some means of formal accountability, whereas only two of the most recent six adopters have formal accountability. 


\section{Table 3. Formal Procedures for Target Range Misses and Government Overrides}

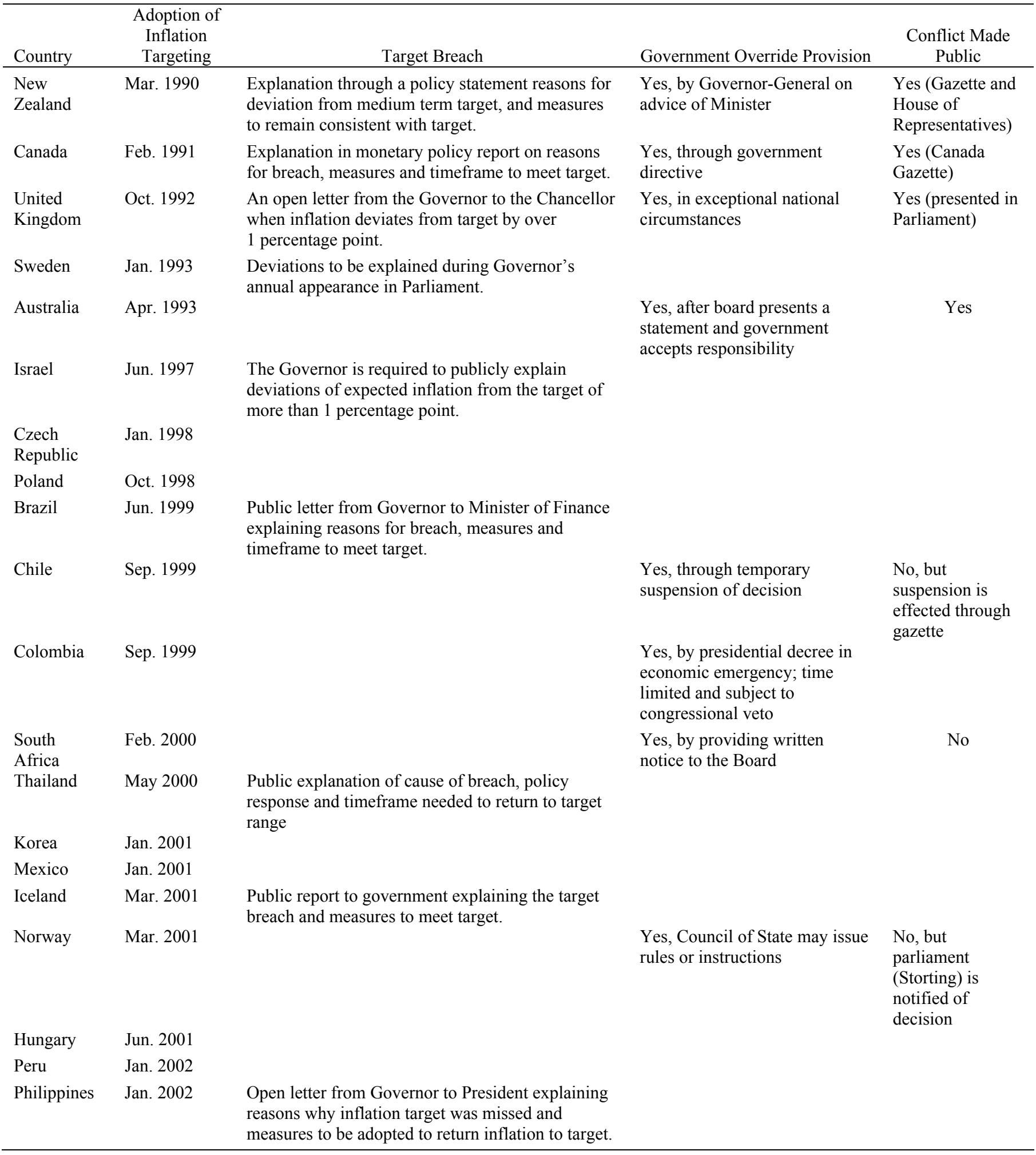

Sources: Tuladhar (2004) and central bank websites. 


\section{Transparency}

The operations and intentions of the central bank must be transparent in order for the stakeholders to hold the central bank accountable for its adherence to the inflation target. Under inflation targeting the central bank aims to maintain inflation and inflation expectations close to the target, but the lag between changes in the stance of monetary policy and inflation outcomes puts an onus on transparency and accountability so that the stakeholders can monitor the commitment of the central bank to adhering to the inflation target. Under an exchange rate regime transparency is less important because the commitment to the exchange rate can be monitored in real time. Transparency is also less important under an implicit price stability anchor because the central banks are less formally committed to maintaining price stability so that is less important to anchoring expectations.

For these reasons, full-fledged inflation targeting central banks are more transparent than other central banks that have looser inflation objective or use an exchange rate peg (Table 4). Ratings of central bank monetary policy transparency from country assessments of adherence to the IMF's Code of Monetary and Financial Policy Transparency indicate that full-fledged inflation targeting are more transparent in the conduct of monetary policy compared to central banks with implicit price stability anchor, inflation targeting lite, and exchange rate peg regimes. Interestingly, currency board/full dollarization central banks are about as transparent as full-fledged inflation targeting central banks perhaps reflecting the clarity of the objective. However, full-fledged inflation targeting countries have not been explicit about policy objectives other than inflation. ${ }^{9}$

For full-fledged inflation targeting countries transparency of the operation and rationale of the decisions of the monetary policy committee is crucial. Committee meetings for most inflation targeting central banks follow a prescheduled calendar (Schmidt-Hebbel and Tapia, 2002). Minutes in varying levels of detail are published by about half of the central banks, but only a few publish the votes of individual members (Table 2). All announce monetary policy actions in press releases and give press conferences explaining their actions. Some countries have senior central bank officials appear before parliamentary committees.

Over time, inflation reports have evolved to convey more information (Table 5). The early inflation targeters introduced inflation reports only after they committed to this regime. However, by the late 1990s central banks began to introduce an inflation report in preparation for the adoption of full-fledged inflation targeting. Other indications of the greater conveyance of information by inflation reports are the increase in the number of reports per year from an average of 2.7 in 1998 to 3.5 in 2004, and the rise in the share of

\footnotetext{
${ }^{9}$ The most explicit is the Bank of Norway which states "Norges Bank operates a flexible inflation targeting regime, so that weight is given to both variability in inflation and variability in output and employment."
} 
reports with a quantitative forecast of inflation from 75 percent on 1998 to 100 percent in 2004. Finally, the share of reports that included a fan chart of potential inflation outcomes increased from under one third in 1998 to over three quarters in 2004.

Table 4. Monetary Policy Transparency Assessments Across Monetary Regimes

Key Monetary and Financial Transparency Code Principles 1/ 2/

\begin{tabular}{lcccccc} 
& 1.1 .1 & 2.1 & 2.1 .1 & 2.3 .1 & 2.4 & 2.4 .1 \\
\hline & $\begin{array}{c}\text { Ultimate } \\
\text { Objectives } \\
\text { Specified in } \\
\text { Legislation }\end{array}$ & $\begin{array}{c}\text { Transparency } \\
\text { of Policy } \\
\text { Framework }\end{array}$ & $\begin{array}{c}\text { Transparency } \\
\text { of Policy } \\
\text { Operations }\end{array}$ & $\begin{array}{c}\text { Clarity of } \\
\text { Policy } \\
\text { Decisions }\end{array}$ & $\begin{array}{c}\text { Reporting on } \\
\text { Policy } \\
\text { Performance }\end{array}$ & $\begin{array}{c}\text { Reporting on } \\
\text { Policy } \\
\text { Objectives and } \\
\text { Assumptions }\end{array}$ \\
\hline $\begin{array}{c}\text { Full-fledged inflation } \\
\text { targeting (11) }\end{array}$ & 0.94 & 0.97 & 1.00 & 0.97 & 1.00 & 1.00 \\
$\begin{array}{c}\text { Implicit price stability } \\
\text { anchor (3) }\end{array}$ & 0.78 & 0.89 & 0.89 & 1.00 & 0.89 & 0.89 \\
$\begin{array}{c}\text { Inflation targeting lite } \\
\text { (14) }\end{array}$ & 0.74 & 0.67 & 0.71 & 0.59 & 0.86 & 0.76 \\
$\begin{array}{c}\text { Currency board/full } \\
\text { dollarization (5) }\end{array}$ & 1.00 & 1.00 & 0.80 & 1.00 & 0.87 & 1.00 \\
Exchange rate peg (10) & 0.77 & 0.77 & 0.89 & 0.74 & 0.48 & 0.82 \\
\hline Solnce: Stands & & & & & &
\end{tabular}

Source: Standards and Codes Gateway

Notes:

1.1.1-The ultimate objective(s) of monetary policy should be specified in legislation and publicly disclosed and explained.

2.1-The framework, instruments, and any targets that are used to pursue the objectives of monetary policy should be publicly disclosed and explained.

2.1.1-The procedures and practices governing monetary policy instruments and operations should be publicly disclosed and explained.

2.3.1-The central bank should publicly disclose, with a preannounced maximum delay, the main considerations underlying its monetary policy decisions.

2.4-The central bank should issue periodic public statements on progress toward achieving its monetary policy objective(s) as well as prospects for achieving them.

2.4.1-The central bank should periodically disclose its monetary policy objectives, quantitative targets, instruments, and the key underlying assumptions.

1/ Averages of assessments of each principle across countries in each regime. The assessments are scored as follows: $1=$ Fully Observed, $0.67=$ Broadly Observed, $0.33=$ Partly Observed, and $0=$ Not Observed; assessments of Not Applicable and Not Assessed are excluded.

2/ Number of assessed countries per regime in parentheses. 
Table 5. Transparency of Inflation Reports

\begin{tabular}{|c|c|c|c|c|c|c|c|c|c|c|c|c|c|c|}
\hline & \multirow{2}{*}{$\begin{array}{c}\text { Date of } \\
\text { Adoption of } \\
\text { Inflation } \\
\text { Targeting }\end{array}$} & \multirow{2}{*}{$\begin{array}{l}\text { Date of First } \\
\text { Inflation } \\
\text { Report }\end{array}$} & \multicolumn{4}{|c|}{ Number of Reports per Year } & \multicolumn{4}{|c|}{ Quantitative Forecast } & \multicolumn{4}{|c|}{ Fan Chart } \\
\hline & & & 1998 & 2000 & 2002 & 2004 & 1998 & 2000 & 2002 & 2004 & 1998 & 2000 & 2002 & 2004 \\
\hline New Zealand & Mar. 1990 & Apr. 1990 & 4 & 4 & 4 & 4 & Yes & Yes & Yes & Yes & No & No & No & No \\
\hline Canada & Feb. 1991 & May 1995 & 2 & 2 & 4 & 4 & Yes & Yes & Yes & Yes & No & No & No & No \\
\hline $\begin{array}{l}\text { United } \\
\text { Kingdom }\end{array}$ & Oct. 1992 & Mar. 1993 & 4 & 4 & 4 & 4 & Yes & Yes & Yes & Yes & Yes & Yes & Yes & Yes \\
\hline Sweden & Jan. 1993 & Oct. 1993 & 4 & 4 & 4 & 4 & Yes & Yes & Yes & Yes & Yes & Yes & Yes & Yes \\
\hline Australia & Apr. 1993 & May 1997 & 2 & 2 & 4 & 4 & Yes & Yes & Yes & Yes & No & No & No & No \\
\hline Israel & Jun. 1997 & Feb. 1998 & 1 & 2 & 2 & 2 & No & No & Yes & Yes & No & No & Yes & Yes \\
\hline Czech Republic & Jan. 1998 & Apr. 1998 & 3 & 4 & 4 & 4 & Yes & Yes & Yes & Yes & No & No & No & No \\
\hline Poland & Oct. 1998 & Jun. 1999 & & 4 & 4 & 4 & & No & No & Yes & & No & No & Yes \\
\hline Brazil & Jun. 1999 & July 1999 & & 4 & 4 & 4 & & Yes & Yes & Yes & & Yes & Yes & Yes \\
\hline Chile & Sep. 1999 & May 2000 & & 2 & 3 & 3 & & Yes & Yes & Yes & & Yes & Yes & Yes \\
\hline Colombia & Sep. 1999 & Jan. 1999 & & 4 & 4 & 4 & & Yes & Yes & Yes & & No & Yes & Yes \\
\hline South Africa & Feb. 2000 & Mar. 2001 & & $\ldots$ & 2 & 2 & & & No & No & & $\ldots$ & Yes & Yes \\
\hline Thailand & May 2000 & Jul. 2000 & & 2 & 4 & 4 & & Yes & Yes & Yes & & Yes & Yes & Yes \\
\hline Korea & Jan. 2001 & 1998 & & & 1 & 2 & & & Yes & Yes & & & Yes & Yes \\
\hline Mexico & Jan. 2001 & Mar. 1999 & & & 4 & 4 & & & Yes & Yes & & & No & No \\
\hline Iceland & Mar. 2001 & Nov. 1999 & & & 4 & 4 & & & Yes & Yes & & & Yes & No \\
\hline Norway & Mar. 2001 & Mar. 1996 & & & 3 & 3 & & & Yes & Yes & & & Yes & Yes \\
\hline Hungary & Jun. 2001 & Nov. 1998 & & 4 & 4 & 4 & & No & Yes & Yes & & No & Yes & Yes \\
\hline Peru & Jan. 2002 & Jun. 2002 & & & 2 & 3 & & & Yes & Yes & & & Yes & Yes \\
\hline Philippines & Jan. 2002 & Sep. 2001 & & & 4 & 4 & & & Yes & Yes & & & No & Yes \\
\hline
\end{tabular}

Sources: Schaechter and others, 2000; Wyplosz and others, 2003; central bank websites. 
Domestic money policy operations are highly transparent in all inflation targeting countries. Every inflation targeting central bank except for Mexico uses a short-term interest rate as its operating target and all use market-based instruments to set the policy interest rate (Carare and others, 2002). Central banks go to some length to explain how domestic monetary operations work. Further, changes in the interest rate target-which are almost always decided by the MPC - are announced and explained at the time of the change. Implicit price stability anchor countries also have highly transparent monetary operations (Borio, 1997), while inflation targeting "lite" central bank monetary operations are less transparent owing to their multiplicity of objectives (Stone, 2003).

In contrast, there is considerable variation in the transparency of foreign exchange market operations. Most smaller open inflation targeting countries, especially those with thin foreign exchange markets, intervene in the foreign exchange market or adjust interest rates to limit the effect of temporary exchange rate shocks on inflation and financial stability (Ho and McCauley, 2003). Australia (Rankin, 2001), and Sweden (Sveriges Riksbank, 2002) have explicitly described their approaches to foreign exchange operations to minimize confusion. Canada and New Zealand also explain the circumstances in which they would intervene, but have not intervened for many years. A few countries disclose information on intervention with a lag; for example, the United Kingdom discloses detailed information on intervention (e.g., amount, date, and reasons behind the intervention, and data on official foreign currency holdings) in a monthly press release. Brazil and Mexico implemented rules-based policies to signal their commitment to a market-determined exchange rate while at the same time accumulating reserves or supplying foreign exchange. However, several countries that implemented rules-based policies ultimately have abandoned or modified the rules to allow for discretion.

Practices also vary in the treatment of the interest rate path or assumption that underlies inflation forecasts. The reported interest rate path can be simply a constant, or based on market expectations, or it can be an endogenous path that keeps inflation close to the target. A few countries do not report an interest rate path at all. Most inflation forecasts have been based on a constant interest rate assumption although the trend may now be toward model-based paths. ${ }^{10}$

\footnotetext{
${ }^{10}$ As of 2003, twelve of the twenty inflation targeting central banks presented a constant interest rate path (Wyplosz and others, 2003). The evolving presentation of policy interest rates by the Central Bank of Chile over the past five years is typical: (i) a fixed policy rate for the first two years of the forecast, with judgmental adjustments on growth and inflation paths, (ii) a fixed policy rate for the first two years of the forecast with long rates and the exchange rate following a rule, and (iii) a fixed policy rate for a quarter, then a policy rule, with judgmental adjustments on growth and inflation paths (IMF, 2005).
} 


\section{INFLATION PERFormance UNDER INFLATION TARgETING}

This section examines the experience of full-fledged inflation targeting countries in achieving their targets. The analysis covers the aggregate experience of the 22 countries that have pursued full-fledged inflation targeting up to mid-2004 (including Finland and Spain in the mid and late 1990s).

\section{A. Methodological Choices}

Examination of actual versus targeted inflation requires a number of methodological choices. These are as follows:

- $\quad$ Country groupings: Countries are grouped into industrial and emerging market countries, and those with stable inflation targets and those pursuing disinflation, since the different circumstances of these groups suggests that they could have qualitatively different outcomes. The industrial countries are Australia, Canada, Finland, Iceland, Israel, Korea, New Zealand, Norway, Spain, Sweden, and the United Kingdom. The emerging market countries are Brazil, Colombia, Chile, Czech Republic, Hungary, Mexico, Peru, Philippines, Poland, South Africa, and Thailand. The statistics for stable and disinflating target countries cover the time periods when countries are pursuing unchanged or declining targets, respectively. Simple averages of statistics for countries for each group are used.

- $\quad$ Calculation of inflation targets: Individual country statistics are based on monthly (quarterly for Australia and New Zealand) differences between 12-month inflation rates and centers of target ranges. For countries that do not specify a point target the analysis presumes that the aiming point for policy is the center of the range in order to maximize the chances of staying within the range. For countries that set targets terms of year-end outcomes (mostly disinflators) and do not report monthly interpolations, the deviations of monthly outcomes from the year-end target are used.

- $\quad$ Core inflation: The official measure of core inflation is used, the definition of which varies across countries. In a few cases core and targeted inflation are the same.

- $\quad$ Starting point of inflation targeting regime: The dating of the start of inflation targeting stresses an unambiguous effective subordination of exchange rate objectives to the inflation target (Schaechter and others, 2000) and it corresponds quite closely to the "conservative" timing in Truman (2003), 


\section{B. Aggregate Inflation Performance}

The first set of results provides comparisons of the country groupings. These show some important differences between the groups.

\section{Inflation outcomes relative to target or center of target ranges}

Deviations of actual from the targeted inflation are substantial and vary considerably across country groups. The deviation has typically been about 1.8 percentage points, as measured by the root mean squared deviation of inflation from the mid-points of target ranges (Table 6 first column and Appendix Tables 13 and 15). Disinflating countries have experienced, on average, significantly greater dispersion of inflation outcomes around their targets than have countries with stable targets. An f-test of differences between the average mean squared error of deviations of inflation from target for disinflating and stable target countries rejected the null hypothesis of no significant difference at the 98 percent confidence level. Emerging market economies have, on average, experienced significantly greater dispersion of inflation around their targets than have industrial countries. An f-test of differences between the deviations of inflation from target for these two groups rejected the null hypothesis of no significant difference at the 96 percent confidence level. Essentially similar results are obtained using deviations of core inflation from target.

Disinflating countries tend to overshoot their targets and stable inflation countries undershoot, but the degree of bias is small in both cases (Table 6, second column). The average outcome for targeted inflation for all countries was just 0.1 percentage points above the center of target ranges, while the average outcome for core inflation was right on target. For countries in the process of disinflation, however, there has been a tendency toward over-shooting of targets, by an average of about 0.4 percentage points (Appendix Table 13), and an opposite tendency for countries pursuing stable inflation targets to under-shoot targets, by a similar margin (Appendix Table 15). A t-test of the difference in the means (assuming unequal variances) leads to rejection of the null hypothesis of no significant difference at the 93 percent confidence level for the target measure of inflation, and at the 90 percent level for core inflation. Smaller differences are evident between industrial and emerging market economies, and, further, the difference is not statistically significant.

The distribution of inflation outcomes closely resembles the normal distribution for most countries. The distribution of inflation outcomes has typically been fairly symmetric, even when the mean outcome has differed from the target, with slight positive skewness. The same pattern is seen with core inflation. There is also little evidence of excess kurtosis, indicating that the likelihood of extreme outcomes is approximately as would be expected in a normal distribution.

The volatility of inflation outcomes in most countries has been high relative to the width of their target ranges (Table 6 third column and Appendix Tables 13 and 15). The standard deviation of inflation outcomes relative to the center of target ranges averages 1.4 percentage points for the target measure of inflation, and only slightly less for core inflation. In 
comparison, the average width of target ranges is currently little more than 2 percentage points.

Table 6. Inflation Outcomes Relative to Target or Center of Target Ranges 1/

\begin{tabular}{|c|c|c|c|c|c|c|}
\hline & $\begin{array}{c}\text { Root Mean } \\
\text { Squared } \\
\text { Deviation } \\
\text { from Range } \\
\text { Center } \\
\text { (percentage } \\
\text { points) } \\
\end{array}$ & $\begin{array}{c}\text { Mean } \\
\text { Deviation } \\
\text { from Range } \\
\text { Center } \\
\text { (percentage } \\
\text { points) } \\
\end{array}$ & $\begin{array}{l}\text { Median } \\
\text { Deviation } \\
\text { from Range } \\
\text { Center } \\
\text { (percentage } \\
\text { points) } \\
\end{array}$ & $\begin{array}{l}\text { Standard } \\
\text { Deviation } \\
\text { Around Mean } \\
\text { Outcome } \\
\text { (percentage } \\
\text { points) } \\
\end{array}$ & $\begin{array}{l}\text { Skewness } \\
\text { Around } \\
\text { Mean } \\
\text { Outcome } \\
\end{array}$ & $\begin{array}{c}\text { Persistence } \\
\text { of Deviations } \\
\text { from Range } \\
\text { Center 2/ } \\
\text { (months) }\end{array}$ \\
\hline \multicolumn{7}{|c|}{ Target measure of inflation } \\
\hline All countries & 1.8 & 0.1 & -0.1 & 1.4 & 0.2 & 17.3 \\
\hline $\begin{array}{l}\text { Stable inflation } \\
\text { targets }\end{array}$ & 1.3 & -0.4 & -0.5 & 1.0 & 0.3 & 15.1 \\
\hline Disinflation targets & 2.2 & 0.4 & 0.1 & 1.7 & 0.3 & 16.3 \\
\hline Industrial countries & 1.3 & -0.2 & -0.3 & 1.1 & 0.3 & 15.5 \\
\hline $\begin{array}{l}\text { Emerging market } \\
\text { countries }\end{array}$ & 2.3 & 0.3 & 0.2 & 1.7 & 0.1 & 19.1 \\
\hline \multicolumn{7}{|l|}{ Core inflation } \\
\hline All countries & 1.7 & 0.0 & -0.1 & 1.3 & 0.2 & 19.4 \\
\hline $\begin{array}{l}\text { Stable inflation } \\
\text { targets }\end{array}$ & 1.1 & -0.4 & -0.5 & 0.8 & 0.5 & 16.1 \\
\hline Disinflation targets & 2.1 & 0.2 & 0.1 & 1.5 & 0.1 & 19.5 \\
\hline Industrial countries & 1.2 & -0.1 & -0.2 & 1.0 & 0.3 & 17.2 \\
\hline $\begin{array}{l}\text { Emerging market } \\
\text { countries }\end{array}$ & 2.2 & 0.0 & 0.0 & 1.5 & 0.1 & 21.5 \\
\hline
\end{tabular}

1/ Equally-weighted averages of corresponding statistics for individual countries in relevant groups. Individual country statistics are based on monthly (quarterly for Australia and New Zealand) differences between 12-month inflation rates and centers of target ranges.

2/ Persistence defined as the average number of months between changes in the sign of deviations of inflation from center of target range.

The persistence of deviations of inflation from target appears to be consistent with standard characterizations of monetary policy transmission lags. The measure of persistence reported in the sixth column of Table 6 and Appendix Tables 13 and 15 is simply the average length of time between changes in the sign of deviations of inflation from target. ${ }^{11}$ In effect, it indicates the amount of time needed, on average, for deviations of inflation from the center of the range to be reversed. Persistence is typically in the range of 16-20 months, which

\footnotetext{
${ }^{11}$ The measure is inspired by and very closely related to the persistence measure developed by Marques (2004). The measure of persistence used in this paper is equivalent to $T /(n+1)$ compared with Marques's measure of persistence: $\gamma=1-\frac{n}{T}$, where $T$ is the number of observations and $n$ is the number of times that the deviation of inflation from the target rate changes sign.
} 
corresponds fairly closely to the 6-8 quarters often referred to by central banks as the time it takes for changes in the stance of monetary policy to influence inflation. Deviations of inflation from target in emerging market or disinflating countries appears to be slightly more persistent than in industrial and stable inflation targeting countries.

\section{Inflation outcomes relative to edges of target ranges}

Inflation targeting countries have missed their target ranges, on average, over 40 percent of the time (Table 7 top panel first three columns and Appendix Tables 14 and 16). The frequency of target range misses is consistent with the evidence on the dispersion of inflation outcomes relative to the width of target ranges. Under-shooting of target ranges - around one-quarter of the time - is slightly more common than overshooting - around one-fifth of the time, but the average magnitudes of over- and under-shoots is the same. Misses of target ranges average a little over 8 months, with under-shoots typically a little longer than overshoots.

Performances in terms of core inflation have not been substantially different from those in terms of target inflation measures. As might be expected, deviations of core inflation from target tend to be more persistent than for the target measures of inflation (Table 7 bottom panel first three columns), and the slightly lower standard deviation of core inflation than of target inflation is reflected in less frequent misses of target ranges, but only by a very modest amount. These results largely reflect the fact that, for many of the countries, the target and core measures of inflation are (or were) the same. In addition, although there are typically fewer episodes of core inflation going outside the target range, those episodes typically last somewhat longer than for target inflation. ${ }^{12}$ As a result, the overall frequency of deviations from the target range is not very different for core inflation than for the target measure.

\section{Inflation Performance Under Stable Inflation Targeting Versus Disinflation}

As of mid-2004, 15 countries were pursuing stable inflation targets, and Finland and Spain had done so earlier (Table 8). Of the stable inflation targeters, 7 set stable long-term inflation targets at the time that they adopted full-fledged inflation targeting. Another 8 had previously pursued explicit disinflation targets within full-fledged inflation targeting frameworks.

\footnotetext{
${ }^{12}$ Indeed, this should be expected in so far as the aim of core inflation measures is generally to pick up the more persistent component of inflation associated with expectations and excess demand pressures.
} 
Table 7. Inflation Outcomes Relative to Edges of Target Ranges

\begin{tabular}{|c|c|c|c|c|c|c|c|c|c|}
\hline & \multicolumn{3}{|c|}{$\begin{array}{l}\text { Frequency of Deviations } \\
\text { (in percent) }\end{array}$} & \multicolumn{3}{|c|}{$\begin{array}{l}\text { Magnitude of Deviations } \\
\text { (percentage points) }\end{array}$} & \multicolumn{3}{|c|}{$\begin{array}{l}\text { Duration of Deviations } \\
\text { (in months) }\end{array}$} \\
\hline & Total & Below & Above & Average & Below & Above & Average & Below & Above \\
\hline \multicolumn{10}{|c|}{ Target measure of inflation } \\
\hline All countries & 43.5 & 24.2 & 19.3 & 1.2 & -1.2 & 1.2 & 8.3 & 9.2 & 7.0 \\
\hline $\begin{array}{l}\text { Stable } \\
\text { inflation } \\
\text { targets }\end{array}$ & 32.2 & 21.7 & 10.6 & 0.9 & -1.0 & 0.7 & 6.2 & 8.3 & 3.7 \\
\hline $\begin{array}{l}\text { Disinflation } \\
\text { targets }\end{array}$ & 59.7 & 27.7 & 2.0 & 1.4 & -1.3 & 1.4 & 9.9 & 10.3 & 9.0 \\
\hline $\begin{array}{l}\text { Industrial } \\
\text { countries }\end{array}$ & 34.8 & 22.5 & 12.3 & 0.9 & -0.8 & 1.0 & 8.2 & 8.8 & 7.3 \\
\hline $\begin{array}{l}\text { Emerging } \\
\text { market } \\
\text { countries }\end{array}$ & 52.2 & 25.9 & 26.2 & 1.4 & -1.5 & 1.4 & 8.3 & 9.7 & 6.8 \\
\hline \multicolumn{10}{|l|}{ Core inflation } \\
\hline All countries & 42.7 & & & 1.0 & & & 9.7 & & \\
\hline $\begin{array}{l}\text { Stable } \\
\text { inflation } \\
\text { targets }\end{array}$ & 28.9 & & & 0.7 & & & 7.8 & & \\
\hline $\begin{array}{l}\text { Disinflation } \\
\text { targets }\end{array}$ & 55.1 & & & 1.3 & & & 11.3 & & \\
\hline $\begin{array}{l}\text { Industrial } \\
\text { countries }\end{array}$ & 31.6 & & & 0.8 & & & 9.2 & & \\
\hline $\begin{array}{l}\text { Emerging } \\
\text { market } \\
\text { countries }\end{array}$ & 53.8 & & & 1.2 & & & 10.1 & & \\
\hline
\end{tabular}


Table 8. Inflation Targeting Countries in Stable Inflation Stage

\begin{tabular}{lccc}
\hline \multicolumn{1}{c}{ Country } & Stable Inflation Target Period & $\begin{array}{c}\text { Length of Stable } \\
\text { Inflation Targeting } \\
\text { (months) }\end{array}$ & $\begin{array}{c}\text { Inflation Target Rate1/ } \\
\text { (in percent) }\end{array}$ \\
\hline $\begin{array}{l}\text { Previous disinflation stage completed } \\
\text { Canada }\end{array}$ & & \\
Jan. 1995-Present & 114 & 2.0 \\
Czech Rep. & Jan. 2001-Present & 42 & 3.0 \\
Iceland & Jan. 2002-Present & 30 & 3.0 \\
Israel & Jan. 2004-Present & 6 & 2.5 \\
Mexico & Jan. 2003-Present & 18 & 2.0 \\
New Zealand & Jan. 2003-Present & 18 & 3.0 \\
Poland & Jan. 1993-Present & 138 & 2.0 \\
Spain & Jan. 2004-Present & 6 & 2.5 \\
Stable inflation target from outset & Jan. 1998-Dec. 1998 & 12 & 2.0 \\
Australia & Apr. 1993-Present & 135 & 2.5 \\
Finland & Feb. 1993-Dec. 1998 & 71 & 2.0 \\
Korea & Jan. 2001-Present & 42 & 3.0 \\
Norway & Mar. 2001-Present & 40 & 2.5 \\
Peru & Jan. 2002-Present & 30 & 2.5 \\
Sweden & Jan. 1993-Present & 138 & 2.0 \\
Thailand & 50 & 2.75 \\
United Kingdom & May 2000-Present & 141 & \\
Equally-weighted averages of countries in group & & \\
All countries & Oct. 1992-Present & 60.6 & 2.0 \\
Previous disinflation stage completed & 42.7 & 2.4 \\
Stable inflation target from outset & 80.9 & 2.3 \\
\hline
\end{tabular}

1/ Based on mid-points of target ranges unless otherwise indicated.

Five countries were pursuing explicit disinflation targets as of mid-2004 and another nine countries had completed disinflation (Table 9). For the countries that began inflation targeting with a transitional disinflation phase, it took an average of 41 months to reduce inflation to a stable rate within the inflation targeting framework. ${ }^{13}$ Disinflation typically involved a reduction of inflation of around 3 percentage points (not including the disinflation in the year that inflation targeting was initiated) over 3-4 years, so that planned reductions in targeted inflation averaged around $3 / 4$ percentage points per year.

\footnotetext{
${ }^{13}$ Several countries, including Chile, Israel, Mexico, and Peru, also pursued disinflation prior to adopting full-fledged inflation targeting.
} 
Table 9. Inflation Targeting: Disinflation Stage

\begin{tabular}{|c|c|c|c|c|}
\hline Country & Disinflation Period & $\begin{array}{l}\text { Length of } \\
\text { Disinflation } \\
\text { (months) }\end{array}$ & $\begin{array}{c}\text { Disinflation } \\
\text { Target } 1 / \\
\text { (percentage points) } \\
\end{array}$ & $\begin{array}{c}\text { Disinflation Rate } \\
\text { (percentage points } \\
\text { per year } 1 / \text { ) }\end{array}$ \\
\hline \multicolumn{5}{|c|}{ Disinflation completed } \\
\hline Canada & Feb. 1991-Dec. 1994 & 47 & -2.0 & -0.5 \\
\hline Chile & Sep. 1999-Dec. 2000 & 16 & -0.8 & -0.6 \\
\hline Czech Rep. & Dec. 1997-Dec. 2001 & 48 & -3.0 & -0.8 \\
\hline Iceland & Mar. 2001-Dec. 2003 & 34 & -1.0 & -0.4 \\
\hline Israel & Jun. 1997-Dec. 2002 & 67 & -6.5 & -1.2 \\
\hline Mexico & Jan. 2001-Dec. 2002 & 24 & -1.0 & -0.5 \\
\hline New Zealand & Mar. 1990-Dec. 1992 2/ & 36 & -3.0 & -1.0 \\
\hline Poland & Oct. 1998-Dec. 2003 & 63 & -5.5 & -1.4 \\
\hline Spain & Jan. 1995-Dec. 1997 & 36 & -2.3 & -0.8 \\
\hline \multicolumn{5}{|c|}{ Disinflation in progress } \\
\hline Brazil & Jun. 1999-Present & 61 & -2.5 & -0.5 \\
\hline Colombia & Sep.1999-Present & 58 & -9.0 & -1.9 \\
\hline Hungary & Jun. 2001-Present & 37 & -3.5 & -1.1 \\
\hline Philippines & Jan. 2002-Present & 30 & -1.0 & -0.4 \\
\hline South Africa & Feb. 2000-Present & 53 & -0.5 & -0.1 \\
\hline \multicolumn{5}{|c|}{ Equally-weighted averages of countries in group } \\
\hline All countries & & 43.6 & -2.9 & -0.7 \\
\hline Disinflation ce & & 41.2 & -2.7 & -0.7 \\
\hline Disinflation in & ress & 47.8 & -3.3 & -0.8 \\
\hline
\end{tabular}

1/ Based on mid-points of target ranges unless otherwise indicated.

2/ End of quarter.

Marked differences are evident in the dispersion of inflation outcomes between the two groups (Figure 1). For the stable inflation targeting group, the standard deviation of inflation relative to targets is nearly half that for the group of disinflating countries. The standard deviation of core inflation outcomes, as might be expected, is lower than for headline inflation in both groups. However, the differential in the dispersion of inflation outcomes between the two groups of countries is essentially the same for core and headline inflation. Ftests of the difference in the variances of inflation deviations from target between disinflating and stable inflation targeting countries rejected the null hypothesis of no significant difference at the 99 percent confidence level for both target and core inflation measures. 
Figure 1. Distribution of Inflation Outcomes Relative to Target

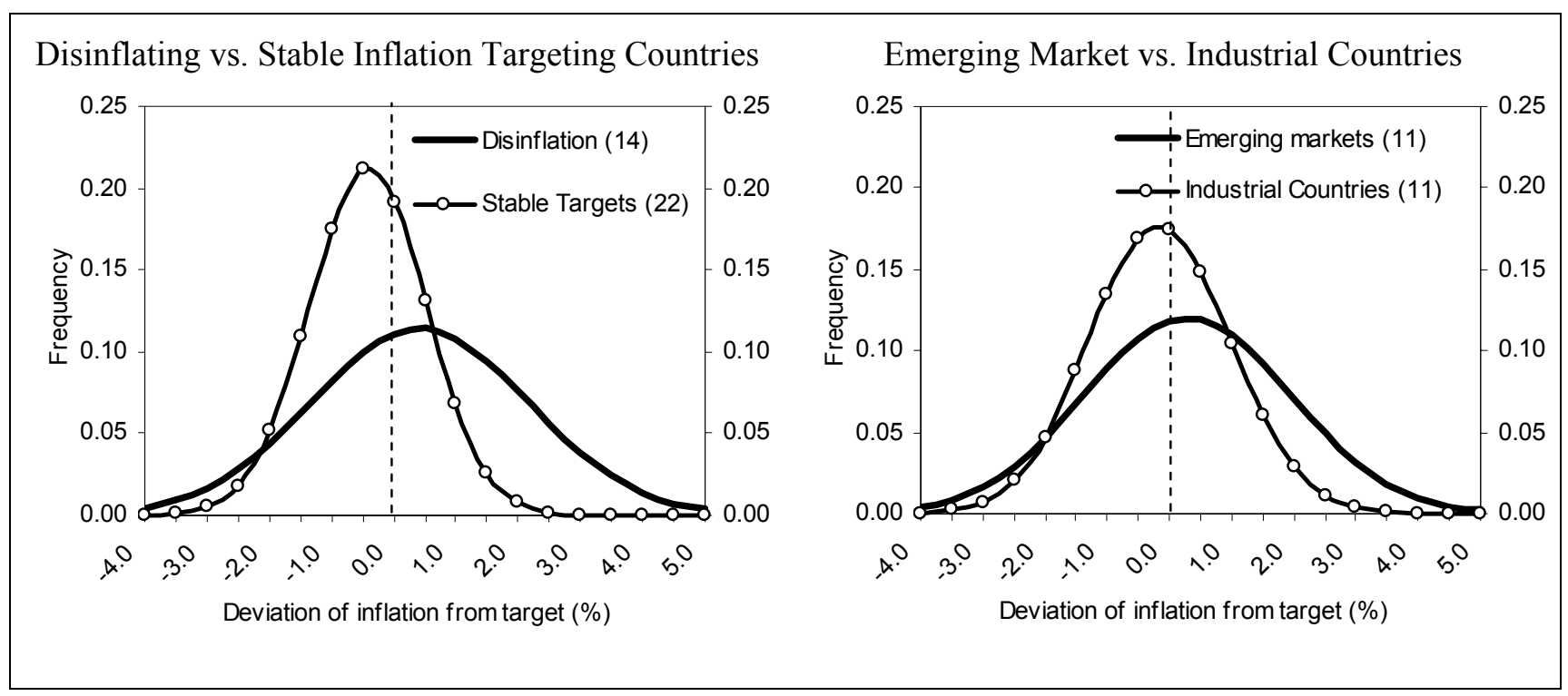

Moreover, disinflating countries have missed their target ranges, on average, twice as frequently as countries targeting stable inflation (Table 7). Given similar target range widths, but substantially greater dispersion of inflation outcomes, disinflating countries have missed their target ranges, on average, 60 percent of the time, compared with 32 percent of the time for countries with stable inflation targets. ${ }^{14}$ With less slightly lower dispersion in core inflation outcomes, misses of target ranges for these measures have been correspondingly less frequent, at 24 percent for stable inflation targeters and 56 percent for disinflators. In addition, while disinflating countries, on average, have tended to over-shoot target ranges only slightly less often than they under-shoot, stable inflation targeters are typically much more prone to under-shooting than over-shooting their target ranges. This is consistent with the earlier finding that median inflation outcomes for stable inflation targeters are typically in the lower part of the target range.

Disinflating countries have also tended to miss their targets by larger amounts, and for longer, than countries with stable inflation targets. Countries with stable inflation targets have missed their target ranges by an average of just under 1 percentage point, and for an average of about six months. For disinflating countries, misses of target ranges are typically on the order of 1.4 percentage points, with an average duration of nearly 10 months,

\footnotetext{
${ }^{14}$ In the case of the stable inflation targeters, assuming an average target range width of 2 percentage points, misses would occur 30 percent of the time if outcomes were normally distributed - nearly the same as actually observed. In the case of the disinflating countries, with an average target range width of 2.3 percentage points currently, and a standard deviation of inflation of 1.7 percentage points, misses of target ranges would occur 50 percent of the time, somewhat less than actually seen. For core inflation, the lower standard deviation would result in less frequent misses: a little over 20 percent of the time for stable inflation targeters and around 45 percent of the time for disinflators.
} 
significantly larger and longer than for stable inflation targeters. T-tests (assuming unequal variance) of differences between sample means for the magnitude and duration of deviations from target ranges for the stable inflation and disinflating countries reject the null hypothesis of no significant difference at the 95 percent confidence level in both cases. The duration of target range misses is fairly short, particularly for the stable inflation targeters, compared with lags typically associated with monetary policy actions. This, together with the earlier evidence on the persistence of deviations of inflation from the center of target ranges suggests that, in practice, central banks tend to respond to deviations of inflation from the center of target ranges well before inflation actually leaves the range. In other words, target ranges are not treated as zones of indifference, with action only triggered by movements of inflation outside the range.

\section{Inflation Performance In Industrial Countries Versus Emerging Market Economies}

Both emerging market and industrial countries have had average inflation outcomes quite close to target range centers and core inflation outcomes have been right on target. The standard deviation of inflation outcomes for emerging market economies, however, is significantly higher than for industrial economies, which is reflected in a substantial difference between the two groups in the average frequency of misses of their target ranges. F-tests of the difference in the variances of inflation deviations from target between industrial and emerging countries rejects the null hypothesis of no significant difference at the 89 percent confidence level for the target inflation measure and at the 90 percent level for core inflation.

Differences in inflation performance are more pronounced between disinflation and stable inflation than between emerging market and industrial countries (Table 10). Fairly consistently, the differences seen between emerging market and industrial country performances are smaller than those between disinflating countries and those targeting stable inflation. Moreover, when performances of emerging market and industrial countries are compared within the context of either disinflation or stable inflation targeting, differences are much smaller.

During the disinflation stage, both industrial and emerging market countries have experienced misses of target ranges nearly twice as often as during stable inflation targeting (Table 10). The magnitude of misses and is also significantly higher during disinflation for both groups of countries, and the duration of misses longer, indicating that this stage is difficult for all countries. Although emerging market economies have a higher frequency of target misses in both stages of inflation targeting than the industrial countries, the difference during the stable inflation targeting stage is quite small. The differences in performance seen between emerging market and industrial country groups as a whole substantially reflects the fact that the inflation targeting experience of emerging market economies has been predominantly in the disinflation stage - only a third have had any experience of stable inflation targeting, while the experience of industrial economies has been mainly in the stable inflation target stage - two-thirds have had experience of stable inflation targeting. 
Table 10. Deviation of Inflation from Target Ranges

\begin{tabular}{|c|c|c|c|c|c|c|c|c|c|}
\hline & \multicolumn{3}{|c|}{$\begin{array}{l}\text { Frequency of Deviations } \\
\text { (in percent) }\end{array}$} & \multicolumn{3}{|c|}{$\begin{array}{l}\text { Magnitude of Deviations } \\
\text { (percentage points) }\end{array}$} & \multicolumn{3}{|c|}{$\begin{array}{l}\text { Duration of Deviations } \\
\text { (in months) }\end{array}$} \\
\hline & Total & Below & Above & Average & Below & Above & Average & Below & Above \\
\hline \multicolumn{10}{|c|}{ Performance during stable inflation targeting } \\
\hline All countries & 32.2 & 21.7 & 10.6 & 0.9 & -1.0 & 0.7 & 6.2 & 8.3 & 3.7 \\
\hline Industrial countries & 28.6 & 21.0 & 7.5 & 0.9 & -0.9 & 0.7 & 7.4 & 9.2 & 4.6 \\
\hline $\begin{array}{l}\text { Emerging market } \\
\text { countries }\end{array}$ & 39.0 & 22.8 & 16.2 & 0.8 & -1.3 & 0.7 & 4.6 & 6.8 & 2.4 \\
\hline \multicolumn{10}{|c|}{ Performance during disinflation } \\
\hline All countries & 59.7 & 27.7 & 32.0 & 1.4 & -1.3 & 1.4 & 9.9 & 10.3 & 9.0 \\
\hline Industrial countries & 52.1 & 30.8 & 21.3 & 1.2 & -0.8 & 1.7 & 9.9 & 8.7 & 11.3 \\
\hline $\begin{array}{l}\text { Emerging market } \\
\text { countries }\end{array}$ & 63.9 & 26.0 & 38.0 & 1.4 & -1.6 & 1.3 & 9.9 & 11.3 & 7.9 \\
\hline
\end{tabular}

\section{Evolution of inflation performances}

The evolution of inflation performances over time also reveals important differences between stable inflation targeting and disinflation, and between emerging market and industrial countries. Figure 2 and Table 11 compare changes in inflation targeting performances over time of countries that are: (i) still in the process of disinflating (5 emerging market countries), (ii) countries that completed disinflation before moving to stable inflation targets ( 9 countries), and (iii) countries targeting stable inflation (17 countries). ${ }^{15}$ The analysis is limited to three years because, as indicated in Table 9, most countries complete the disinflation process within four years.

\footnotetext{
${ }^{15}$ These groups of countries are listed in Tables 8 and 9.
} 
Figure 2. Evolution of Inflation Outcomes

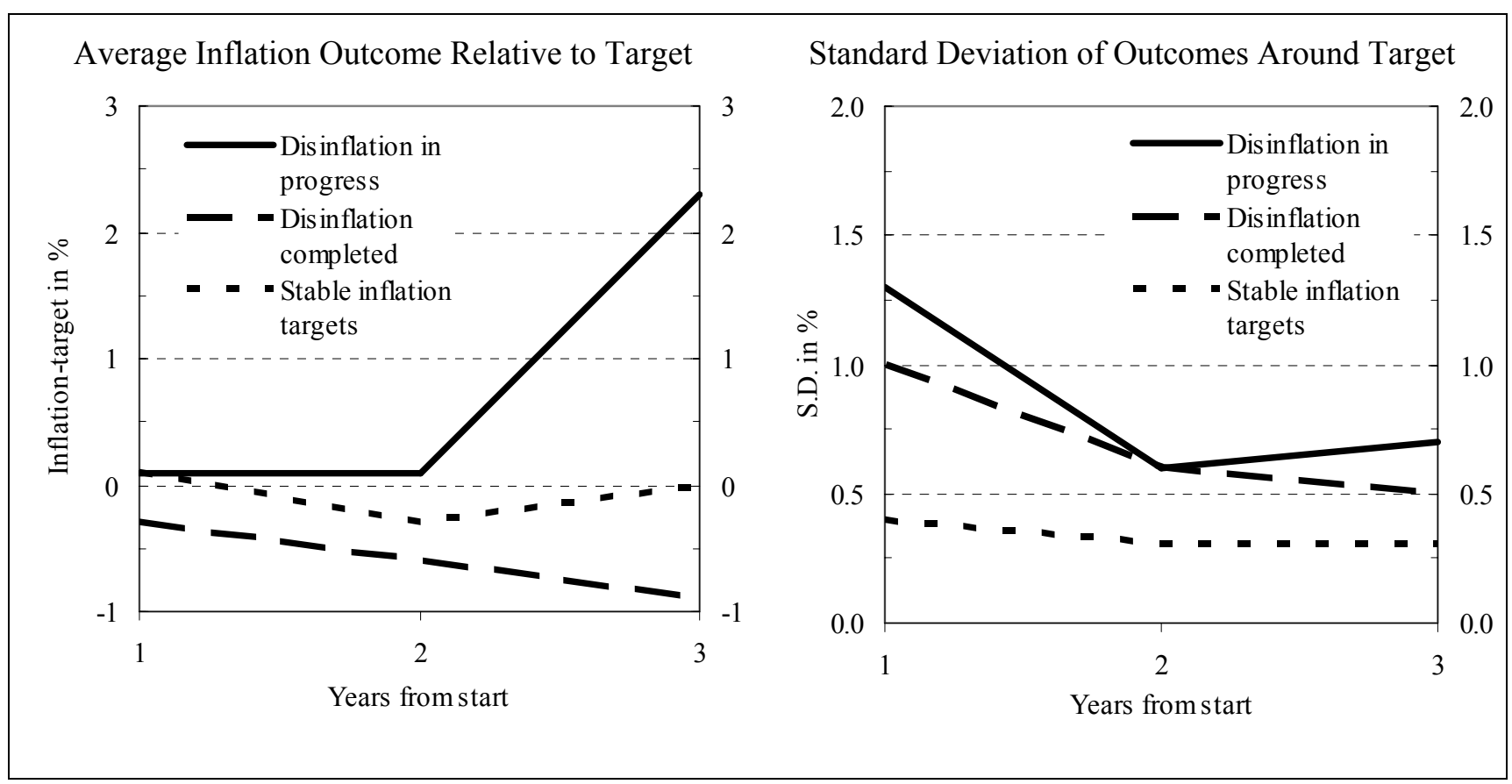

Countries with disinflation in progress have typically started out at a high level of inflation volatility but reduced it quickly (Table 11, first three columns). They start off with high volatility of inflation outcomes, as gauged by the root mean squared difference between actual and targeted inflation, but typically succeed in cutting volatility after the first year. Bias is insignificant during the first two years, while the sharp increase in the positive bias in the third year reflects the effects of the currency crises experienced in Brazil and South Africa, and should be regarded as a spurious outcome.

Countries that have completed disinflation have tended to undershoot their targets (Table 11, middle three columns). They demonstrated a downward bias during the first three years of disinflation. Further, volatility also starts off relatively high, but falls off quickly.

Countries targeting stable inflation from the outset show little change in performance over time (Table 11, last three columns). Inflation outcomes are typically close to the center of the range, without any clear trend, while the variability of inflation outcomes around the mean is typically low and stable. 
Table 11. Evolution of Inflation Performances in Disinflation and Stable Target Stages

\begin{tabular}{|c|c|c|c|c|c|c|c|c|c|}
\hline \multirow{2}{*}{$\begin{array}{c}\text { Years } \\
\text { from } \\
\text { Start of } \\
\text { Stage }\end{array}$} & \multicolumn{3}{|c|}{ Disinflation in Progress } & \multicolumn{3}{|c|}{ Disinflation Completed } & \multicolumn{3}{|c|}{ Stable Inflation Targets } \\
\hline & RMSE & $\begin{array}{c}\text { Bias } \\
2 / \\
\end{array}$ & $\begin{array}{c}\text { Variability } \\
3 /\end{array}$ & $\begin{array}{c}\text { RMSE } \\
1 /\end{array}$ & $\begin{array}{c}\text { Bias } \\
2 / \\
\end{array}$ & $\begin{array}{c}\text { Variability } \\
3 /\end{array}$ & $\begin{array}{c}\text { RMSE } \\
1 /\end{array}$ & $\begin{array}{c}\text { Bias } \\
2 / \\
\end{array}$ & $\begin{array}{c}\text { Variability } \\
3 /\end{array}$ \\
\hline 1 & 2.4 & 0.1 & 1.3 & 1.8 & -0.3 & 1.0 & 0.7 & 0.1 & 0.4 \\
\hline 2 & 2.0 & 0.1 & 0.6 & 2.5 & -0.6 & 0.6 & 0.5 & -0.3 & 0.3 \\
\hline 3 & 2.5 & 2.3 & 0.7 & 1.4 & -0.9 & 0.5 & 0.9 & 0.0 & 0.3 \\
\hline
\end{tabular}

1/ Median country value of root mean squared difference between 12-month inflation and target range center.

2/ Median country value of arithmetic average of difference between 12-month inflation and target range center.

3/ Median country value of standard deviation of difference between 12-month inflation and target range center.

\section{SELECTED EPISODES OF LARGE Misses OF INFLATION TARGETS}

Case studies of the largest misses of inflation targets are reviewed in this section. The frequency, magnitude and duration of misses of inflation targets reported in the previous section raise a host of questions. However, a comprehensive review of the causes and consequences of the misses is precluded by their large number and varying circumstances. This section looks at the most extreme misses because they have posed the biggest challenges to the inflation targeting regime and thus can provide some insights into how misses come about, how inflation is brought back into the range, and what are the longer-term consequences. Appendix I describes the episodes in detail.

The case study episodes were chosen based on the actual and targeted inflation rates described in the previous section. As noted before, misses of the inflation target ranges tend to be persistent. Thus, the under- and over-shootings of inflation target ranges were ranked based not on monthly data, but on three- and seven-month averages of the misses. The case studies are for the countries with the largest under- and over-shootings.

The selection of the eight largest inflation target miss episodes exhibits some interesting commonalities (Table 12). First, all of the countries are especially vulnerable to external shocks. Second, the largest deviations of inflation from target occurred during disinflation.

The misses were triggered by a mix of domestic and external shocks, as described in central bank and IMF reports. The most common shock was shifts in capital inflows brought on by changes in investor perceptions of emerging market risks. Changes in world fuel prices also played a role in two of the misses. Domestic shocks included changes in fiscal and monetary policies and the domestic food supply, and some country-specific developments.

All of the large misses reflected wide exchange rate fluctuations. These fluctuations included both depreciations and appreciations and manifest the openness of these countries on both current and capital accounts. 
None of the large misses led to an abandonment of the inflation targeting regime and institutional changes in response to misses have been fairly limited. Very large shocks and large misses in several cases did call into question the credibility of the monetary regime, but no countries dropped their commitment to the inflation target. The main change of the framework in response to a miss has been adjustments to the targets themselves.

Table 12. Inflation Target Misses and Shocks

\begin{tabular}{|c|c|c|c|c|c|c|c|c|c|}
\hline \multirow[b]{2}{*}{ Country } & \multirow[b]{2}{*}{ Miss } & & \multicolumn{3}{|c|}{ External Shocks } & \multicolumn{4}{|c|}{ Domestic Shocks } \\
\hline & & & $\begin{array}{l}\text { Capital } \\
\text { Flows }\end{array}$ & $\begin{array}{l}\text { World } \\
\text { Fuel } \\
\text { Prices }\end{array}$ & $\begin{array}{l}\text { Other } \\
\text { External }\end{array}$ & $\begin{array}{l}\text { Domestic } \\
\text { Food } \\
\text { Supply }\end{array}$ & Other Domestic & $\begin{array}{l}\text { Fiscal } \\
\text { Policy }\end{array}$ & $\begin{array}{l}\text { Monetary } \\
\text { Policy }\end{array}$ \\
\hline Brazil & Over & $2001-03$ & $\mathrm{x}$ & & & & $\begin{array}{l}\text { Controlled prices, } \\
\text { political risk }\end{array}$ & & \\
\hline Czech Rep. & Under & 1998-99 & & & & $\mathrm{x}$ & Retail competition & & \\
\hline Iceland & Over & 2002 & $\mathrm{x}$ & & & & Real wages & $\mathrm{x}$ & \\
\hline Israel & Under & 1998 & & & Immigration & & & $\mathrm{x}$ & $\mathrm{x}$ \\
\hline Israel & Under & $2001-02$ & $\mathrm{x}$ & & & & Productivity & & \\
\hline Israel & Over & $2002-03$ & $\mathrm{x}$ & & Intifada & & & $\mathrm{x}$ & $\mathrm{x}$ \\
\hline Poland & Over & 2000 & & $\mathrm{x}$ & & $\mathrm{x}$ & Taxes & & $\mathrm{x}$ \\
\hline Poland & Under & 2002 & & & & & Taxes & & \\
\hline South Africa & Over & $2002-03$ & $\mathrm{x}$ & $\mathrm{x}$ & $\begin{array}{l}\text { Regional } \\
\text { political risk }\end{array}$ & & & & \\
\hline
\end{tabular}

Sources: Central bank inflation reports, other central bank reports, IMF staff papers.

Inflation targeting countries in disinflation tend to take advantage of under-shooting of targets to accelerate the convergence to the long-term target rate, as detailed in the previous section. The authorities typically shift downward the planned trajectory for inflation in future periods rather than loosening policy in order to bring inflation back on the originally envisaged path.

The limited use of escape clauses in these episodes suggests that this element of inflation targeting frameworks has not proven to play an important role. The Czech central bank did not invoke escape clauses when inflation under-shot its target range. Further, South Africa started out with an escape clause in its framework in 1999 but seemed to have dropped it by the time of the over-shooting in 2002-03.

An absence of strong coordination between the fiscal and monetary authorities seems to have played a role in several large miss episodes. Misses in Israel and Poland seemed to be part of a negative dynamic whereby fiscal profligacy led to a tightening of monetary policy that according to the central bank would be loosened only in the event of fiscal consolidation. Meanwhile the negative monetary impulse increased the pressure for the fiscal authorities to loosen. All of this took place in the context of acrimonious public disagreements that could serve only to undermine the credibility of policy. In Poland the central bank is quite 
autonomous - it even has goal independence. By contrast, in Israel the government announces the inflation target, but the commitment to price stability is not buttressed by a supporting central bank law. The Czech Republic, where the government and the central bank agreed on a long-term monetary strategy in the context of accession to the European Union, exemplifies how good coordination can limit the adverse consequences of a miss.

Finally, the case studies demonstrate that two quite different approaches can be taken with respect to the inflation measure for which the central bank holds itself accountable. The Czech Republic switched from a core measure to headline CPI owing to wide fluctuations in food prices. Brazil has taken a different approach by defining an "adjusted" inflation target which effectively excludes inertia from lagged inflation and the primary effect of shocks to administered and monitored prices. Controlling for these two sources of inflation exogenous to monetary policy provides for accommodating the direct impact of shocks on inflation but countering the secondary effects.

\section{STYLIZED FACTS OF THE EXPERIENCE WITH INFLATION TARGETING}

This section summarizes the stylized facts of the experience with full-fledged inflation targeting. The previous sections focused on three different aspects of the inflation targeting experience: evolution of institutional frameworks, inflation performances, and episodes of large inflation target misses. This section brings together these three perspectives with a view to formulating stylized facts. The policy implications of these issues and trends are examined in the next section.

\section{Inflation targeting has proven to be flexible}

Inflation targeting central banks miss their targets frequently and often by a wide margin. In countries with stable inflation targets, target ranges are missed about 30 percent of the time, while disinflating countries miss the targets nearly 60 percent of the time. Yet, average outcomes over time tend to be fairly close to the center of target ranges. During the early days of inflation targeting there were concerns that this regime could be overly strict in the sense that central banks would aim to keep inflation within the range even at costs to other objectives. The results here suggest otherwise, supporting the view that "All real-world inflation targeting is flexible inflation targeting." (Svensson, 2005). The high degrees of transparency and accountability of inflation targeting regimes seem to give its practitioners scope or flexibility to miss their targets frequently and often by large margins or for lengthy periods without severely undercutting the credibility of the regime. Of course, flexibility requires that the supporting structural elements for price stability are in place, including a strong fiscal position.

\section{Inflation targeting regimes are resilient}

So far, no country has dropped an inflation targeting regime. Very large shocks and large misses in several cases have called into question the viability of the inflation targeting 
nominal anchor but in each episode the storm was weathered successfully. The absence of exits from inflation targeting stands in contrast to the record of conventional fixed exchange rate peg regimes and monetary targeting (Bubula and Otker-Robe, 2002; Stone and Bhundia, 2004). The resilience of inflation targeting likely reflects its operational flexibility which seems to reduce conflicts between adherence to the inflation target nominal anchor and output and financial stability. The case study countries may have found it easier to deal with their large misses because most were recent - all but two of the episodes occurred since 2000 - which allowed them to benefit from the accumulated experience with inflation targeting.

\section{Emerging market countries are successful practitioners of inflation targeting}

Emerging market countries have successfully adopted inflation targeting notwithstanding their greater vulnerabilities vis-à-vis industrial countries. ${ }^{16}$ Emerging market economies appear to have generally higher levels of inflation variability than industrial countries, even after disinflation has been achieved. Emerging market countries also seem to be more vulnerable to large misses than industrial countries. Still, the generally successful experience of emerging market countries with full-fledged inflation targeting shows that inflation targeting is a viable alternative to an exchange rate anchor given the right circumstances and policies.

\section{Disinflation from an inflation level around 10 percent is feasible under inflation targeting but inflation is more difficult to control}

The threshold level of inflation for adopting inflation targeting has been around 10 percent. Colombia, the Czech Republic, Hungary, Israel, and Poland began with inflation at or near double digits but on a declining trend, and only one country - Colombia - has had a target inflation range above 10 percent. The 10 percent threshold may indicate that monetary control is more difficult above that point. In addition, a decline of inflation into the single

\footnotetext{
${ }^{16}$ The main pertinent structural differences between inflation targeting emerging market countries and industrial countries appear to be in financial stability, exchange rate pass-through, and vulnerability to real shocks. Interestingly, current account openness of these two groups is about the same, while the industrial countries have more open capital accounts. Emerging market inflation targeting countries do have less developed financial systems and a higher incidence of financial crises, especially severe exchange rate crises resulting in large exchange rate depreciations (Schaechter and others, 2000). Indeed, inflation targeting emerging market countries can be constrained by "sudden stops" of capital inflows (Caballero and Krishnamurthy, 2003). Further, emerging market countries experience higher pass-through, apparently reflecting real exchange rate misalignments, higher rates of inflation, and greater output volatility (Goldfajn and Werlang, 2000). Interestingly, the emerging market inflation targeting countries generally have smaller fiscal deficits than their industrial country counterparts, although debt levels are higher (Schaechter and others, 2000). There has been much attention paid to the weaker institutional structures of emerging market countries (e.g., Masson and others, 1997 and Mishkin, 2000) but, as documented in Section III, in the area of monetary policy the institutional modalities of industrial and emerging market countries are quite similar. Finally, Agénor and others (1999) conclude that emerging market countries in general are more subject to large supply shocks than industrial countries.
} 
digits is an easily understandable signpost to the public for progress in disinflation that can help establish credibility for inflation targeting. Disinflation takes about $31 / 2$ years on average and inflation is reduced by about $3 / 4$ percent per annum.

However, inflation target misses are more frequent and larger for disinflating countries. Inflation volatility is quite high at the beginning of disinflation but is usually reduced quickly. Further, the countries that have completed disinflation have demonstrated a downward bias with actual outcome tending to fall below the (moving) target, consistent with the notion of opportunistic disinflation (Clifton, 1999).

Many inflation targeters had already begun to disinflate prior to adopting full-fledged inflation targeting under a more informal inflation targeting "lite" regime. They announced their intention to adopt full-fledged inflation targeting ahead of time thereby bringing forward some of the benefits of this more resolute nominal anchor to enhance the pace of disinflation (Stone, 2003). ${ }^{17}$

\section{In many respects the transparency elements of inflation targeting countries are converging}

In most respects the transparency aspects of the inflation targeting framework are converging across countries. All inflation targeting countries strive to attain a high degree of policy transparency via press releases, press conferences, and inflation reports, including increasingly quantitative macroeconomic forecasts.

Central banks are conveying more information regarding the inflation forecast and the reasons for and responses to misses of the target. As the inflation forecast has come to be viewed as the intermediate policy target, central banks have gone to greater lengths to make sure that the forecast is well understood, including through increases in the frequency of inflation reports, and in the publication of quantitative inflation forecasts and fan charts. ${ }^{18}$ Further, there are more detailed explanations of changes in the monetary stance and comprehensive backward-looking analyses of inflation and policy. The high degree of operational transparency may enhance the effectiveness of monetary policy by reducing the possibility of surprises in policy implementation and facilitate central bank independence. Like other central banks, inflation targeting central banks are less transparent with respect to foreign exchange intervention and financial stability policies.

\footnotetext{
${ }^{17}$ Carare and others (2002) discuss initial conditions for the adoption of full-fledged inflation targeting.

${ }^{18}$ Few central banks, however, have gone as far as publishing projections in which the path of interest rates and the exchange rate are consistent with achieving the inflation target. Typically, only a qualitative indication of the direction of policy is given. Fan charts of possible inflation outcomes are an increasingly standard feature of inflation reports, but are invariably based on unchanged interest rate and exchange rate assumptions, limiting their usefulness for most purposes.
} 
Some key aspects of inflation targeting transparency are still evolving

Inflation targeting central banks have not quantified policy objectives other than the inflation target. No inflation targeting central bank has explicitly articulated how it weighs price versus output stability as has been suggested in Svensson (2003, 2005). Further, the lengthening of policy horizons gives central banks more scope to attain output and financial stability objectives. This seems to make sense because it would be extremely difficult to design a monetary framework under which a central bank could be held accountable not just for an inflation target but also for output and financial stability objectives.

In addition, central banks generally remain reluctant to discuss their projections of the future path of interest rates or the exchange rate. Only a few countries provide a fairly explicit projection for policy variables (New Zealand being the most explicit). Most inflation targeting central banks believe that interest rate forecasts could cause confusion when subsequent events induce a change in the policy interest rate path from that forecasted (IMF, 2005). There is also the concern that disclosing interest rate assumptions would reveal the direction of policy and disrupt the market. However, a constant interest rate path may not be plausible or internally consistent (Mishkin, 2004b; Svensson, 2005).

\section{The modalities of accountability are more country-specific and less formal}

Accountability arrangements have become less formal over time. The use of escape clauses, setting of targets in terms of core inflation, and requirements for elaborate reporting on misses of inflation target ranges have become less common than in the early years of inflation targeting. The need for such arrangements may be reduced by maintaining a high degree of policy transparency. Indeed, such arrangements may not be particularly helpful in enhancing policy credibility or clarity.

The modalities of accountability vary more across countries compared to the inflation target specification or transparency elements of the framework. An important reason for this is that many elements of accountability are embedded in central bank laws and legal frameworks are more country-specific. Other aspects of accountability arise from particular events or circumstances - for example, a political crisis that shaped relations between different branches of the government- that are also highly country-specific.

The modalities of accountability also appear to be less readily modified than inflation targets and transparency. Countries change accountability arrangements less often than the other key elements of the inflation targeting framework, reflecting the difficulty in changing laws or established relations between different branches of the government. Another reason may be that changing how accountability is enforced could be seen as signaling a weakening of the commitment to the inflation target. The difficulty of changing accountability arrangements means that it is harder for countries to incorporate the lessons from the experience of other countries with inflation targeting. 
Central banks appear to respond to deviations of inflation from the center of target ranges, well before inflation actually leaves the range

The duration of target range misses is fairly short, particularly for the stable inflation targeters, compared with lags typically associated with monetary policy actions. This, together with the evidence on the persistence of deviations of inflation from the center of target ranges suggests that, in practice, central banks tend to respond to deviations of inflation from the center of target ranges prior to inflation actually leaving the range. In other words, target ranges are not treated as zones of indifference, with action only triggered by movements of inflation outside the range.

Most countries use headline CPI as the target measure of inflation, but continue to use core measures in policy analysis and communications.

Over time, inflation targeting countries are moving toward setting targets in terms of CPI inflation rather than core inflation. Perhaps the most important reason for this trend has been disillusionment with efforts to define measures of core inflation that are both readily explained to and accepted by the general public and at the same time satisfy more technical requirements (Ferreira and Petrassi, 2002). A second factor may also be the tendency for inflation targeters to focus on the relatively long policy horizons associated with flexible inflation targeting. As the policy horizon lengthens beyond the one year horizon, projections for headline and core inflation tend to converge, so that the distinction between the two loses significance in terms of external communication. Setting the target in terms of the measure of inflation most widely known greatly facilitates public communications and accountability, but does not preclude using core inflation measures in policy analysis. This approach also gives the central bank greater flexibility in deciding how to respond to particular kinds of price shocks in so far as it is not tied to one specific definition of core inflation, including its flaws. A particular problem in this regard has been that central banks targeting core inflation have typically used exclusion-based measures easily understood by the public, but not necessarily best for policy formulation (e.g., Marques and others, 2000). This kind of unhappy compromise is readily avoided by not elevating the core inflation measure to the status of formal target.

\section{Policy Implications}

This section discusses the practical policy implications for inflation targeting countries of the key issues and trends elaborated in the previous section. The discussion is aimed mainly at countries that are thinking about adopting inflation targeting, as well as current practitioners of inflation targeting that are refining their frameworks.

\section{Inflation targeting central banks can be expected to miss the target range}

Misses of targets are part and parcel of operating an inflation targeting monetary regime. This is quite different from exchange rate targeting. Of course, a balance must be struck such 
that misses do not impair policy credibility. Further, central banks should respond to deviations of inflation from the center of target ranges well before inflation actually leaves the range.

\section{The inflation targeting range should be specified taking into account a country's circumstances}

In particular, country-specific characteristics, especially vulnerability to exchange rate shocks, should be taken into account in setting target ranges. Failure to do so undermines the usefulness of the target ranges as either guides for expectations or as benchmarks for policy accountability. A target range that results in outcomes being outside the target range a high proportion of the time devalues the use of the ranges as a filter for distinguishing between normal and exceptional inflation developments and undercuts the usefulness of the range as a device for policy discipline within the central bank. Conversely, a range that is set wide relative to the normal variability of the country's inflation will provide too little discipline and too little accountability.

One approach to tailoring range widths to country characteristics could be to set target range widths to limit misses of target ranges to around one-third of the time. Stable inflation targeters have a standard deviation of inflation outcomes relative to targets close to 1 percentage point, which, given the approximately normal distribution of inflation outcomes and little bias in the mean, results in deviations of inflation outside the target range, on average, about one-third of the time. This approach would help maintain a reasonable balance between policy flexibility and policy discipline. At the practical level, the measure of volatility of inflation would necessarily be backward-looking and might be measured with reference to a moving average of actual inflation. Any such approach needs to be simple, and judgment would inevitably be called for in arriving at a final number.

In addition, the width of the target range should probably be narrowed over time. The evidence in this paper suggests that the volatility of inflation outcomes tends to decline quite rapidly after the start of inflation targeting. Thus, countries starting inflation targeting could begin with relatively wide ranges and then narrow the width progressively as they succeeded in bringing inflation volatility down, in much the same way as inflation targets themselves are lowered over time. The evidence on inflation volatility in this paper suggests that for most disinflating countries basing target range widths using a one-standard deviation rule would result in range widths of around 3-4 percentage points wide, narrowing to about 2 percentage points when stable inflation targets are adopted. This degree of narrowing should not be substantial enough to afford central banks enough extra room for maneuver to be able to subordinate the inflation target to other policy objectives.

The experience of other inflation targeting countries provides a good guide for transparency modalities

Inflation targeting countries have more or less converged to a common transparency framework. Only a few elements of transparency - in particular with respect to foreign 
exchange operations and the reporting of board meetings - diverge across countries. Thus, countries that are adopting full-fledged inflation targeting can build on the experience of their predecessors, especially with respect to inflation forecasts and presentation of the reasons for and responses to misses of the target.

Open economy countries must take account of their greater vulnerability to exchange rate shocks

This vulnerability is not due simply to being open but also reflects strong links between external shocks and domestic inflation. One set of links operates via the high rate of passthrough from the exchange rate to domestic inflation. This means that policymakers must pay special attention to the impact of exchange rate changes on inflation. Another set of links operates via the financial system and can kick in when external shocks raise financial vulnerability. This means that monetary policy must take account of potential financial sector problems when setting policy both because of the consequences for real stability and owing to the potential constraint on monetary policy posed by financial sector problems. An implication is that structural reforms are especially important to reduce the challenges posed to monetary policy by exchange rate vulnerabilities. Policies to strengthen financial stability would reduce the need for central bankers to take financial sector considerations into account in and of themselves. In this connection, maintaining a good degree of financial stability before adopting inflation targeting is important for the success of this regime.

\section{Final Thoughts}

This paper examined in some detail the inflation performance and monetary framework of countries operating under full-fledged inflation targeting regimes. Three different aspects of the inflation targeting experiences were examined: the evolution of institutional frameworks, inflation performances, and episodes of large inflation target misses.

Some common themes arise from the review of the experience with inflation targeting. The frequent and often large deviations from the inflation target range indicates that the inflation targeting regime is in practice flexible but also resilient: despite sometimes large misses, no country has dropped inflation targeting in favor of a different monetary policy framework. The transparency elements of the inflation targeting countries have more or less converged. In contrast, the accountability aspects are more country-specific. These common themes have important policy implications for inflation targeters and for countries thinking about adopting inflation targeting, as discussed in the previous section.

A core question raised by the paper is: what explains the resilience of the inflation targeting regime in the face of frequent and often large misses? These misses do not seem to reflect "bad" monetary policy; otherwise, the regime would surely have been abandoned or substantially modified. From an institutional perspective, this question can be answered by noting that the combination of legal and government support of the inflation target (goal dependence), the delegation of the operation of policy in support of the target (instrument 
independence), and accountability and transparency seem to have established a framework that allows the various "good" reasons for missing targets to be presented in a way that does not seriously undermine policy credibility, while providing adequate incentives for the central bank to seek to minimize "bad" reasons for missing targets.

Another way to answer this question is to note the lack of alternative regimes. If an inflation targeting central bank is struggling to adhere to the target, the markets will assess the alternative regimes that the central bank could consider. The alternative of an exchange rate peg is either not feasible (owing to capital account volatility or unstable money demand) or has unattractive properties (such as loss of monetary independence) for most countries, and monetary targeting is also likely to be viewed as an impractical alternative.

This review of the experience of inflation targeting also highlights some important issues on which the jury is still very much out. First, what are the limits of transparency under inflation targeting? Inflation targeting provides sufficient scope to allow the central bank to aim at objectives other than price stability (Mishkin, 2004b). But how does the central bank know when aiming for output or financial stability can threaten the credibility of its inflation target? The reporting of the interest rate path is another outstanding transparency issue.

Second, how does informal accountability work? The absence of formal accountability for many inflation targeting countries implies that informal means must hold sway, but these informal means are not well understood. The track record of inflation targeting countries indicates that central bankers have strong incentives for maintaining a credible regime. It may be that central bank governors and other monetary policy committee members care about their personal reputations with respect to the stakeholders to strive to keep inflation in the range and maintain the credibility of the central bank. Financial markets may enforce this accountability via asset price responses to central bank actions.

Finally, what is the minimal level of economic development for a country to adopt inflation targeting? The per capita GDP of new emerging market country adoptees of inflation targeting has been on the decline during the past 10 years, suggesting that the "bar is being lowered." Still, at some time in the not too distant future, a minimum threshold for the level of development needed for adopting inflation targeting will be reached. 


\section{Detailed Tables on Inflation Outcomes}

Table 13. Disinflation Stage: Target Inflation Outcomes Relative to Center of Target Range

\begin{tabular}{|c|c|c|c|c|c|c|}
\hline Country & $\begin{array}{c}\text { Root Mean } \\
\text { Squared } \\
\text { Deviation from } \\
\text { Range Center 1/ } \\
\text { (percentage } \\
\text { points) }\end{array}$ & $\begin{array}{c}\text { Mean } \\
\text { Deviation from } \\
\text { Range Center1/ } \\
\text { (percentage } \\
\text { points) }\end{array}$ & $\begin{array}{c}\text { Median } \\
\text { Deviation from } \\
\text { Range Center 1/ } \\
\text { (percentage } \\
\text { points) }\end{array}$ & $\begin{array}{c}\text { Standard } \\
\text { Deviation } \\
\text { Around Mean } \\
\text { Outcome 1/ } \\
\text { (percentage } \\
\text { points) }\end{array}$ & $\begin{array}{c}\text { Skewness } \\
\text { Around Mean } \\
\text { Outcomel/ }\end{array}$ & $\begin{array}{c}\text { Persistence of } \\
\text { Deviations } \\
\text { from Range } \\
\text { Center 2/ } \\
\text { (months) }\end{array}$ \\
\hline \multicolumn{7}{|c|}{ Disinflation completed } \\
\hline Canada & 1.7 & -0.8 & -0.9 & 1.5 & 0.9 & 23.5 \\
\hline Chile & 0.7 & 0.0 & 0.1 & 0.7 & -0.1 & 8.0 \\
\hline Czech Rep. & 2.8 & -1.4 & -1.4 & 2.5 & 0.0 & 26.0 \\
\hline Iceland & 3.0 & 1.7 & 0.4 & 2.5 & 0.6 & 11.3 \\
\hline Israel & 2.6 & -0.9 & -1.4 & 2.4 & 0.6 & 8.4 \\
\hline Mexico & 3.0 & 3.0 & 2.7 & 0.7 & 0.3 & 24.0 \\
\hline New Zealand & 0.9 & -0.8 & -0.8 & 0.6 & 0.0 & 36.0 \\
\hline Poland & 2.7 & -0.7 & -1.7 & 2.6 & 0.9 & 15.8 \\
\hline Spain & 0.7 & 0.0 & -0.1 & 0.7 & 0.3 & 9.0 \\
\hline \multicolumn{7}{|c|}{ Disinflation in progress } \\
\hline Brazil & 5.7 & 3.7 & 2.9 & 4.3 & 0.8 & 15.3 \\
\hline Colombia & 0.4 & -0.2 & 0.0 & 1.7 & -2.3 & 5.8 \\
\hline Hungary & 1.8 & 1.1 & 1.0 & 1.5 & 0.6 & 12.3 \\
\hline Philippines & 2.0 & -1.8 & -2.0 & 0.9 & 1.2 & 15.0 \\
\hline South Africa & 3.4 & 2.8 & 3.0 & 1.8 & 0.3 & 17.7 \\
\hline \multicolumn{7}{|c|}{ Aggregate indicators 3/ } \\
\hline All countries & 2.2 & 0.4 & 0.1 & 1.7 & 0.3 & 16.3 \\
\hline $\begin{array}{l}\text { Disinflation } \\
\text { completed }\end{array}$ & 2.0 & 0.0 & -0.3 & 1.6 & 0.4 & 18.0 \\
\hline $\begin{array}{l}\text { Disinflation } \\
\text { in progress }\end{array}$ & 2.7 & 1.1 & 1.0 & 2.0 & 0.1 & 13.2 \\
\hline $\begin{array}{l}\text { Industrial } \\
\text { countries } 4 /\end{array}$ & 1.8 & -0.1 & -0.6 & 1.5 & 0.5 & 17.6 \\
\hline $\begin{array}{l}\text { Emerging mar } \\
\text { countries 5/ }\end{array}$ & 2.5 & 0.7 & 0.5 & 1.8 & 0.2 & 15.5 \\
\hline
\end{tabular}

1/ Equally weighted averages of corresponding statistics for individual countries in relevant groups. Individual country statistics are based on monthly (quarterly for Australia and New Zealand) differences between 12-month inflation rates and centers of target ranges.

2/ Persistence defined as the average number of months between changes in the sign on deviations of inflation from center of target range.

3/ Equally weighted averages of countries in group

4/ Based on 1991-2001 average GDP/capita in U.S. dollar terms. Includes Canada, Iceland, Israel, New Zealand. and Spain.

5/ Based on 1991-2001 average GDP/capita in U.S. dollar terms. Includes Brazil, Chile, Colombia, Czech Republic, Hungary, Mexico, Philippines, Poland, and South Africa. 
Table 14. Disinflation Stage: Deviations of Target Inflation from Target Range

\begin{tabular}{|c|c|c|c|c|c|c|c|c|c|}
\hline \multirow[t]{2}{*}{ Country } & \multicolumn{3}{|c|}{$\begin{array}{l}\text { Frequency of Deviations } \\
\text { (in percent) }\end{array}$} & \multicolumn{3}{|c|}{$\begin{array}{l}\text { Magnitude of Deviations } \\
\text { (in percent) }\end{array}$} & \multicolumn{3}{|c|}{$\begin{array}{l}\text { Duration of Deviations } \\
\text { (in months) }\end{array}$} \\
\hline & Total & Below & Above & Average & Below & Above & Average & Below & Above \\
\hline \multicolumn{10}{|c|}{ Disinflation completed } \\
\hline Canada & 66.0 & 48.9 & 17.0 & 1.0 & -1.0 & 1.0 & 10.3 & 11.5 & 8.0 \\
\hline Chile & 12.5 & 6.3 & 6.3 & 0.2 & -0.2 & 0.2 & 1.0 & 1.0 & 1.0 \\
\hline Czech Rep. & 85.4 & 58.3 & 27.1 & 2.0 & -2.5 & 1.0 & 10.3 & 14.0 & 6.5 \\
\hline Iceland & 38.2 & 0 & 38.2 & 2.4 & .. & 2.4 & 13.0 & .. & 13.0 \\
\hline Israel & 73.1 & 55.2 & 17.9 & 2.0 & -1.8 & 2.7 & 9.8 & 9.3 & 12.0 \\
\hline Mexico & 75.0 & 0 & 75.0 & 0.6 & .. & 0.6 & 9.0 & .. & 9.0 \\
\hline $\begin{array}{l}\text { New } \\
\text { Zealand }\end{array}$ & 33.3 & 33.3 & 0 & 0.4 & -0.4 & .. & 12.0 & 12.0 &.. \\
\hline Poland & 85.7 & 60.3 & 25.4 & 1.9 & -1.6 & 2.6 & 13.5 & 19.0 & 8.0 \\
\hline Spain & 50.0 & 16.7 & 33.3 & 0.4 & -0.2 & 0.6 & 4.5 & 2.0 & 12.0 \\
\hline \multicolumn{10}{|c|}{ Disinflation in progress } \\
\hline Brazil & 63.9 & 4.9 & 59.0 & 3.3 & -1.5 & 3.4 & 13.0 & 3.0 & 18.0 \\
\hline Colombia & 15.7 & 13.8 & 1.9 & 1.1 & -2.5 & 0.3 & 2.8 & 4.0 & 2.3 \\
\hline Hungary & 45.9 & 0 & 45.9 & 1.4 & & 1.4 & 5.7 & & 5.7 \\
\hline Philippines & 93.3 & 90.0 & 3.3 & 1.5 & -1.6 & 0.1 & 14.0 & 27.0 & 1.0 \\
\hline South Africa & 75.5 & 0 & 75.5 & 2.1 & & 2.1 & 20.0 & & 20.0 \\
\hline \multicolumn{10}{|c|}{ Aggregate indicators $^{1 /}$} \\
\hline All countries & 59.7 & 27.7 & 32.0 & 1.2 & -1.3 & 1.4 & 9.9 & 10.3 & 9.0 \\
\hline $\begin{array}{l}\text { Disinflation } \\
\text { completed }\end{array}$ & 57.7 & 31.0 & 26.7 & 1.0 & -1.1 & 1.4 & 9.3 & 9.8 & 8.7 \\
\hline $\begin{array}{l}\text { Disinflation } \\
\text { in progress }\end{array}$ & 63.3 & 21.7 & 41.6 & 1.6 & -1.8 & 1.5 & 11.1 & 11.3 & 9.4 \\
\hline $\begin{array}{l}\text { Industrial } \\
\text { countries }^{2 /}\end{array}$ & 52.1 & 30.8 & 21.3 & 1.2 & -0.8 & 1.7 & 9.9 & 8.7 & 11.3 \\
\hline $\begin{array}{l}\text { Emerging } \\
\text { Market } \\
\text { countries }^{3 /}\end{array}$ & 63.9 & 26.0 & 38.0 & 1.4 & -1.6 & 1.3 & 9.9 & 11.3 & 7.9 \\
\hline
\end{tabular}

1/ Equally-weighted averages of countries in group

2/ Based on average 1991-2001 average GDP/capita in U.S. dollar terms. Includes Canada, Iceland, Israel, New Zealand. and Spain.

3/ Based on average 1991-2001 average GDP/capita in U.S. dollar terms. Includes Brazil, Chile, Colombia, Czech Republic, Hungary, Mexico, Philippines, Poland, and South Africa. 
Table 15. Stable Inflation Target Stage: Target Inflation Outcomes Relative to Target or Center of Target Range

\begin{tabular}{|c|c|c|c|c|c|c|}
\hline Country & $\begin{array}{c}\text { Root Mean } \\
\text { Squared } \\
\text { Deviation from } \\
\text { Range Center }^{1 /} \\
\text { (percentage } \\
\text { points) }\end{array}$ & $\begin{array}{c}\text { Mean } \\
\text { Deviation } \\
\text { from Range } \\
\text { Center 1/ } \\
\text { (percentage } \\
\text { points) } \\
\end{array}$ & $\begin{array}{c}\text { Median } \\
\text { Deviation from } \\
\text { Range Center 1/ } \\
\text { (percentage } \\
\text { points) }\end{array}$ & $\begin{array}{c}\text { Standard } \\
\text { Deviation } \\
\text { around Mean } \\
\text { Outcome 1/ } \\
\text { (percentage } \\
\text { points) } \\
\end{array}$ & $\begin{array}{c}\text { Skewness } \\
\text { around Mean } \\
\text { Outcome 1/ }\end{array}$ & $\begin{array}{c}\text { Persistence of } \\
\text { Deviations } \\
\text { from Range } \\
\text { Center 1/ } \\
\text { (months) } \\
\end{array}$ \\
\hline \multicolumn{7}{|c|}{ Disinflation completed } \\
\hline Canada & 0.9 & 0.0 & 0.0 & 0.9 & 0.6 & 11.4 \\
\hline Chile & 1.3 & -0.4 & -0.1 & 1.3 & -0.8 & 10.5 \\
\hline Czech Rep. & 2.8 & -2.4 & -3.1 & 1.4 & 0.4 & 15.0 \\
\hline Iceland & 0.7 & 0.1 & -0.2 & 0.8 & 1.0 & 2.0 \\
\hline Israel & 3.4 & -2.0 & -3.3 & 2.8 & 1.1 & 9.0 \\
\hline Mexico & 1.6 & 1.5 & 1.3 & 0.5 & 1.2 & 18.0 \\
\hline New Zealand & 0.9 & 0.5 & 0.5 & 0.8 & -0.4 & 17.3 \\
\hline Poland & 1.1 & 0.0 & -0.5 & 1.2 & 1.1 & 3.0 \\
\hline Spain & 0.4 & -0.2 & -0.2 & 0.3 & 0.1 & 4.0 \\
\hline \multicolumn{7}{|c|}{ Stable inflation target from outset } \\
\hline Australia & 0.7 & -0.2 & -0.1 & 0.6 & -0.1 & 27.0 \\
\hline Finland & 1.4 & -1.1 & -1.1 & 0.9 & 0.5 & 35.5 \\
\hline Korea & 0.4 & 0.2 & 0.1 & 0.4 & 0.9 & 10.5 \\
\hline Norway & 1.2 & -0.8 & -0.5 & 1.0 & -0.6 & 4.4 \\
\hline Peru & 1.7 & -0.9 & -0.6 & 1.4 & -0.4 & 7.5 \\
\hline Sweden & 1.4 & -0.2 & -0.3 & 1.4 & 0.5 & 17.3 \\
\hline Thailand & 1.2 & -1.1 & -1.3 & 0.5 & 0.4 & 50.0 \\
\hline United Kingdom & 0.4 & 0.1 & 0.1 & 0.4 & 0.2 & 14.1 \\
\hline \multicolumn{7}{|c|}{ Aggregate indicators } \\
\hline All countries & 1.3 & -0.4 & -0.5 & 1.0 & 0.3 & 15.1 \\
\hline $\begin{array}{l}\text { Prior disinflation } \\
\text { completed }\end{array}$ & 1.4 & -0.3 & -0.6 & 1.1 & 0.5 & 10.0 \\
\hline $\begin{array}{l}\text { Stable inflation } \\
\text { target from outset }\end{array}$ & 1.1 & -0.5 & -0.5 & 0.8 & 0.2 & 20.8 \\
\hline $\begin{array}{l}\text { Industrial } \\
\text { countries 3/ }\end{array}$ & 1.1 & -0.3 & -0.4 & 0.9 & 0.4 & 13.9 \\
\hline $\begin{array}{l}\text { Emerging market } \\
\text { countries 4/ }\end{array}$ & 1.6 & -0.6 & -0.7 & 1.0 & 0.3 & 17.3 \\
\hline
\end{tabular}

1/ Equally-weighted averages of corresponding statistics for individual countries in relevant groups. Individual country statistics are based on monthly (quarterly for Australia and New Zealand) differences between 12-month inflation rates and centers of target ranges.

2/ Persistence defined as the average number of months between changes in the sign on deviations of inflation from center of target range.

3/ Includes Australia, Canada, Finland, Iceland, Israel, Korea, New Zealand. Norway, Spain, Sweden, and the United Kingdom.

4/ Includes Chile, Czech Republic, Mexico, Peru, Poland, and Thailand. 
Table 16. Stable Inflation Target Stage: Deviations of Target Inflation from Target Range

\begin{tabular}{|c|c|c|c|c|c|c|c|c|c|}
\hline \multirow[t]{2}{*}{ Country } & \multicolumn{3}{|c|}{$\begin{array}{l}\text { Frequency of Deviations } \\
\text { (in percent) }\end{array}$} & \multicolumn{3}{|c|}{$\begin{array}{l}\text { Magnitude of Deviations } \\
\text { (in percent) }\end{array}$} & \multicolumn{3}{|c|}{$\begin{array}{l}\text { Duration of Deviations } \\
\text { (in months) }\end{array}$} \\
\hline & Total & Below & Above & Average & Below & Above & Average & Below & Above \\
\hline \multicolumn{10}{|c|}{ Disinflation completed } \\
\hline Canada & 21.1 & 11.4 & 9.6 & 0.5 & -0.3 & 0.8 & 2.4 & 1.9 & 3.7 \\
\hline Chile & 26.2 & 21.4 & 4.8 & 1.3 & -1.5 & 0.6 & 3.7 & 9.0 & 1.0 \\
\hline Czech Rep. & 76.2 & 76.2 & 0 & 2.0 & -2.0 & .. & 11.5 & 11.5 &.. \\
\hline Iceland & 0 & 0 & 0 & .. & .. & .. & .. & .. & .. \\
\hline Israel & 94.4 & 72.2 & 22.2 & 2.4 & -2.6 & 1.7 & 8.5 & 13.0 & 4.0 \\
\hline Mexico & 72.2 & 0 & 72.2 & 0.7 & .. & 0.7 & 6.5 & .. & 6.5 \\
\hline $\begin{array}{l}\text { New } \\
\text { Zealand }\end{array}$ & 19.6 & 2.2 & 17.4 & 0.4 & -0.5 & 0.3 & 6.8 & 3.0 & 8.0 \\
\hline Poland & 16.7 & 0 & 16.7 & 0.9 & .. & 0.9 & 1.0 & .. & 1.0 \\
\hline Spain & 0 & 0 & 0 & .. & .. & .. & .. & .. &.. \\
\hline \multicolumn{10}{|c|}{ Stable inflation target from outset } \\
\hline Australia & 44.4 & 28.9 & 15.6 & 0.4 & -0.5 & 0.2 & 8.6 & 13.0 & 5.3 \\
\hline Finland & 52.1 & 52.1 & 0 & 0.8 & -0.8 & & 9.3 & 9.3 & \\
\hline Korea & 4.8 & 0 & 4.8 & 0.1 & & 0.1 & 2.0 & & 2.0 \\
\hline Norway & 35.0 & 35.0 & 0 & 1.0 & -1.0 & & 14.0 & 14.0 & \\
\hline Peru & 40.0 & 36.7 & 3.3 & 1.3 & -1.4 & 0.8 & 4.0 & 5.5 & 1.0 \\
\hline Sweden & 42.8 & 29.7 & 13.0 & 0.9 & -0.7 & 1.2 & 7.4 & 10.3 & 4.5 \\
\hline Thailand & 2.0 & 2.0 & 0 & 0.1 & -0.1 & & 1.0 & 1.0 & \\
\hline $\begin{array}{l}\text { United } \\
\text { Kingdom }\end{array}$ & 0 & 0 & 0 & & & & & & \\
\hline \multicolumn{10}{|c|}{ Aggregate indicators 1/ } \\
\hline $\begin{array}{l}\text { All } \\
\text { countries }\end{array}$ & 32.2 & 21.7 & 10.6 & 0.9 & -1.0 & 0.7 & 6.2 & 8.3 & 3.7 \\
\hline $\begin{array}{l}\text { Previous } \\
\text { disinflation } \\
\text { completed }\end{array}$ & 36.3 & 20.4 & 15.9 & 1.1 & -1.4 & 0.8 & 5.8 & 7.7 & 4.0 \\
\hline $\begin{array}{l}\text { Stable } \\
\text { inflation } \\
\text { target from } \\
\text { outset }\end{array}$ & 27.6 & 23.0 & 4.6 & 0.7 & -0.8 & 0.6 & 6.6 & 8.8 & 3.2 \\
\hline $\begin{array}{l}\text { Industrial } \\
\text { countries }\end{array}$ & 28.6 & 21.0 & 7.5 & 0.9 & -0.9 & 0.7 & 7.4 & 9.2 & 4.6 \\
\hline $\begin{array}{l}\text { Emerging } \\
\text { market } \\
\text { countries }\end{array}$ & 39.0 & 22.8 & 16.2 & 1.0 & -1.3 & 0.7 & 4.6 & 6.8 & 2.4 \\
\hline
\end{tabular}




\section{Case Studies of Large Misses of Inflation Target Ranges}

\section{Brazil}

\section{Background}

Inflation targeting was adopted in June 1999 by presidential decree after Brazil was forced to abandon its crawling exchange rate peg in the wake of the Russian crisis in August 1998. The new framework and a tightening of monetary policy in the context of an IMF-supported financial package helped to lower inflation to the single digits. The inflation targets are set by the National Monetary Council based on a proposal by the Minister of Finance. The combination of headline inflation with relatively wide corridors in the absence of escape clauses accounts for the vulnerability of the Brazilian economy to economic shocks. If targets are breached, the President of the Brazilian Central Bank (BCB) should issue an open letter to the Minister of Finance explaining the causes of the breaches, measures to be adopted, and the period of time that will be needed for the measures to have an effect. Monetary policy is complicated by the high debt burden of Brazil, as well as the indexation of a large share of the debt (Table 17).

Table 17. Brazil: Key Macroeconomic Indicators, 2001-2003 (In percent)

\begin{tabular}{lllr}
\hline & 2001 & 2002 & 2003 \\
\hline General government deficit to GDP & -3.6 & -4.6 & -5.2 \\
General government gross debt to GDP & 77.2 & 93.4 & 85.9 \\
General government net debt to GDP & 55.1 & 65.5 & 60.3 \\
Current account balance to GDP & -4.6 & -1.7 & 0.8 \\
External debt to GDP & 41.2 & 45.8 & 43.7 \\
\hline
\end{tabular}

Source: IMF, World Economic Outlook.

\section{Overshooting of 2001-03}

During the first nine months of 2002 overshooting of the range averaged 1.7 percent but then rose quickly to 6.5 percent in December. The overshooting was attributed by the BCB mainly to the sharp exchange rate depreciation, the evolution of administered and monitored prices, and the deterioration of inflation expectations. The main shocks that triggered the overshooting were a cutoff of capital inflows as with emerging market countries generally, political risk during the run-up to the victory of President Lula da Silva in October 2002, and increases in managed prices.

The BCB increased the Selic interest rate from 18 to 25 percent during the last three months of 2003. Moreover, liquidity was withdrawn by an increase in compulsory reserves on demand deposits in March from 45 to 60 percent. 
The overshooting rose to 10.7 percent in May 2003 - the highest for an inflation targeting country - and declined to 7 percent by year-end. The decline of inflation reflected reduced investment early in the new administration, lower domestic demand ensuing from a drop in the real exchange rate, and a tightening of fiscal and monetary policies. The ex ante real Selic interest rate peaked at 14 percent during March to June and ended the year at 8 percent and in August compulsory reserves on demand deposits were lowered from 60 percent to 45 percent. The primary surplus of 5 percent of GDP exceeded the IMF target. Real GDP growth was slightly positive.

As of January 2004, inflation appeared poised to drop back within the inflation targeting range and the credibility of the inflation targeting framework appeared to remain good. Twelve-month-ahead inflation expectations had dropped to 5.6 percent by December and monetary policy had loosened substantially, suggesting that the cycle of overshooting had ended. Other indicators were positive, including a sharp drop in external debt spreads, a reduction in the debt to GDP ratio, and an expected recovery of growth.

\section{Changes in the inflation targeting framework}

The episode of overshooting did not generate significant changes in the institutional framework of inflation targeting but did appear to trigger alterations to the operational aspects of the inflation targeting framework. The inflation targeting range was adjusted slightly several times and was set for 2004 at 1.5 to 6.5 percent. Beginning in June 2002 the BCB began to base its policy stance on an "adjusted" inflation target which consists of the sum of three components: (i) the inflation target pre-established by the central monetary committee; (ii) the inertial impact of the previous year's inflation; and (iii) the primary effect of shocks to administered and monitored prices. This approach accommodates the direct impact of shocks on the price level, but addresses their secondary effects and allows convergence to the pre-announced inflation target. The decision to pursue an inflation trajectory based upon these adjusted targets considers that monetary policy will be able to lead inflation to converge to the target tolerance interval in two years.

\section{Broad lessons}

The recent drop in inflation and inflation expectations to below the target ceiling suggests that Brazil's inflation targeting framework has demonstrated resilience to large economic and political shocks. Despite the large magnitude of the overshooting there were no institutional changes to the inflation targeting framework.

- $\quad$ The overshooting reflected high exchange rate pass-through and political stability, both of which are beyond the control of monetary policy.

- $\quad$ Success reflected good cooperation between the Ministry of Finance and BCB, strong political support for inflation targeting, and fiscal tightening. 
- $\quad$ Unusually, the BCB moved from a standard headline inflation measure to an adjusted inflation as target in the context of high exchange rate pass-through and embedded wage and price inertia.

- The reserve requirement was used as an extra policy instrument during the overshooting.

\section{Czech Republic ${ }^{19}$}

\section{Background}

The Czech National Bank (CNB) adopted an inflation targeting framework in December 1997. A floating exchange rate regime had been adopted in May 1997 prompted by speculative attacks and prospective membership of the European Union. The CNB began by targeting "net inflation," which excludes regulated prices and effects of changes in taxes. The net inflation index covers 82 percent of the broad CPI basket and consists of about onethird food items. The CNB established an escape clause, or "exceptions" under which monetary policy is authorized not to respond immediately to certain shocks. ${ }^{20}$ Monetary policy is complicated by weaknesses in the banking sector and by wage rigidities, but the fiscal and external positions are relatively strong (Table 18). In particular, the principle of a balanced central budget was followed throughout the transitional period, and public sector borrowing remained moderate. Further, a consensus between the Government and the CNB on the price and monetary stability target was incorporated into the document of the Czech Government, "Economic Strategy of the Accession to the European Union," which is the fundamental document for economic policy orientation in the run-up to EU accession (Czech National Bank, 2000, Chapter 7). Thus, the independence of monetary policy was not undermined by a loss of fiscal discipline. More generally, the Czech authorities have emphasized continuity in policy objectives and a medium-term policy focus.

\section{Undershooting of 1998-99}

The undershooting of the inflation target range in 1998-99 was the largest of any inflation targeting country by a wide margin. From October 1998 to December 1999 the undershooting averaged some 3.8 percent, notwithstanding the reduction in the target from 5.5-6.5 percent in 1998 to $4-5$ percent in 1999 . The undershooting mainly reflected lower than expected domestic food prices and the drop in world fuel prices. The drop in food prices was driven by favorable domestic supply considerations and especially by downward pressure on retail prices induced by the entry of foreign competition.

\footnotetext{
${ }^{19}$ The Czech experience with inflation targeting is described in Czech National Bank (2000).

${ }^{20}$ These shocks include global raw material price shocks; exchange rate movements unconnected with domestic economic fundamentals and monetary policy; agricultural production shocks; and natural disasters.
} 
The CNB eased monetary policy by lowering the policy 14-day repo rate from 15 percent in July 1998 to 5.75 percent in October 1999. Interest rates were lowered in line with declining inflation expectations and the worldwide fall in policy interest rates. Monetary conditions were eased much more slowly owing to exchange rate depreciation and the gradual decline in inflation expectations. The CNB remained concerned about the potential for exchange rate instability caused by a rapid fall in interest rates, as well as uncertainties about monetary policy transmission arising from weaknesses in the banking sector and the difficulty of forecasting inflation. The CNB also consulted with trade union representatives with a view to acquainting the unions with inflation projections.

Table 18. Czech Republic: Key Macroeconomic Indicators, 1999-2001

(In percent)

\begin{tabular}{lrrr}
\hline & 1999 & 2000 & 2001 \\
\hline General government deficit to GDP & -3.1 & -3.2 & -2.8 \\
General government gross debt to GDP & 13.4 & 15.5 & 17.5 \\
General government net debt to GDP & 13.3 & 14.9 & 16.1 \\
Current account balance to GDP & -2.5 & -4.9 & -5.4 \\
External debt to GDP & 38.4 & 38.8 & 36.8 \\
\hline
\end{tabular}

Source: IMF, World Economic Outlook.

Inflation rose during 2000 to reach the bottom of the 3.5-5.5 percent band late in the year. The increase in inflation reflected the easing of policy, significant exchange rate depreciation, and the recovery and food and world fuel prices. In April 2000, the CNB announced a 2-4 percent target for end-2001, which was subsequently endorsed by the government.

\section{Changes in the inflation targeting framework}

The changes in the framework announced in April 2001 were partly attributed to the undershooting of the target. First, the CNB shifted to targeting headline CPI inflation. Second, the target was formulated as continuous throughout the year, rather than for year-end. Third, as a transition the annual net inflation target for the end of 2001 was set at 2-4 percentage points and the overall CPI at 5 percent. Fourth, future targets would be set in April in tandem with the macroeconomic framework for the state budget for the following year.

\section{Broad lessons}

The Czech authorities took advantage of undershooting during disinflation.

- The switch from "net inflation" to the broad CPI suggests that the latter offers important advantages, especially when the former includes food prices. 
- $\quad$ The articulation of medium-term monetary and fiscal policy objectives facilitated consistent policies and helped the Czech Republic limit the impact of the large undershootings.

- Weaknesses in the banking sector made policy transmission more difficult thereby complicating monetary policy.

- Wage stickiness via the influence of unions probably contributed to the persistency of inflation.

- $\quad$ The initial role for escape clauses seems not to have been enacted.

\section{Iceland}

\section{Background}

Inflation targeting was adopted by Iceland in a joint declaration by the Central Bank of Iceland (CBI) and the Government of Iceland on March 27, 2001. The CBI Law was changed to make price stability the main monetary policy objective. The CBI aims at an average rate of inflation, measured as the annual 12-month increase in the headline CPI, which includes a large share of imported goods ( 30 percent) but excludes housing interest rate costs. The inflation target range was $3 \frac{1}{2} \pm 1 \frac{1}{2}$ percent for 2001 narrowing to $2 \frac{1}{2}$ percent if possible by the end of 2003. If inflation deviates by more than $\pm 1 \frac{1}{2}$ percentage points from the target, the Central Bank is obliged to submit a public report to the Government explaining the reasons for the deviations from the target, how the Bank intends to react and how long it will take to reach the inflation target again in the Bank's assessment. Iceland has a fairly strong fiscal position, but it is small, open and has a large external debt (Table 19).

Table 19. Iceland: Key Macroeconomic Indicators, 2000-2002 (In percent)

\begin{tabular}{lrrr}
\hline & 2000 & 2001 & 2002 \\
\hline General government deficit to GDP & 2.5 & 0.2 & -1.1 \\
General government gross debt to GDP & 41.9 & 47.5 & 44.1 \\
General government net debt to GDP & 24.0 & 26.9 & 25.1 \\
Current account balance to GDP & -10.1 & -4.1 & -0.3 \\
\hline
\end{tabular}

Source: IMF, World Economic Outlook.

\section{Overshooting of 2001-02}

The overshooting of the inflation target averaged 3.2 percent during the period of September 2001 to April 2002 and peaked at 4.4 percent in February 2001. The surge in inflation was largely due to the 30 percent depreciation of the nominal effective exchange rate during the period of January to November 2001, attributable to a large current account deficit and net outflow of foreign direct investment and portfolio capital. In addition, real 
wage rose and there was a positive fiscal stimulus during $2001 .^{21}$ A sizeable positive output gap on the heels of several year of strong growth helped sustain the inflation overshooting.

Interestingly, evidence for slackness in the economy led the CBI to lowered interest rates during the overshooting. It lowered the policy interest rate twice, by 0.5 percentage points at the end of March and by 0.8 percentage points at the beginning of November to bring the interest rate to an average of 10.1 percent for November-December. The Central Bank also engaged in partially sterilized sales of foreign exchange at the end of September and beginning of October to support the currency. In retrospect the CBI expressed the view that the exchange rate trend for most of the year was much less favorable than it had assumed and inflation correspondingly higher than had been forecast. It was not until towards the end of the year that the króna began to strengthen and the prospects for stability began to improve. As required under the new inflation targeting framework the CBI prepared a report on the overshooting of the inflation target and the policy response which was sent to the government in June. ${ }^{22}$

Inflation declined to below the 4.5 inflation target range ceiling in March 2002 in the context of the rise of the króna and subdued domestic demand. The CBI's policy rate was reduced by a total of 4.3 percentage points during 2002. In August inflation had already moved within the tolerance limit for 2002 and in November fell below the long run target of $2 \frac{1}{2}$ percent. Measured in terms of the inflation premium on government bonds with a lifetime of around 4 years, the real policy rate was in the range $6-71 / 2$ percent for most of 2002 , but just over 3 percent at the end of the year.

\section{Changes in the inflation targeting framework}

There were no changes to the inflation targeting framework.

\section{Broad lessons}

Overshooting did not lead to a loss in credibility or to any changes in the framework.

- $\quad$ Iceland is highly vulnerable to exchange rate shocks.

- A good fiscal position helped maintain the credible inflation targeting framework.

\footnotetext{
${ }^{21}$ However, in December 2001 labor unions agreed to postpone the scheduled review of labor contracts to May 2002 and increase the threshold level of wages that would trigger a revision of wages from 3 percent to 6.3 percent.

${ }^{22}$ In the view of the CBI, a subsequent report of this kind would not be required unless inflation goes outside the tolerance limits again after having been within them.
} 


\section{Israel}

\section{Background}

The adoption of a full-fledged inflation targeting framework for Israel can be marked with the widening of the exchange rate band to 40 percent in June 1997. The long transition to inflation targeting began with the move to a crawling exchange rate band in December 1991 that necessitated inflation targets to define the upward slope of the crawl. The CPI is the inflation target index owing to of financial and wage contracts linked to the CPI. The first three annual inflation targets were announced jointly by the Ministry of Finance (MoF) and the Bank of Israel (BoI), thereafter, the targets were announced by the MoF in consultation with the BoI. In 1996 when the government announced a long-term objective of bringing inflation down to the average of member countries of the Organization for Economic Cooperation and Development by 2001. Since August 1998, the BoI Governor has been required to publicly explain deviations of expected inflation from the target of more than one percentage point. Monetary policy is complicated by quite high levels and indexation of government debt (Table 20).

Table 20. Israel: Key Macroeconomic Indicators, 1997-2003 (In percent)

\begin{tabular}{lrrrrrrr}
\hline & 1997 & 1998 & 1999 & 2000 & 2001 & 2002 & 2003 \\
\hline General government deficit to GDP & -4.5 & -3.7 & -4.2 & -2.1 & -4.1 & -4.5 & -6.4 \\
General government gross debt to GDP & 103.9 & 106.7 & 101.4 & 91.4 & 96.4 & 104.9 & 107.4 \\
General government net debt to GDP & 86.8 & 85.8 & 87.8 & 80.1 & 85.1 & 93.6 & 96.1 \\
Current account balance to GDP & -3.9 & -1.3 & -1.5 & -1.2 & -1.9 & -1.6 & 0.1 \\
\hline
\end{tabular}

Source: IMF, World Economic Outlook.

\section{Undershooting of 1998}

The undershooting of the inflation target range by an average of 2.8 percent during MarchSeptember 1998 reflected tight policies. The 7-10 percent inflation target had been set in August 1997. The slowing of the rate of inflation extended to all the components of the CPI in line with lower inflation expectations and the downward trend of inflation. The trend was sustained by relatively tight fiscal and monetary policies aimed at containing the prolonged economic expansion arising from immigration in the early 1990s.

The undershooting was viewed favorably by the BoI as it brought inflation toward the long term goal faster than expected. Further, the BoI was able to lower its policy interest rate by some 450 basis points during January-September in line with a pronounced fall in inflation expectations. In August 1998, the Minister of Finance, in concert with the Prime Minister and the Governor of the Bank of Israel, set an inflation target of 4 percent for 1999, thereby locking in the lower inflation. 
The turmoil in international financial markets beginning in September led to a sharp currency depreciation and a turnaround in inflation. Inflation rose from 3.2 percent in August to 8.6 percent at year end, triggering another cycle of monetary policy tightening.

\section{Undershooting of 2000-01}

Inflation fell short of the target in 2000 mainly because of unexpected currency appreciation. The 3-4 percent target for 2000 and 2001 was set in December 1999. During August 2000-February 2001 the floor of the target was undershot by an average of 2.7 percent. The unexpected decline of inflation reflected strong productivity growth that sustained a negative output gap. Further, in contrast to the widespread easing of inflation in 1998, during this episode several components of the CPI basket (clothing and footwear, furniture, and housing) fell markedly, while others rose, and there was significant disparity in the contribution of the different components to the overall CPI. The differential behavior of the CPI components reflected tax policies and a sharp depreciation of the currency.

The BoI continued to ease monetary policy although by less than the decline in real interest rates owing to financial and other vulnerabilities. The policy interest rate was reduced by some 465 basis points from February 1999 to July 2000, and lowered by another 138 basis points from July 2000 to January 2001. However, the corresponding declines in real interest rates were much smaller. The slow loosening of policy during the undershooting was meant to avoid interest rate and exchange rate volatility and Israel's vulnerability to shocks, including the NASDAQ decline, uncertainty regarding tax reform, unrest in the territories, and political instability.

Inflation rose gradually during 2001 and touched the bottom of the inflation target range only in September in the context of the continuation of the intifada, the fall in prices of assets in international financial markets, and the slowdown in western economies. The BoI continued to ease policy through January 2002.

In August 2000, as part of the process of adopting the European standard for macroeconomic policy management, the government, for the first time, defined long-run price stability as 1-3 percent and set this range as the monetary policy target for 2003 . In addition, the target for 2001 was lowered from the 3-4 percent announced one year earlier to $2 \frac{1}{2}-3 \frac{1}{2}$ percent.

\section{The overshooting of 2002-03}

Inflation overshot the inflation target during late 2002 and early 2003 owing to policy slippages and external and domestic shocks. The overshooting averaged 3.1 percent during April 2002 to February 2003, peaking at 3.9 percent in October, making it the third largest overshooting of any inflation targeting country. In December 2001, the BoI had lowered interest rates by 200 basis points on the understanding of a fiscal tightening, but the ensuing fiscal slippages combined with the large loosening hurt policy credibility and contributed to an increase in inflation expectations. Further, inflation was worsened by the bursting of the high technology bubble which led to a sharp cutback in capital inflows and a 20 percent 
depreciation during the first half of 2002. Developments were worsened by the impact of the intifada on tourism, construction and the supply of Palestinian workers, as well as by the global slowdown. The credibility of the commitment to price stability may also have been impacted by the government's intention to limit the independence of the BoI through a change in the BoI law. Inflation expectations rose during the first half of the year to above the inflation target range.

The BoI responded by raising its policy interest rate by 567 basis points during January to July 2002. The tightening of monetary policy, combined with fiscal measures and tax reforms, led to a quick turnaround in inflation expectations, which dropped to below the ceiling of the inflation target range at end-2002.

\section{Broad lessons}

- $\quad$ There is a strong case for accepting under-shootings of short-run inflation target range with a view to accelerating attainment of the long run inflation objective. These under-shootings led to downward adjustments of the target range.

- Importance of exchange rate shocks and pass-through.

- $\quad$ Scope to ease in context of undershooting may be reduced if there is potential exchange rate or financial instability.

- Importance of institutional price rigidities left over from higher inflation period, including automatic wage increases in the general government sector, a tax system adapted to conditions of inflation, government contracts indexed to the CPI, and the pricing of large transactions in foreign currency.

- $\quad$ Better coordination between the MoF and the BoI could have lessened the impact of strong shocks to inflation.

- Important to have a central law in place that supports price stability and gives the central bank sufficient independence to operate inflation targeting.

\section{Poland}

\section{Background}

The National Bank of Poland (NBP) announced that it would adopt inflation targeting in September 1998 and the advent of full-fledged inflation targeting can be marked by the widening of the exchange rate band to \pm 15 percent in March 1999. Inflation targeting was viewed to be the most effective means to reduce inflation and pave the way for European Union (EU) accession. The new central bank act that came into effect in January 1998 defined the NBP's primary objective as price stability and established NBP instrument independence. The new constitution of the Republic of Poland prohibits central bank 
financing of public deficits. The NBP Act also created a Monetary Policy Council. In September 1998 the NBP published its medium-term strategy of lowering inflation to 4 percent by 2003 and announced a disinflation path.

The supporting environment for monetary policy has been mixed (Table 21). Poland does not have especially high government debt but the fiscal position has deteriorated in recent years. The external debt burden is relatively low and the current account has narrowed recently. The banking system is highly concentrated and some key banks are subject to balance sheet stresses thereby complicating monetary transmission. The labor market is relatively rigid.

Table 21. Poland: Key Macroeconomic Indicators, 1999-2003 (In percent)

\begin{tabular}{lrrrrr}
\hline & 1999 & 2000 & 2001 & 2002 & 2003 \\
\hline General government deficit to GDP & -3.0 & -3.0 & -5.3 & -6.3 & -5.8 \\
General government gross debt to GDP & 40.5 & 36.9 & 40.2 & 45.1 & 49.8 \\
General government net debt to GDP & 42.7 & 39.4 & 40.3 & 46.3 & 49.8 \\
Current account balance to GDP & -7.6 & -6.0 & -2.9 & -2.6 & -1.9 \\
External debt to GDP & 39.7 & 41.7 & 38.7 & 44.3 & 49.6 \\
\hline
\end{tabular}

Source: IMF, World Economic Outlook.

\section{Overshooting episode of 2000}

During 2000 actual inflation exceeded the 5.4-6.8 target range owing to a combination of energy and food developments, easier monetary policy and structural rigidities. The acceleration of inflation that began in August 1999 was triggered by higher fuel prices brought on by higher world import prices and customs duty and taxes. Food prices surged due to weather and domestic supply factors. The impact on overall inflation of increased fuel and food prices was exacerbated by the lagged effect of easier monetary policy in 1999 (which was predicated on a fiscal tightening that according to the NBP was not realized), nominal rigidities in the form of widespread wage contracts and limited competition in key sectors. Annual CPI inflation peaked at 11.6 percent in July, some 4.8 percent above the ceiling.

The NBP tightened monetary policy beginning in late 1999 in response to the absence of the expected tightening in fiscal policy which led to strong domestic demand, and depreciation arising from the slow pace of export readjustment. The policy interest rate, the minimum 28-day reverse repo rate, was raised from 13 percent to 14 percent in September and in November to 16.5 percent. The policy interest rate was further increased in February 2000 to 19 percent in response to the swift price growth that was set to continue. In August rates were raised to 19.5 percent counter the secondary inflationary effects of the rapid growth in food and fuel prices that had occurred due to supply disruptions on the markets concerned in the context that the strictness of fiscal policy was less than previously envisaged. 
The tightening of monetary policy and other factors restrained domestic demand growth and led to declining inflation beginning in September 2000. In the latter half of 2000, the impact of high fuel prices on inflation started to wane, while food price growth also began to lose momentum as of August. Coupled with the tightening of monetary policy pursued since September 1999, these developments had the effect of curbing inflation considerably from July onwards, while the inflation target set for December was attained just two months later. In February 2001, inflation dropped to below 6.6 percent, just below the 2000 ceiling. In March 2001, the policy rate was reduced. Average twelve month ahead inflation expectations (by bank analysts) rose slightly to just above 7 percent in November 2000 and ended the year at 6.9 percent.

\section{Undershooting episode of 2002}

Inflation undershot the inflation target range by more than 2 percent during the period of May to December 2002 owing to weak domestic demand, lower than expected food prices, labor market slackness, and worse than forecast global economic conditions. The undershooting was largest in December at 3.2 percent when the CPI registered a 0.8 percent annual increase. Food prices were lower than expected due to lower excise duty rates, small increases in administratively regulated prices and robust supply. Wage growth was slowed by productivity increases and higher unemployment reflecting the rigidity of the labor market.

In 2002, the Monetary Policy Council reduced NBP base rates eight times. From February 2001 until the end of 2002 the rates were trimmed from 19 percent to 6.75 percent. The fall in nominal and real interest rates was accompanied by a substantial depreciation of the zloty. The reasons for the interest rate reductions were as follows: a reduction, and subsequent stabilization at a low level, of current inflation rate as well as all core inflation measures; a decrease, and subsequent stabilization at a low level, of the inflation expectations of both consumers and bank analysts; unfavorable and worsening prospects for global economic growth, including in particular those for the German economy; moderate salary growth within the national economy, and monetary processes encouraging the containment of inflationary pressures. From the very beginning of the year, inflation expectations of both consumers and bank analysts gradually fell back.

The most recent data indicate that inflation is trending upward back toward the bottom of the inflation target range. Inflation bottomed out in April 2003 at 0.3 percent and rose to 1.6 percent in November. The policy interest rate has been at 5.25 percent since June. 


\section{Changes in the inflation targeting framework}

The overshooting of inflation in 2000 did not lead to substantive changes in the inflation targeting framework. ${ }^{23}$ In the annual monetary policy guidelines released in September 2000 the NBP maintained its goal of bringing down inflation to under 4 percent by the end of 2003 and it shifted up the inflation target from 5.4-6.8 percent in 2000 to 6-8 percent in 2001 owing to uncertainty regarding supply factors.

The undershooting of 2002 led to adjustments of the inflation target range. In September 2001, the Monetary Policy Committee (MPC) announced an inflation target range of 4-6 percent for 2002. In June, the MPC announced the 2002 inflation target range from 4-6 percent to 3-4 percent owing to unexpected temporary supply shocks. A permanent inflation target range of 2.5-4.5 percent was established in the Monetary Policy Strategy beyond 2003 published in March 2003.

\section{Broad lessons}

The process of disinflation for Poland has been completed, although views differ regarding whether disinflation could have been attained at a lower cost to output.

- $\quad$ The inflation targeting regime has been marked by disagreement between the MoF and the NBP. Better and/or more formal institutional cooperation could have reduced uncertainties and smoothed long-term adjustment.

- $\quad$ The large share of the CPI basket accounted for by food and administered prices increased fluctuations in the CPI and made attainment of the inflation target more difficult.

- $\quad$ The width of the inflation target range (1.4 percent during 2000 and 2 percent thereafter) may have been too narrow for a country undergoing structural changes away from nominal rigidities and using the broad CPI as the inflation measure.

- $\quad$ Monetary policy is complicated by weak pass-through reflecting banking sector weaknesses and by labor market rigidities.

\footnotetext{
${ }^{23}$ During 2000 the authorities also floated the zloty in April and the NBP began to sell Treasury securities from its own portfolio in order to reduce the surplus operating liquidity within the banking system, but these measures were not related to the overshooting of the inflation target.
} 


\section{South Africa}

\section{Background}

The Minister of Finance announced the adoption of inflation targeting in his budget speech in February 2000. The first inflation target was announced by the government after consultations with the South African Reserve Bank (SARB) and the framework initially included an escape clause for major unforeseen events outside central bank control. The target was an annual average inflation rate of the CPI excluding mortgage costs (CPIX). A 3-6 percent target was announced for 2002 and 2003, and a 3-5 percent target for 2004 and 2005. No explicit target was set for the transition period between February 2000 and 2002. The target range reflects the uncertainties about the inflation process and the required discretion in monetary policy. The fiscal and external positions of South Africa are good and have improved since the adoption of inflation targeting (Table 22).

Table 22. South Africa: Key Macroeconomic Indicators, 2001-2003

(In percent)

\begin{tabular}{lrrr}
\hline & 2001 & 2002 & 2003 \\
\hline General government deficit to GDP & -1.2 & -1.2 & -2.1 \\
General government gross debt to GDP & 43.0 & 38.5 & 37.3 \\
Current account balance to GDP & 0.0 & 0.6 & -0.8 \\
External debt to GDP & 27.0 & 30.7 & 23.2 \\
\hline
\end{tabular}

Source: IMF, World Economic Outlook.

\section{Overshooting of 2002-03}

The inflation target was overshot by an average of 3.7 percent during the period of April 2002 to April 2003 in the wake of a sharp depreciation of the rand. The overshooting peaked at 5.3 percent in October-November 2002. The overshooting was brought on by the 35 percent depreciation of the rand during the last four months of 2001, an increase in world oil and grain prices, and uncertainties regarding the loosening of exchange controls. The SARB attributed the currency depreciation to regional political instability and an increase in international investor risk aversion with respect to emerging market countries. The SARB also stated that the depreciation gained momentum owing to possible speculation and leads and lags in purchases by importers and exporters.

The SARB reversed the decline in the policy repo rate beginning in November 2001 and brought the repo rate to 13.5 percent in September 2002. In real terms, the repo rate peaked at a little above 8 percent in May 2003. The government also moved to privatize the telecommunications company.

CPIX inflation fell from a peak of 11 percent in during the fourth quarter of 2002 to 4.2 percent in October 2004. The fall was a result of the rapid recovery of the rand and lower 
world grain prices. The appreciation appeared to have been driven by higher commodity prices, the weakening of the U.S. dollar, and improved domestic growth. By late 2003, expected inflation had also fallen to below the 6 percent inflation target ceiling.

Monetary policy was loosened ahead of the decline of inflation to below the 6 percent ceiling in September 2003. The repo rate was reduced to 7.5 percent - its lowest level since 1980. At the same time, inflation expectations surveys suggested that inflation would remain in the middle of the 3-6 percent range during 2004 and 2005.

\section{Changes in the inflation targeting framework}

There were no major changes to the framework in response to the overshooting. In October 2002, the Minister of Finance announced that the 3-5 percent target for 2004 would be adjusted upward slightly to 3-6 percent. Similarly, in February 2003 the Minister announced that the 3-5 percent target for 2005 would also be adjusted to 3-6 percent. Interestingly, the SARB chose not to trigger the escape clause allowed in the inflation targeting framework. The letter written by the Minister of Finance to the Governor of the SARB on the inflation targeting framework outlining the handling of unforeseen events outside central bank control. However, the SARB said it chose not to trigger the escape clause because there was scope for a tightening of monetary policy in the context of the exchange rate depreciation.

\section{Broad lessons}

Overshooting did not lead to a loss in credibility or lead to major changes in the framework.

- Importance of strong fiscal and external positions.

- Inclusion of administered prices in the CPI target index complicates monetary policy.

- $\quad$ Good cooperation between the MoF and SARB.

- $\quad$ Escape clause was not used.

- Importance of exchange rate pass-through. 
Brazil: 2001-2004

Figure 1.Target Inflation, Lower and Upper Band of Inflation Target

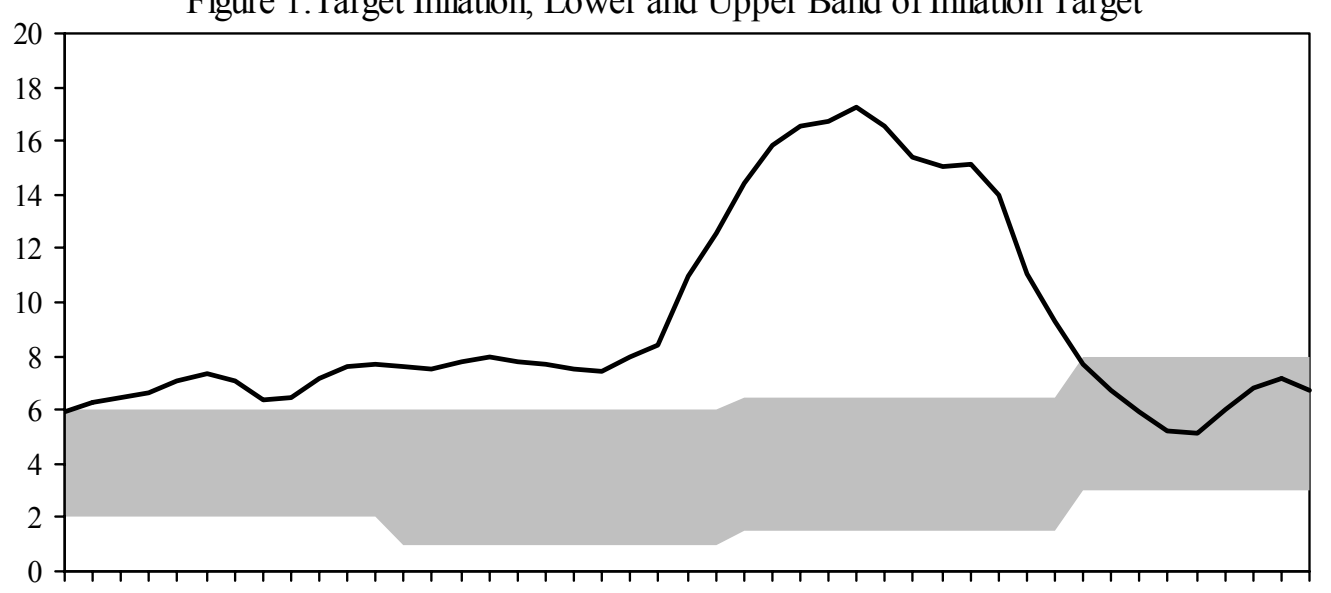

2001M1 2001M5 2001M9 2002M1 2002M5 2002M9 2003M1 2003M5 2003M9 2004M1 2004M5 2004M9

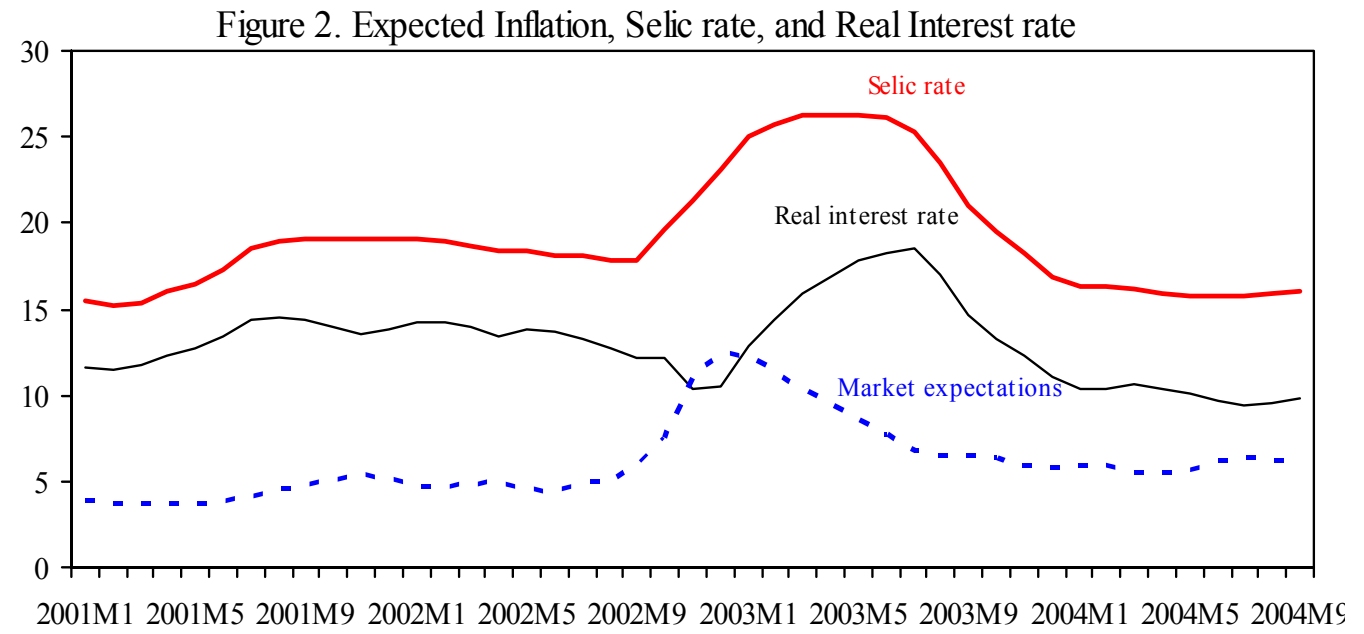

Figure 3. Exchange Rate, year-on-year percentage change

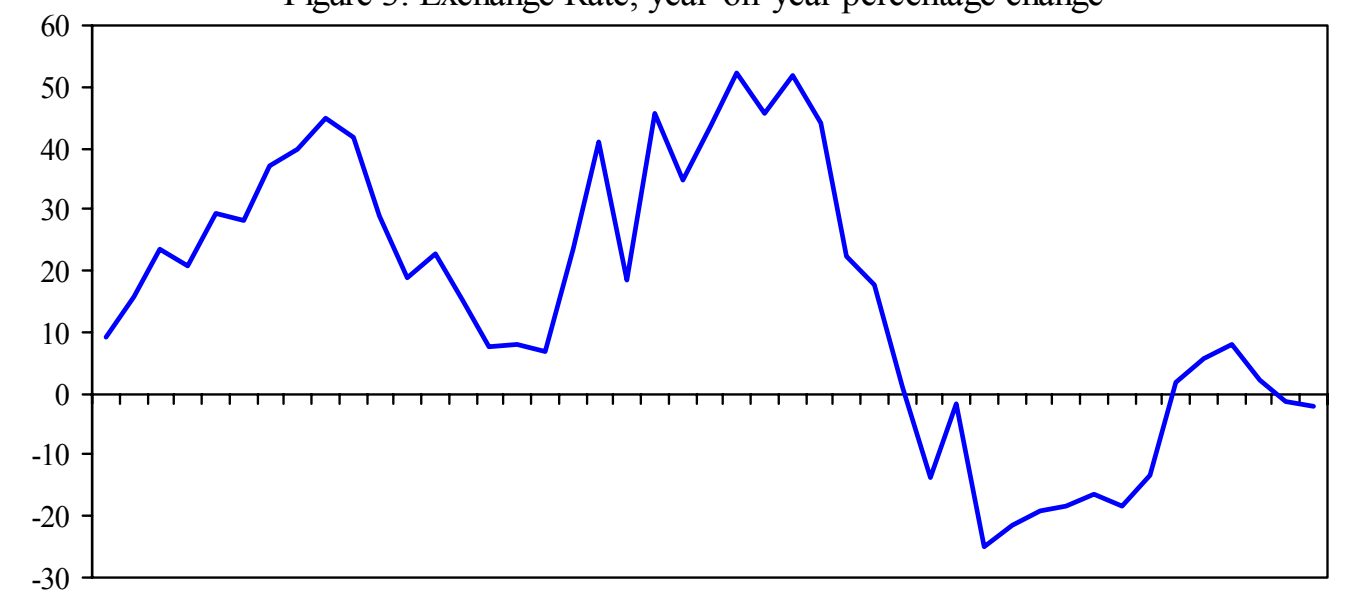

2001M1 2001M5 2001M9 2002M1 2002M5 2002M9 2003M1 2003M5 2003M9 2004M1 2004M5 2004M9

Source: Banco Central do Brasil. 
Czech Republic: 1999-2001

Figure 1. Inflation target, Lower and Upper Band of Inflation Target

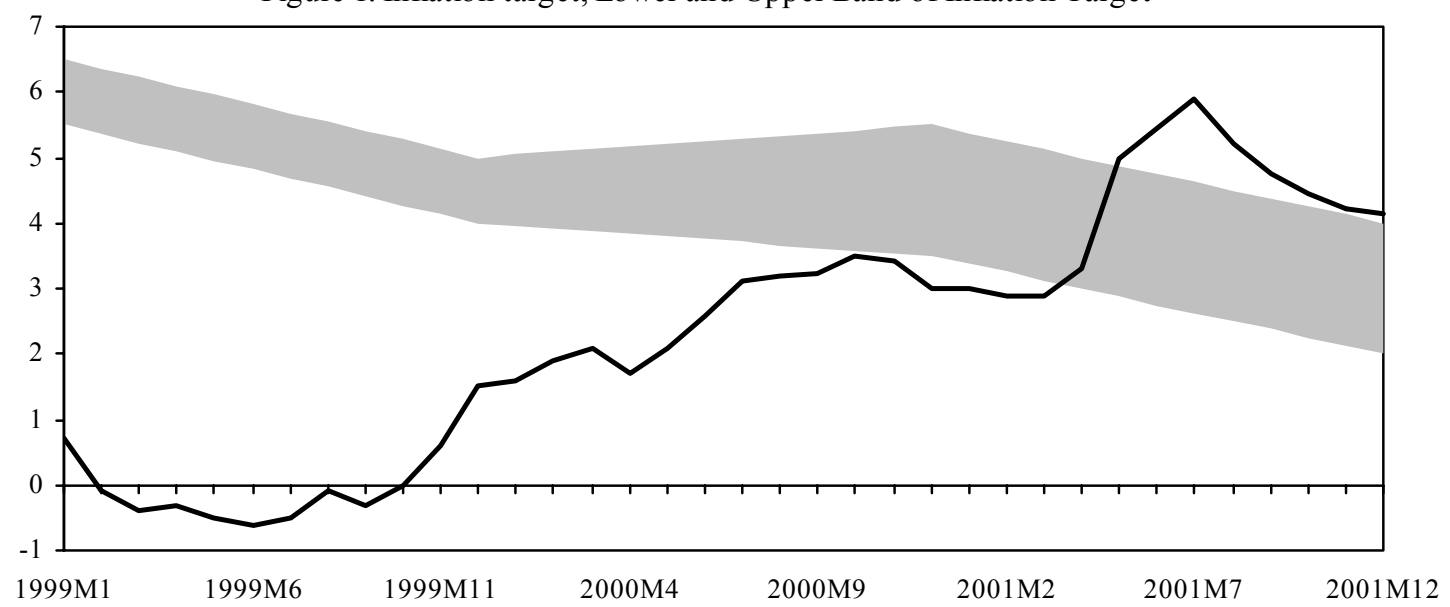

Figure 2. Expected Inflation and 14-day Pribor rate

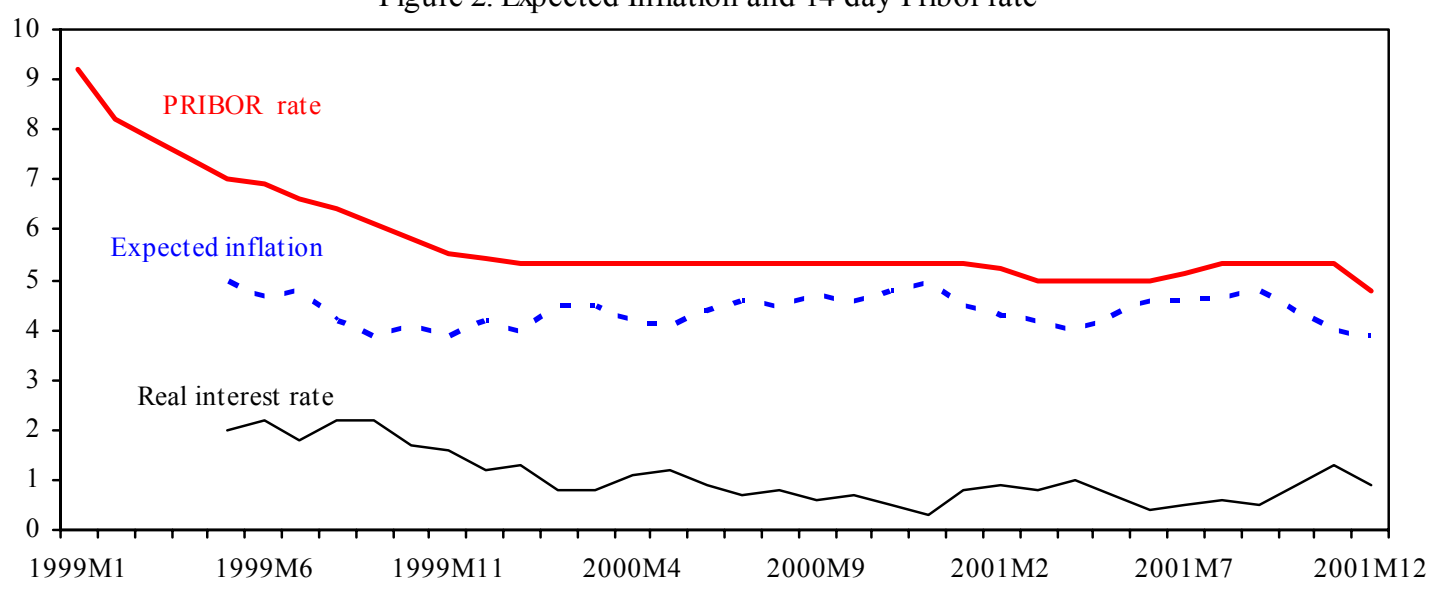

Figure 3. Exchange Rate, year-on-year percentage change

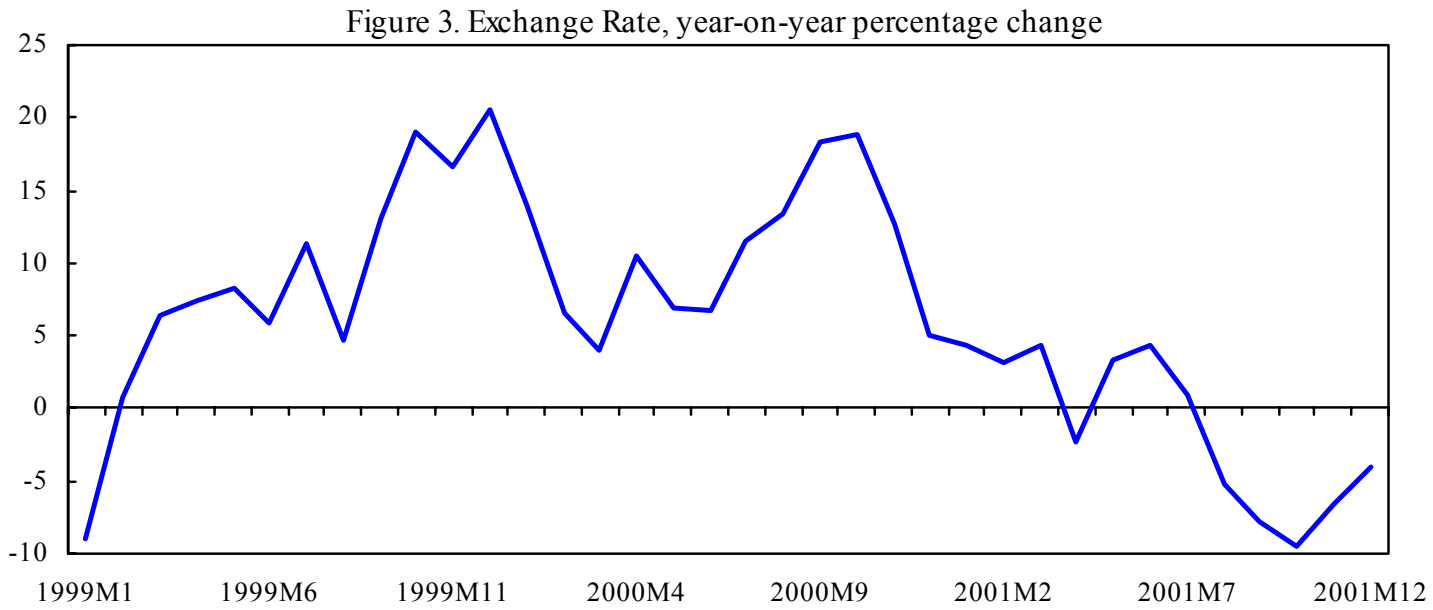

Source: Czech National Bank, IFS. 
Iceland: 2001-2003

Figure 1. Target Inflation, Lower and Upper Band of Inflation Target

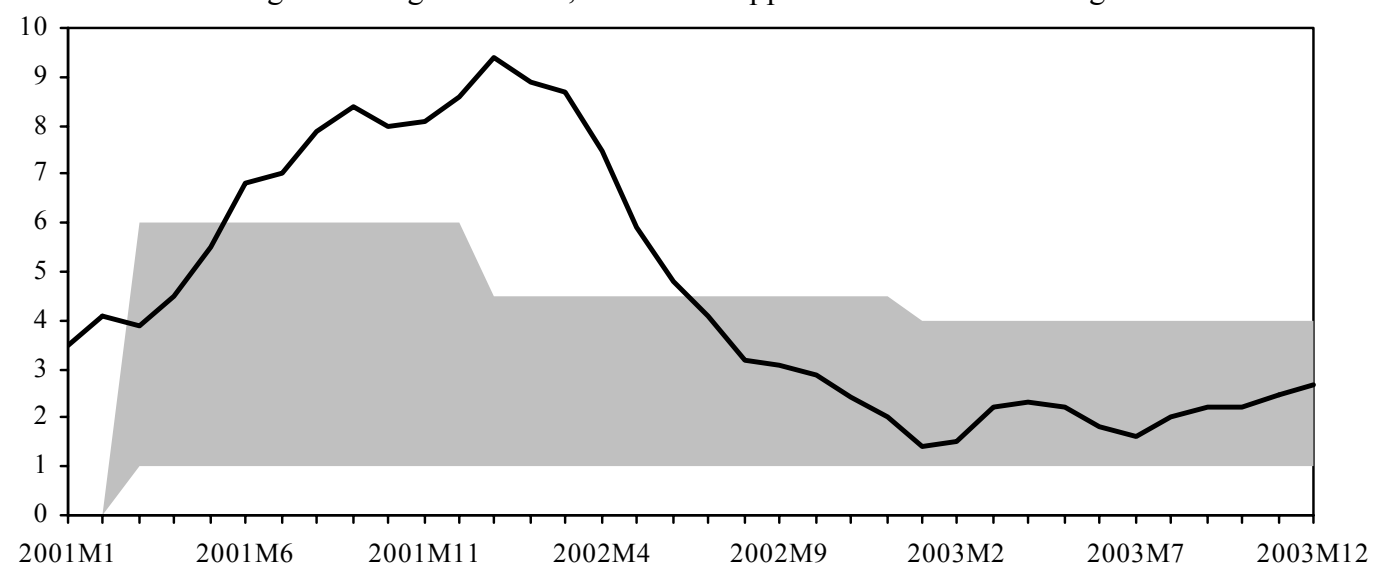

Figure 2. Expected Inflation, Central Bank Policy Rate, and Real Interest Rate

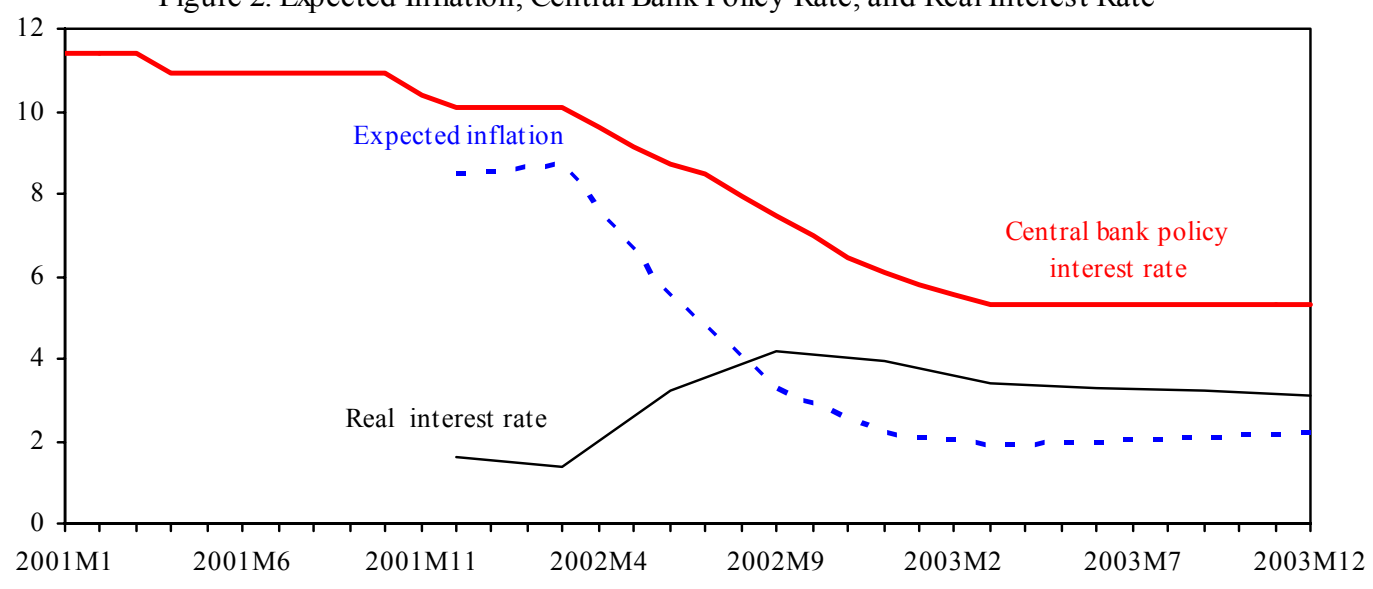

Figure 3. Exchange Rate, year-on-year percentage change

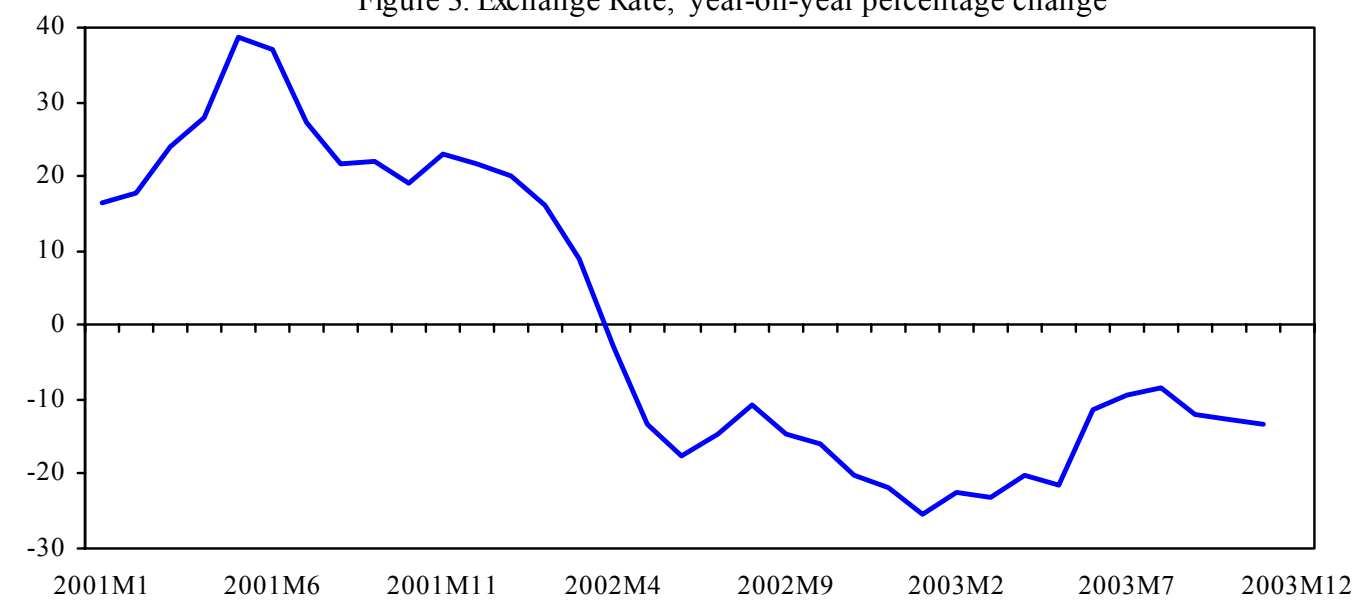

Source: Central Bank of Iceland, IFS. 
Israel: $1997-2004$

Figure 1. Target Inflation, Lower and Upper Band of Inflation Target

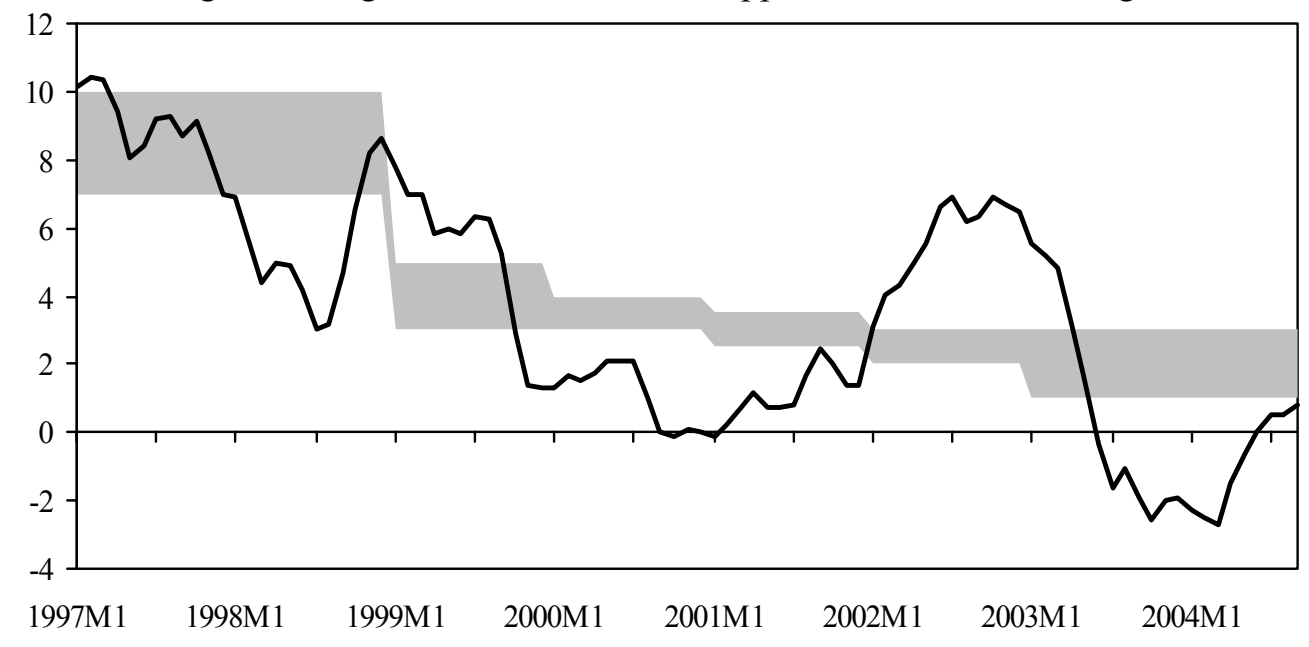

Figure 2. Expected Inflation, BOI Rate of Interest, and Real Interest Rate

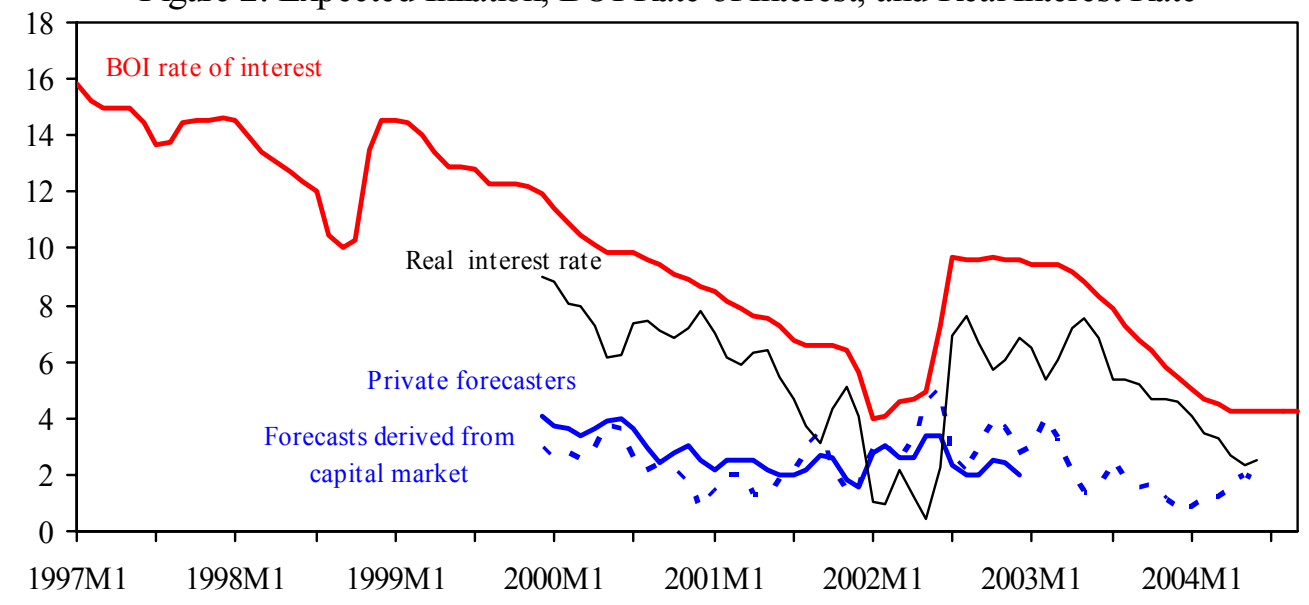

Figure 3. Exchange Rate, year-on-year percentage change



Source: Bank of Israel. 
Poland: 1999-2003

Figure 1. Target Inflation, Lower and Upper Band of Inflation Target

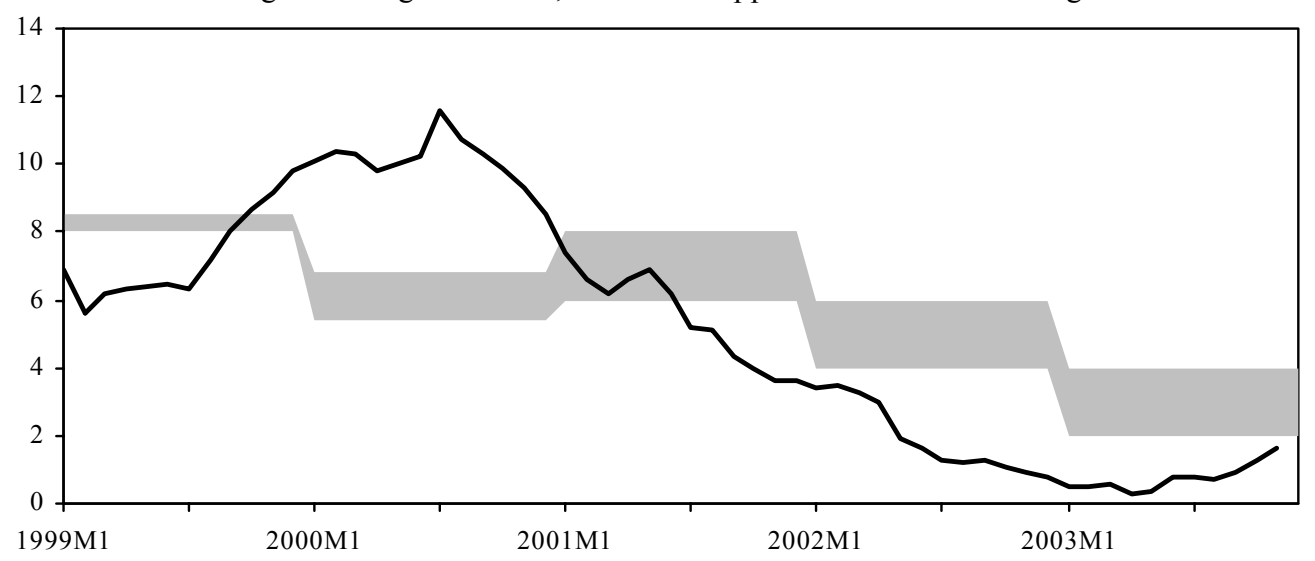

Figure 2. Consumers and Banks Expected Inflation, NBP Reference Rate,

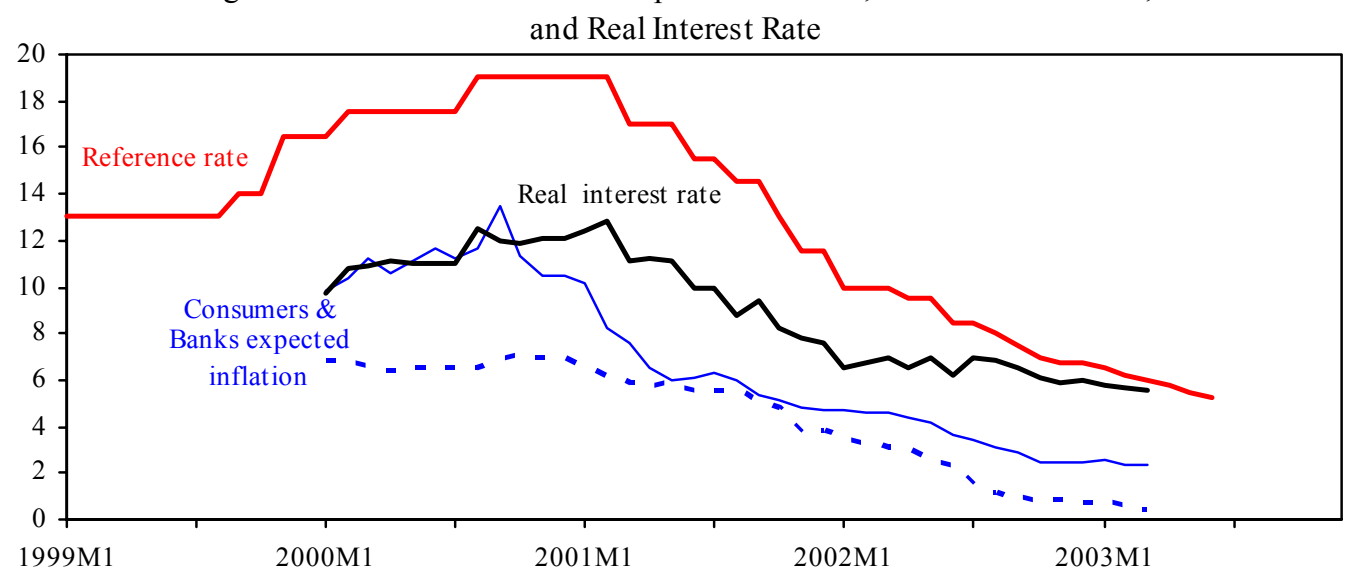

Figure 3. Exchange Rate, year-on-year percentage change

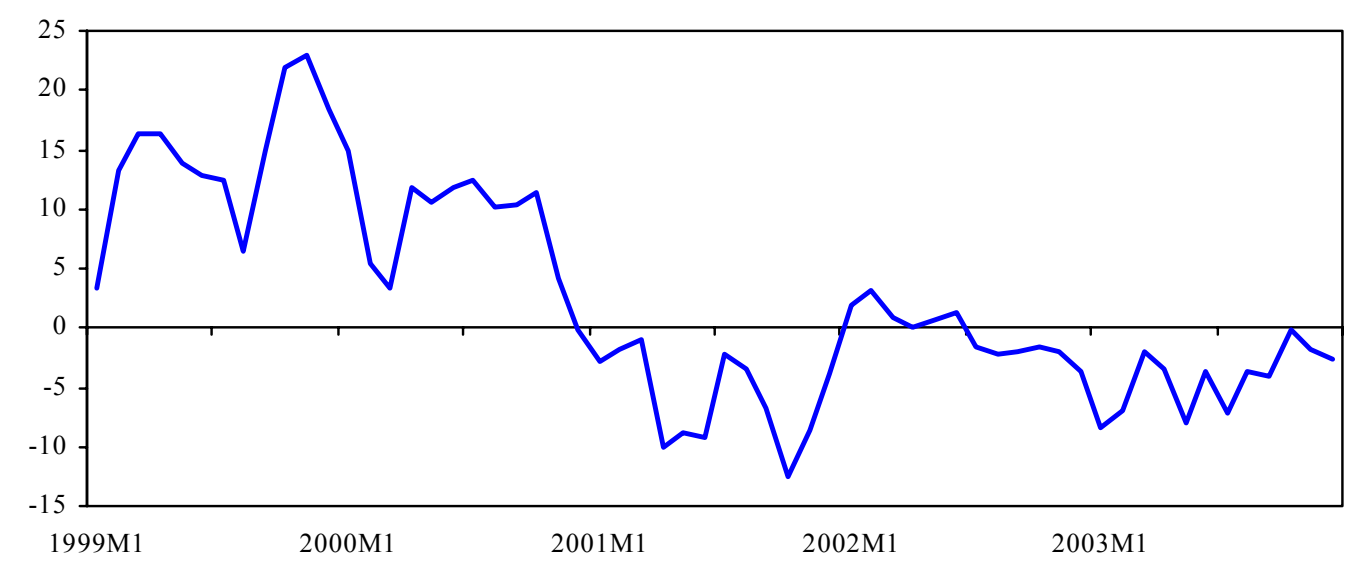

Source: National Bank of Poland, IFS. 
South Africa: 2001-2004

Figure 1. Target Inflation, Lower and Upper Band of Inflation Target

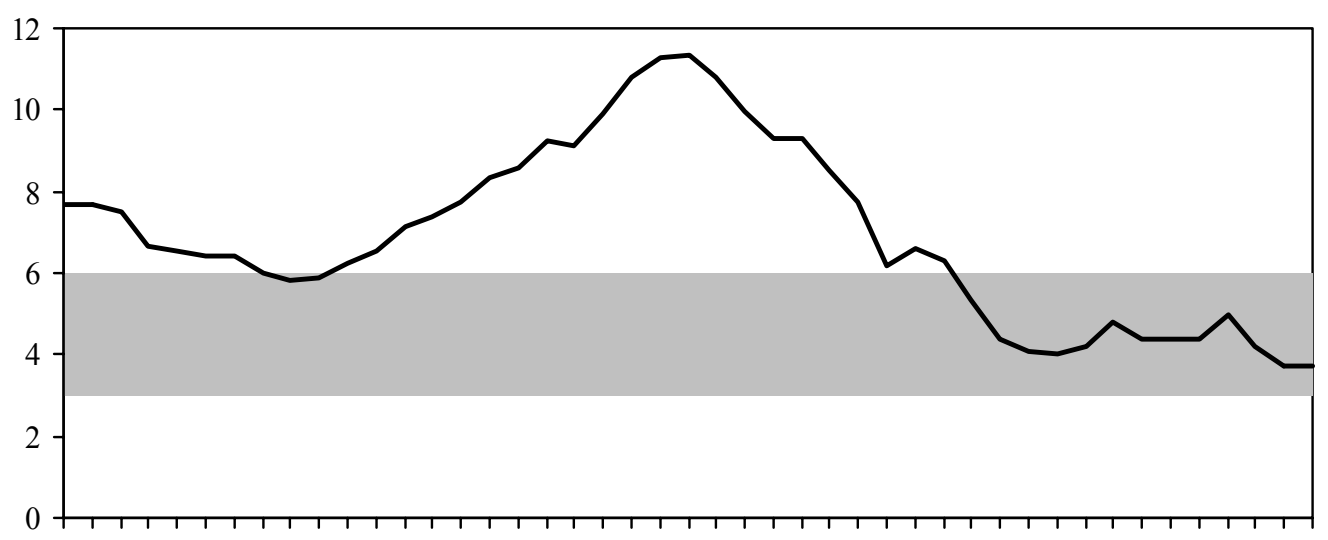

2001M1 2001M5 2001M9 2002M1 2002M5 2002M9 2003M1 2003M5 2003M9 2004M1 2004M5 2004M9

Figure 2. Expected Inflation and Interbank Call Rate

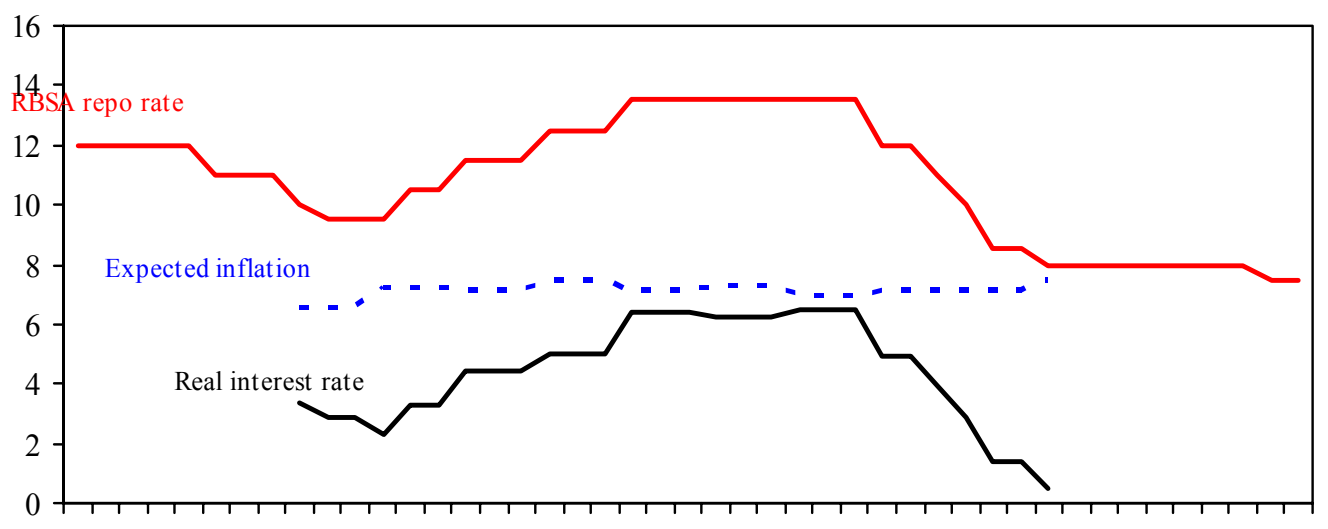

2001M1 2001M5 2001M9 2002M1 2002M5 2002M9 2003M1 2003M5 2003M9 2004M1 2004M5 2004M9

Figure 3. Exchange Rate, year-on-year percentage change

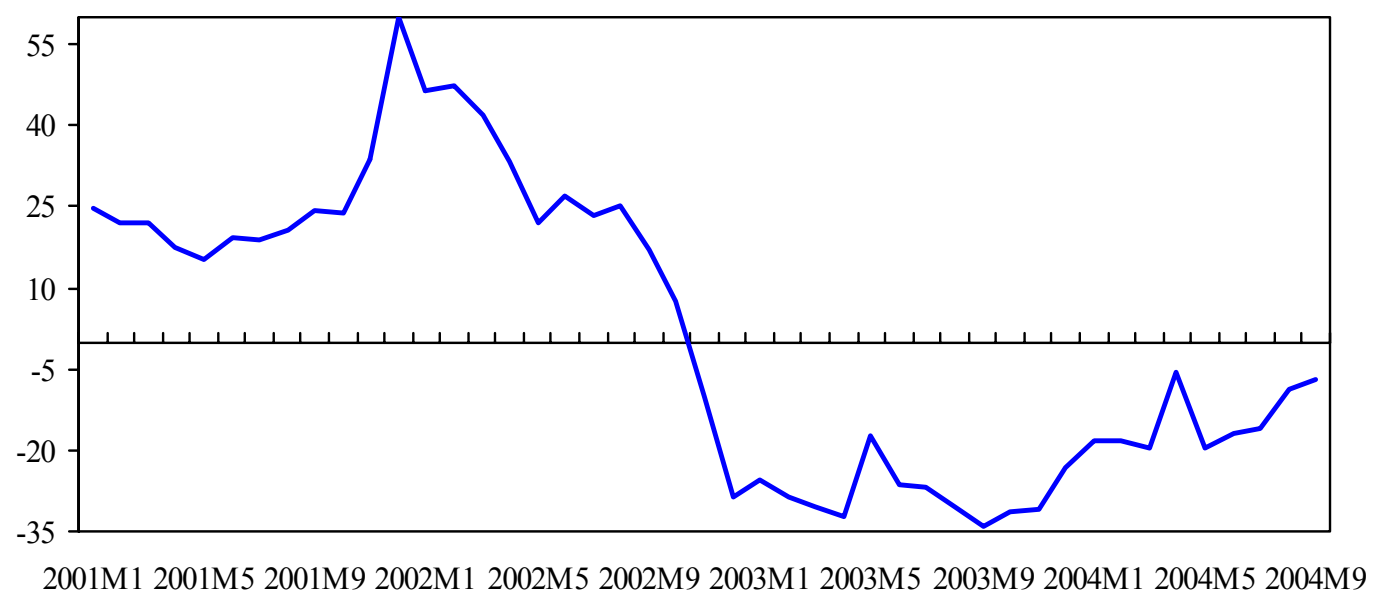

Source: South African Reserve Bank. 


\section{REFERENCES}

Almeida, A., and C. Goodhart, 1998, "Does the Adoption of Inflation Targets Affect Central Bank Behaviour?" Monetary Policy and Inflation in Spain, ed. by Malo de Molina and others (New York: St. Martin's Press), pp. 56-125.

Ball, L., and N. Sheridan, 2003, “Does Inflation Targeting Matter?” NBER Working Paper 95/77 (Cambridge, Massachusetts: National Bureau of Economic Research).

Bank of Canada, 1998, Price Stability, Inflation Targets, and Monetary Policy: Proceedings of a Conference Held by the Bank of Canada May 1997 (Ottawa: Bank of Canada).

Borio, C., 1997 "The Implementation of Monetary Policy in Industrial Countries: A Survey," Bank for International Settlements Economics Paper 47 (Basel: Bank for International Settlements).

Bernanke, B., T. Laubach, F. Mishkin, and A. Posen, 1999, Inflation Targeting: Lessons from International Experience (Princeton: Princeton University Press).

Blejer, M., A. Ize, A. Leone, and S. Werlang, (eds.), 2000, Inflation Targeting in Practice: Strategic and Operational Issues and Application to Emerging Market Economies, (Washington: International Monetary Fund).

Bubula, A. and I. Otker-Robe, 2002, "The Evolution of Exchange Rate Regimes Since 1990: Evidence From De Facto Policies,” IMF Working Paper 02/155 (Washington: International Monetary Fund).

Caballero, R., and A. Krishnamurthy, 2003, "Inflation Targeting and Sudden Stops" NBER Working Paper 95/99 (Cambridge, Massachusetts: National Bureau of Economic Research).

Carare, A., A. Schaechter, M. Stone, and M. Zelmer, 2002, "Establishing Initial Conditions in Support of Inflation Targeting," IMF Working Paper 02/102 (Washington: International Monetary Fund).

Carare, A. and M. Stone, 2005, "Inflation Targeting Regimes," European Economic Review, forthcoming.

Castelnuovo, E., S. Nicoletti-Altimari and D. Rodríguez-Palenzuela, 2003, "Definition Of Price Stability, Range and Point Inflation Targets: The Anchoring of Long-Term Inflation Expectations," ECB Working Paper 273 (Frankfurt: European Central Bank).

Clifton, E., 1999, "Inflation Targeting: What is the Meaning of the Bottom of the Band?" IMF Policy Discussion Paper 99/8 (Washington” International Monetary Fund). 
Corbo, V., O. Landerretche, and K. Schmidt-Hebbel, 2001, “Assessing Inflation Targeting After a Decade of World Experience," International Journal of Finance and Economics, Vol. 6, pp. 343-68.

Czech National Bank, 2000, Inflation targeting in transition economies: the case of the Czech Republic, edited by Warren Coats (Prague: Czech National Bank).

Debelle, G., and S. Fischer, 1994, "How Independent Should A Central Bank Be?” in Fuhrer, J., pp. 195-221.

Ferreira, T., and M. Petrassi, 2002, "Inflation Targeting: An Analysis of International Experience," Banco Central do Brazil Technical Notes 30.

Fraga, A., I. Goldfajn and A. Minella, 2003, "Inflation Targeting in Emerging Market Economies," Banco Central do Brasil Working Paper 5.

Fry, M., D. Julius, L. Mahadeva, S. Roger and G. Sterne, 2000, "The Use of Explicit Targets for Monetary Policy: Practical Experiences in 93 Countries in the 1990s," in Mahadeva and Sterne, pp. 29-56.

Fuhrer, J., (ed.), 1994, Goals, Guidelines, and Constraints Facing Monetary Policymakers, (Boston: Federal Reserve Bank of Boston).

Goldfajn, I. and S. Werlang, 2000, "The Pass-through from Depreciation to Inflation: A Panel Study," Banco Central do Brasil Working Paper 5.

Gómez, J., J. Uribe, and H. Vargas, 2002, “The Implementation of Inflation Targeting in Colombia," Central Bank of Colombia Borradores de Economía 202.

Haldane, A., (ed.), 1995, Targeting Inflation, (London: Bank of England).

Ho, C., and R. McCauley, 2003, "Living with Flexible Exchange Rates: Issues and Recent Experience in Inflation Targeting Emerging Market Economies," BIS Working Paper 130.

Hu, Y., 2003, "Empirical Investigations of Inflation Targeting," Institute for International Economics, Working Paper 03-6.

International Monetary Fund, 2005, Selected Country Experiences in Implementing the Code of Good Practices on Transparency in Monetary and Financial Policies.

Johnson, D.,1998, “The Credibility of Monetary Policy: International Evidence Based on Surveys of Expected Inflation" in Bank of Canada (1998), pp. xx. 
Jonas, J. and F. Mishkin, 2003, "Inflation Targeting in Transition Countries: Experience and Prospects," NBER Working Paper 9667.

Landerretche, O., V. Corbo and K. Schmidt-Hebbel, 2001, "Does Inflation Targeting Make a Difference?" Central Bank of Chile Working Paper 106.

Lane, P., G. Milesi-Ferretti, 2003, "International Financial Integration," IMF Staff Papers, 50, Special Issue:82-118 (Washington).

Leeper, E., 2003, “An ‘Inflation Reports’ Report,” NBER Working Paper 10089.

Leiderman, L. and H. Bar-Or, 2002, "Monetary Policy Rules and Transmission Mechanisms under Inflation Targeting in Israel," in Loayza and Schmidt-Hebbel, 2002, pp. 393-425.

Leiderman, L. and G. Bufman, 2000, "Inflation Targeting Under a Crawling Band Exchange Rate Regime: Lessons from Israel,” in Blejer and others, 2000, pp. 70-79.

Loayza, N., and K. Schmidt-Hebbel, (eds.), 2002 Monetary Policy: Rules and Transmission Mechanisms, (Santiago: Central Bank of Chile).

Mahadeva, L., and G. Sterne, (eds.), 2000, Monetary Frameworks in a Global Context, (London: Routledge).

Marques, C., P. Neves, and A. da Silva, 2000, "Why should Central Banks avoid the use of the underlying inflation indicator?" Bank of Portugal Working Paper 5-00.

Malo de Molina, M., J. Viñals and F. Gutiérrez, (eds.), 1998, Monetary Policy and Inflation in Spain, (New York: St. Martin's Press).

Marques, C., 2004, “Inflation Persistence: Facts or Artifacts?” Bank of Portugal Working Paper 8-04.

Masson, P., M. Savastano, and S. Sharma, 1997, “The Scope for Inflation Targeting in Developing Countries," IMF Working Paper 97/130.

Mishkin, F., 1999, "International Experiences with Different Monetary Policy Regimes," Journal of Monetary Economics, Vol. 43, pp. 579-605.

— , 2000, "Inflation Targeting in Emerging Market Countries," NBER Working Paper 7618.

_, $2004 \mathrm{a}$, “Can Inflation Targeting Work in Emerging Market Countries?” NBER Working Paper 10646. 
_, $2004 b$, “Can Central Bank Transparency Go Too Far?” NBER Working Paper 10829.

— What do We Know and What do We Need to Know?" NBER Working Paper 8397.

Morandé, F., 2001, “A Decade of Inflation Targeting in Chile: Developments, Lessons, and Challenges," Central Bank of Chile Working Paper 115.

Nadal de Simone, F., 2001, “An Investigation of Output Variance Before and During Inflation Targeting," IMF Working Paper No. 01/215.

Rankin, R., 2001, “The Exchange Rate and the Reserve Bank's Role in the Foreign Exchange Market" (Sydney: Reserve Bank of Australia).

Roger, S., 1998 “Core inflation: Concepts, Uses and Measurement," Reserve Bank of New Zealand Discussion Paper 98/9.

Schaechter, A., M. Stone, and M. Zelmer, 2000, “Adopting Inflation Targeting: Practical Issues for Emerging Market Countries," IMF Occasional Paper 202.

Schmidt-Hebbel, K., and M. Tapia, 2002, "Monetary Policy Implementation and Results in Twenty Inflation-Targeting Countries," Central Bank of Chile Working Paper 166.

Stevens, G., 2003, "Inflation Targeting: A Decade of Australian Experience," Address to South Australian Centre for Economic Studies, April.

Stone, M., 2003, “Inflation Targeting Lite,” IMF Working Paper 03/12.

— Paper 04/191.

Svensson, L., 2000, “Open-Economy Inflation Targeting,” Journal of International Economics, Vol. 50: 155-183.

—_, 2003, “Monetary Policy and Real Stabilization,” NBER Working Paper 9486.

— 2005, "Further Developments of Inflation Targeting," presented at the Inflation targeting: implementation, communication and effectiveness workshop held at the Sveriges Riksbank, June.

Sveriges Riksbank, 2002, “The Riksbank’s Interventions in the Foreign Exchange MarketOperations, Decision-Making and Communication" (Stockholm: Sveriges Riksbank). 
Truman E., 2003, Inflation Targeting and the World Economy (Washington: Institute for International Economics).

Tuladhar, A., forthcoming, "Governance Structure and Decision Making Roles in Inflation Targeting Central Banks," IMF.

Woodford, Michael, 2005, "Central-Bank Communication and Policy Effectiveness" presented at the Inflation targeting: implementation, communication and effectiveness workshop held at the Sveriges Riksbank, June.

Wu, T., 2004, "Does Inflation Targeting Reduce Inflation? An Analysis for the OECD Industrial Countries," Banco Central do Brasil Working Paper 83.

Wyplosz, C., H. Genberg, and A. Fracasso, 2003, How Do Central Banks Write?, Geneva Reports on the World Economy Special Report 2, The Center for Economic Policy Research. 